\title{
How do trade union rights affect trade competitiveness?
}

\author{
Working Paper No. 39
}

\section{David Kucera and Ritash Sarna*}

\author{
Policy Integration Department \\ Statistical Development and Analysis Group \\ International Labour Office \\ Geneva
}

\begin{abstract}
March 2004
* Statistical Development and Analysis Group

and International Institute for Labour Studies, respectively.
\end{abstract}





\section{How do trade union rights affect trade competitiveness?}

Contents

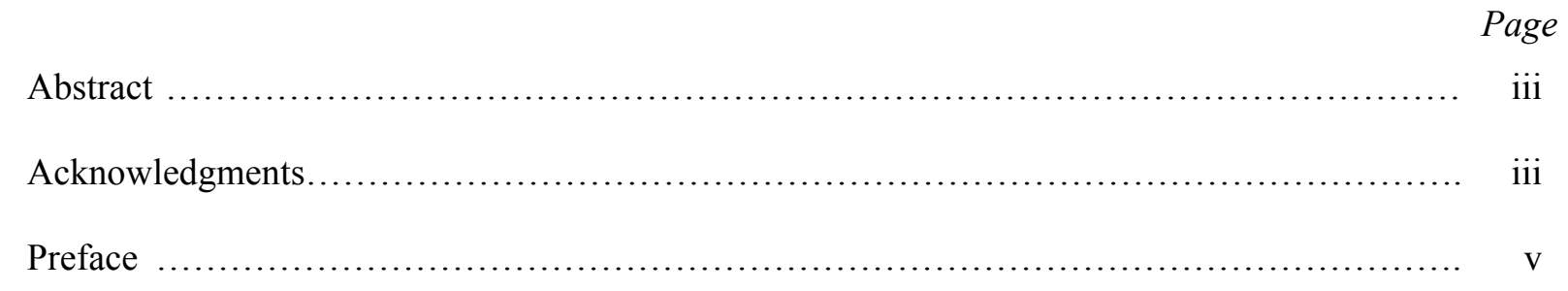

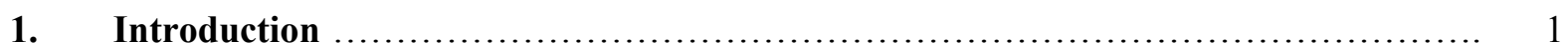

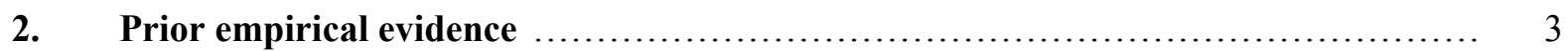

3. Indicators of freedom of association and collective bargaining rights and democracy 7

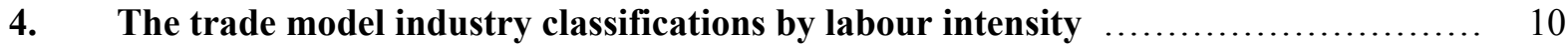

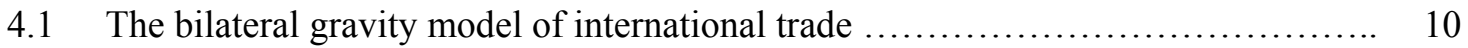

4.2 Industry classifications by labour intensity and benchmark model results ......... 13

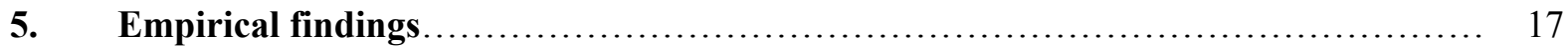

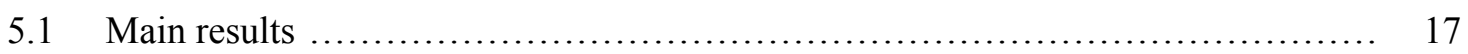

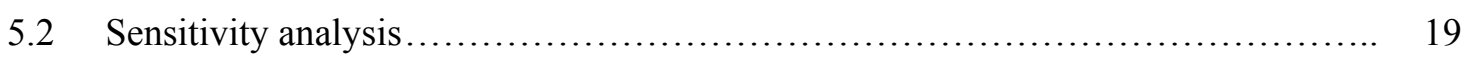

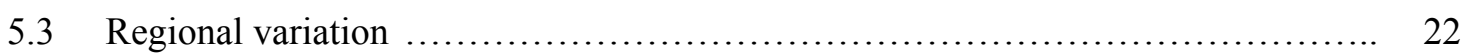

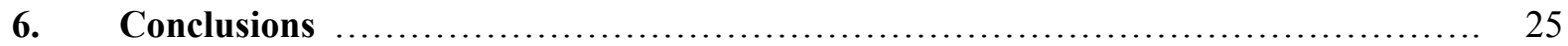

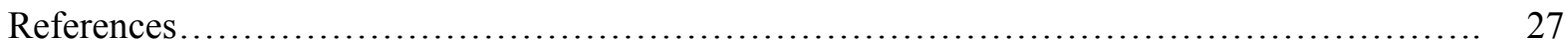

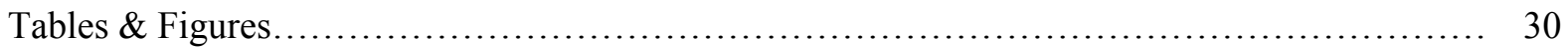

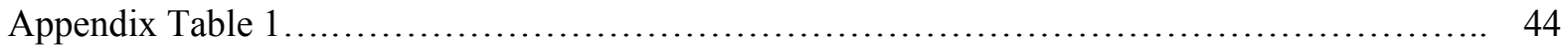

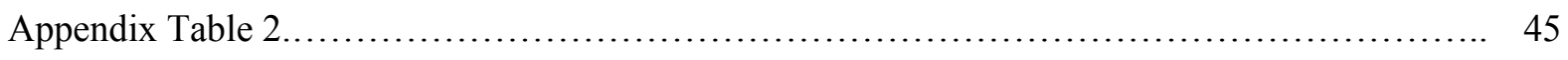

Appendix: Data Sources........................................................ 46

Appendix: Data Notes................................................................. 47 


\begin{abstract}
The paper uses a bilateral trade gravity model to evaluate the effects of freedom of association and collective bargaining (FACB) rights and democracy on exports, evaluating exports by labour intensity (using several classifications of industries by labour-intensity) for the 1993 to 1999 period. The model includes data for up to 162 countries and employs a number of indicators of FACB rights and democracy, including those constructed by the authors based on the coding of textual sources, the OECD FACB indices, the Freedom House civil liberties and political rights (democracy) indices, and "residual" versions of these indicators addressing the endogeneity of FACB rights and democracy with respect to trade openness. The paper finds robust relationships between stronger FACB rights and higher total manufacturing exports as well as between stronger democracy and higher total exports, total manufacturing exports and labour-intensive manufacturing exports. The paper finds no robust relationship between FACB rights and labour-intensive manufacturing exports.
\end{abstract}

\title{
Acknowledgments
}

For their helpful comments, the authors would like to thank Patrick Belser, Janine Berg, Gary Hufbauer, Robert Hutchens, Nomaan Majid, Jörg Mayer, Adrian Wood and Sylvester Young, as well as the participants of a research workshop held at the ILO in November 2003. We would also like to thank Jörg Mayer and Adrian Wood for providing us with their data on years of educational attainment and the staff of Statistics Canada for their helpful responses to our queries related to the "World Trade Analyzer" dataset. 


\section{Preface}

A key policy debate in the current wave of economic globalization is whether countries with higher labour standards are at a disadvantage with respect to international trade competitiveness, particularly for trade of labour-intensive goods. As old as this debate is, it has intensified in recent years alongside the expansion of trade in competing goods between countries having widely varying labour standards and also widely varying labour costs. This debate, though receiving much attention in both academic and policy circles, has unfolded amidst considerably less empirical evidence than one would hope for. A key bottleneck in developing such evidence has been the scarcity of indicators of labour standards, particularly indicators addressing trade union rights. Moreover, the trade and labour standards debate has tended to consider a narrow set of causal channels through which labour standards might affect trade competitiveness, focusing in particular on labour productivity and labour costs. The present study aims to make some headway in developing new empirical evidence on this debate, employing the authors' newly constructed "qualitative" indicators of violations of trade union rights in a broad sample of richer and poorer countries. The study finds that stronger trade union rights do not generally hinder trade competitiveness, including for trade of labour-intensive goods, and indeed that countries with stronger trade union rights tend to do comparatively well for manufacturing trade as a whole. The study comes to broadly similar findings using indicators of democracy and interprets them to result from the beneficial effects of stronger trade union rights and democracy on economic and social stability.

February 2004

Peter Peek

Manager

Statistical Development and Analysis Group Policy Integration Department 



\section{How do trade union rights affect trade competitiveness?}

\section{Introduction}

Freedom of association and collective bargaining (FACB) rights have figured prominently in the debate on the effects of labour standards on trade competitiveness, perhaps because these rights pose a particularly challenging set of questions. ${ }^{1}$ FACB rights have been classified as "civic rights" for workers and are in this sense akin to civil liberties and democracy (Portes 1994). In contrast with certain other labour standards, FACB rights define a process and their observance does not necessarily impose an immediate labour cost. It is reasonable to expect, though, that stronger FACB rights will tend to eventually give rise to higher labour costs even after accounting for labour productivity. For stronger FACB rights are likely to lead to higher unionization rates, and studies for different countries based on microeconomic data show that union members tend to receive higher wages than non-union members, even after accounting for a range of other productivityrelated determinants of wages (Freeman 1994). In addition, cross-country econometric studies using qualitative indicators of de facto democracy and FACB rights find that stronger rights by these measures are associated with higher manufacturing wages, even after accounting for other determinants of wages, labour productivity being the most important of these (Rodrik 1999; Belser 2001; Kucera 2001).

It is reasonable to expect, in turn, that higher labour costs would adversely affect trade competitiveness, particularly trade of labour-intensive goods. It is this line of argument that motivates much of the debate regarding the effects of FACB rights on trade competitiveness. Concern about the effects of labour standards on trade competitiveness has grown along with expanding trade between richer and poorer countries in competing goods, particularly trade in manufactures. From the viewpoint of richer countries, this is commonly expressed as a concern that expanding trade with poorer countries will create downward pressure on labour standards in richer countries as they endeavor to maintain their competitiveness. And worker rights and democracy do tend to be weaker in poorer countries, including (we will see) FACB rights. From the viewpoint of poorer countries, the concern is that strengthening labour standards will have a negative effect on trade competitiveness or that downward pressure on existing standards will result as countries with weaker standards enter more fully into international markets. This is of particular concern for poorer countries in the context of the Heckscher-Ohlin principle that a country's comparative trade advantage is determined by its relative factor endowments and that poorer countries tend to have high relative endowments of labour.

The trade and labour standards debate has tended to focus more on the labour cost effects and less on non-labour cost effects of FACB rights. However non-labour cost effects of FACB rights may be of considerable importance in promoting trade competitiveness. In particular, stronger democracy and FACB rights may tend to be associated with greater economic and social stability that facilitates trade competitiveness and economic performance more generally. For example, Rodrik provides cross-country empirical evidence that: "1. Democracies yield long-run growth rates that are more predictable. 2. Democracies produce greater stability in economic performance. 3 . Democracies handle adverse shocks much better" (1997, pp. 2-3). Along these same lines,

\footnotetext{
${ }^{1}$ Some publications providing particularly useful critical insights into these debates are Brown, Deardorff and Stern (1996), Brown (2000), Ghose (2003), Rodrik (1996) and Sengenberger (2002).
} 
if one looks at the correlation between qualitative indicators of de facto democracy and FACB rights and country credit risk indices, one finds that stronger democracy and FACB rights are associated with lower country credit risk, which one might also expect to facilitate economic performance and trade competitiveness. ${ }^{2}$ Another possible causal channel is through foreign direct investment (FDI). For surveys of managers of multinational firms indicate that these managers generally rate political and social stability as a more important determinant of FDI location than labour costs, and multinational firms tend to export more and there is evidence that their presence leads to higher exports of domestic firms by facilitating access to world markets (Hatem 1997; Hanson 2001).

The perception that developing countries with greater trade competitiveness tend to have weaker FACB rights may result from the greater visibility of exports from these countries. Most obvious are the competitive successes of a number of East Asian countries having comparatively weak FACB rights. In order to know, though, whether there is a general association between weaker FACB rights and greater trade competitiveness, one must also include in one's purview countries with weaker FACB rights whose exports are less visible because they are not well integrated into international markets. That is, one must evaluate a representative sample of countries, especially given that there exist marked regional patterns of strength of FACB rights and trade competitiveness. This suggests the potential value of cross-country econometric studies of the determinants of trade competitiveness, evaluating as full a sample of countries as possible.

There have been in recent years several useful studies of this nature. This paper seeks to contribute to this growing body of literature, employing a cross-country bilateral trade gravity model evaluating data for up to 162 countries or regions for the 1993 to 1999 period. We evaluate trade with breakdowns by the labour intensity of production using four different classifications of labour-intensive manufacturing industries. We use several different indicators of FACB rights, including those of our own design and construction based on the coding of textual sources and addressing thirty-seven types of violations of FACB rights, as well as FACB indices created by the OECD. We also use the Freedom House indices of civil liberties and political rights, which have been widely used in empirical work on the economics of democracy.

The paper is structured as follows. Section 2 surveys prior cross-country econometric studies addressing the effects of FACB rights on international trade. Section 3 describes the indicators of FACB rights and democracy that we use in our study, which overlap to some extent with those used in prior studies. Section 4 describes the bilateral trade gravity model and industry classifications by the labour intensity of production. Section 5 presents empirical results based on different industry classifications, with and without regional dummy variables, accounting for the endogeneity of FACB rights with respect to trade openness, and based on various other types of sensitivity analysis. It also addresses the regional variation of results. Section 6 concludes.

\footnotetext{
${ }^{2}$ For instance, the correlation coefficients (Pearson) between the Institutional Investor country credit risk index and the Freedom civil liberties and an FACB index (weighted) of our own construction are 0.61 and 0.41 , respectively, for the mid-1990s based on the full sample of countries for which such data are available, with higher values of the Institutional Investor index meaning lower country risk and with the civil liberties and FACB indices defined below.
} 


\section{Prior empirical evidence}

In this survey of prior empirical evidence, we focus on studies employing indicators related to FACB rights and democracy in econometric trade models and addressing trade between richer and poorer countries. Five such studies were of particular interest: Rodrik (1996), Belser (2001), Busse (2001), Flanagan (2003) and Maskus (2003). ${ }^{3}$

Rodrik (1996). Rodrik constructs a trade model with the ratio of textile and clothing exports to other exports (excluding fuels) as the dependent variable using data for the mid1980s and with samples of up to eighty-four countries. ${ }^{4}$ The two independent variables used in the benchmark model are the population-to-land ratio and average years of education for the population over twenty-five year of age, measures of relative labour endowments and human capital, respectively. Into this benchmark model are introduced (one at a time, in Rodrik and also in the following studies unless noted otherwise), four variables related to FACB rights: the number of core ILO Conventions ratified, the Freedom House democracy index, and the number of union members as a percentage of the labour force. ${ }^{5}$ For full samples of countries as well as for samples excluding richer countries, none of the above indicators of FACB rights are close to being statistically significant (no $t$-statistics on the above coefficient estimates exceed one in value). Nonetheless, for all indicators the signs of the coefficient estimates are consistent with the view that stronger FACB rights are associated with lower ratios of textile and clothing exports to other exports.

Belser (2001). Belser constructs trade models with the ratio of trade (exports plus imports) to GDP as the dependent variable using data for the first half of the 1990s and with samples of up to sixty-one countries. Belser breaks down trade into four categories by total trade, manufacturing trade, less skilled labour-intensive manufacturing trade and skill-intensive manufacturing trade. The latter two categories were constructed by Wood and Mayer (1998). Belser uses in his benchmark model GDP per capita and population. Additional model specifications include a dummy variable for openness and, for the last three trade categories, the adult population-to-land ratio and the average years of education for the population over fifteen year of age. Into these models are introduced a modified version of the OECD FACB index (described in section 3), converted to a dummy variable such that 0 equals countries with weaker FACB rights and 1 equals the opposite. For these four trade categories and the various model specifications, Belser finds that stronger FACB

3 Other empirical studies of interest are OECD (1996) and OECD (2000), which evaluate relationships between their FACB indices (described in the following section) and world export shares or export prices by various industry breakdowns via scatterplots and correlation coefficients; Mah (1997) which evaluates the relationship between the ratification of core ILO Conventions and the ratio of total exports to GDP, sometimes as a bivariate econometric relationship and sometimes controlling for real interest rates; and Van Beers (1998), which evaluates various OECD indicators, including those for "employees' representation rights," and exports broken out by labour intensity and skills intensity in a bilateral gravity model addressing trade only among OECD countries.

${ }^{4}$ With sample size for all studies surveyed here determined upon inclusion of at least one of the FACB rights or democracy indicators.

${ }^{5}$ Rodrik considers six ILO Conventions in this regard: 29, 87, 98, 105, 111 and 138. As with the core ILO Conventions considered by the other studies surveyed herein, these pertain to freedom of association and collective bargaining rights, discrimination in employment, forced labour and child labour. The democracy index is the average of the Freedom House civil liberties and political rights indices, which are described in section 3. 
rights are associated with lower trade to GDP ratios. With the exception of skills-intensive manufacturing trade, the coefficient estimates on the modified OECD index are also statistically significant. Belser also finds that stronger FACB rights by this indicator are significantly associated with lower ratios of less skilled labour-intensive to skill-intensive manufacturing exports and with lower ratios of less skilled labour-intensive to total manufacturing exports but that there is no statistically significant relationship with the ratio of skill-intensive to total manufacturing exports.

Busse (2001). Busse constructs a trade model with a ratio of less skilled labourintensive manufacturing exports to total manufacturing exports as the dependent variable using data for the late-1990s and with samples of up to eighty-two countries. ${ }^{6}$ Similar to Rodrik, the two independent variables used in the benchmark model are the labour forceto-land ratio and an educational attainment index, based on the literacy rate and the average years of education for the population over twenty-five years of age. Into this benchmark model are introduced three variables related to FACB rights: the number of core ILO Conventions ratified, the Freedom House civil liberties index, and the OECD index of FACB rights. $^{7}$ As with Rodrik's study, the coefficient estimate on the number of core ILO Conventions ratified is not close to statistically significant, but it is of opposite sign (positive in this case). Busse does find, though, strongly significant coefficient estimates on the Freedom House civil liberties index and the OECD index, suggesting that stronger FACB rights are associated with lower ratios of less skilled labour-intensive to total manufacturing exports.

Flanagan (2003). Flanagan constructs a trade model with the ratio of total exports to GDP as the dependent variable using data for the first half of the 1980s and with samples of up to seventy-eight countries. Similar to the above studies, Flanagan uses in his benchmark model the population-to-land ratio and the average years of education for the population over twenty-five year of age. In addition, he includes in his benchmark model a measure of the change in the terms of trade for merchandise, a measure of the average distance to the capital cities of countries with the largest exports, and dummy variables for openness, being an island and being landlocked. Into this benchmark model are introduced three indicators related to FACB rights: the number of core ILO Conventions ratified at the beginning of the period, a "predicted" form of this indicator based on a number of possible determinants of ratification, and the Freedom House civil liberties index ${ }^{8}$

Regarding the number of core ILO Conventions ratified and the "predicted" form of this indicator, the sign on the corresponding coefficient estimates is negative for the former and positive for the latter, though neither is statistically significant. (Flanagan comes to the same basic finding using two analogous indicators of non-core ILO Conventions.)

\footnotetext{
${ }^{6}$ These industries are textile yarn and fabrics (SITC Rev. 3, 65), glass, glassware and pottery (664666), furniture and bedding (82), travel goods and handbags (83), apparel (84), footwear (85) and baby carriages, games, toys and sporting goods (894), with the classification by skills from the OECD (2001) and the classification by labour intensity, based on value added per worker, from Tyres, Phillips and Findlay (1987).

${ }^{7}$ Busse considers eight ILO Conventions in this regard: 29, 87, 98, 100, 105, 111, 138 and 182. Note that Convention 182 came into effect only in the year 1999.

${ }^{8}$ Flanagan considers the same eight ILO Conventions as does Busse in this regard. Regarding the "predicted" form of these indicators, measures of the determinants of ratification are the economic activity rate of ten to fourteen year olds, the Freedom House civil liberties index, life expectancy (with these three taken as indicators of actual labour conditions), total trade relative to GDP, and dummy variables for the predominant religion and legal system of a country.
} 
Flanagan finds a coefficient estimate on the civil liberties index that is not close to being statistically significant, though the sign of the estimate (introducing the variable along with two other indicators of actual labour conditions) is consistent with the view that stronger civil liberties are associated with lower total exports relative to GDP.

Maskus (2003). Maskus' study is based on a bilateral trade gravity model with labour-intensive manufacturing exports for five industries as the dependent variable using data for 1995 and 1999 (in separate models) and with samples of seventeen developing country exporters and twenty OECD country importers, yielding 1,700 observations. Into this model are introduced the OECD FACB index, an index of core labour standards constructed by the NGO Verité, and the number of core ILO Conventions ratified. ${ }^{9}$ Describing his main findings for the first two of these measures, Maskus writes, "the results suggest that bilateral export volumes in labor-intensive goods actually rise as worker protection is increased - a finding that is particularly true within East Asia" (p. 172). It is not obvious to us, however, that the results Maskus presents warrant this conclusion. This has to do with the construction of the model in which FACB indicators are included by themselves but also interacted with regional dummy variables for East Asia, South Asia and Latin America. Thus the positive coefficient estimates on the noninteracted FACB indicators refer only to the two exporting countries excluded from these regions, Egypt and South Africa. Maskus' results are also based on the simultaneous inclusion in the model of the Freedom House democracy index, which other authors take as an indicator of labour standards in its own right and which is quite highly correlated with the OECD FACB and Verité indices (Maskus 2003, p. 167). Regarding the democracy index, in all model specifications Maskus finds that stronger democracy by this measure is associated with significantly lower labour-intensive exports for the full sample of exporters. Given these difficulties in interpretation, we leave Maskus' study out of the subsequent summary.

Summarizing the above studies, of the three addressing the ratification of ILO standards, Rodrik, Busse and Flanagan, none find statistically significant evidence that ratification affects exports. Of the three studies employing the Freedom House indices, again Rodrik, Busse and Flanagan, the signs on coefficient estimates are consistent with the view that stronger rights negatively affects exports, though in Rodrik and Flanagan these estimates are not found to be near statistical significance. Both studies employing the OECD FACB index, Busse and Belser, find statistically significant results consistent with the view that stronger FACB rights negatively affect trade, particularly trade of less skilled labour-intensive goods. Regarding unionization rates, Rodrik finds a negative but not close to statistically significant relationship with labour-intensive exports.

There are two points worth noting regarding the above evidence. First, regarding the use of ratification of ILO Conventions as an indicator of labour standards, three of the above studies, Busse, Belser and Flanagan, provide evidence that ratification is weakly correlated with actual labour standards or is not a good predictor of actual labour standards. ${ }^{10}$ Thus it is not altogether clear what one should make of the non-results on coefficient estimates on the ratification of ILO Conventions. The present study focuses

\footnotetext{
${ }^{9}$ The five industries are ISIC 321, 322, 323, 324 and 390, defined in table 4.A. Maskus considers the same eight ILO Conventions as does Busse and Flanagan.

${ }^{10}$ Flanagan suggests an explanation for labour standards not being good predictor of actual labour standards, providing evidence that the ratification of ILO Conventions is "largely symbolic, reflecting previously attained labor conditions" (2002, p. 17).
} 
then not on ratification but on indicators addressing actual labour standards as regards freedom of association and collective bargaining rights, some of which take into account relevant national legislation and its application. Second, we will see below that the results on some of the indices used in the above studies, such as the OECD FACB indices, are quite sensitive to variations in model specification and to different classifications of labour-intensive manufactures, raising concerns about the robustness of these results.

\section{Indicators of freedom of association and collective bargaining rights and democracy}

This paper employs a number of indicators related to FACB rights. There are several reasons for this. The use of multiple indicators enables one to better address causal specificity - the ways in which different aspects of FACB rights might differently affect trade. The use of multiple indicators also provides a test of robustness as regards the different measurement errors to which different indicators are prone. The use of multiple indicators also facilitates looking for patterns of signs and statistical significance on coefficient estimates rather than relying more heavily on results for fewer indicators. Eight indicators related to freedom of association and collective bargaining (FACB) are used, six focusing more narrowly on FACB rights and two relating to democracy, in particular to civil liberties and political rights.

Unionization rate. ILO data on the number of union members as a percentage of the non-agricultural labour force. The unionization rate is a limited indicator of FACB rights as such, as there are a number of historical and structural determinants of the unionization rate having little to do with worker rights. Nonetheless, the measure provides a sense of the effect of unionization on trade competitiveness.

FH civil liberties index and FH political rights index. These indicators are created by Freedom House and provide a sense of the broader rights context within which worker rights are situated. ${ }^{11}$ Freedom House describes its rating method as follows: "The survey rates political rights and civil liberties on a seven-category scale, 1 representing the most free and 7 the least free. A country is assigned to a particular numerical category based on responses to the checklist and the judgments of the Survey team at Freedom House" (Freedom House 1999: 549).

Regarding the civil liberties index, the checklist referred to in the above quote consists of fourteen items in four categories: "freedom of expression and belief," "association and organizational rights," "rule of law and human rights" and "personal autonomy and economic rights." Under "association and organizational rights," one of the checklist items relates directly to FACB rights: "Are there free trade unions and peasant organizations or equivalents, and is there effective collective bargaining? Are there free professional and other private organizations?" Under the category "personal autonomy and economic rights," another checklist item refers to "freedom from exploitation" regarding employers and union leaders: "Is there equality of opportunity, including freedom from exploitation by or dependency on landlords, employers, union leaders, bureaucrats, or

${ }^{11}$ Freedom House is a non-profit organization based in the United States that describes itself as follows: "Non-partisan and broad-based, Freedom House is led by a Board of Trustees composed of leading Democrats, Republicans, and independents; business and labor leaders; former senior government officials; scholars; writers; and journalists" (www.freedomhouse.org). 
other types of obstacles to a share of legitimate economic gains?" The political rights index addresses questions relating to free and fair elections, the competitiveness of political parties, self-determination, and discrimination.

Approximately 120 publications and 120 organizations are consulted in creating these indicators. None of these are ILO publications and the ILO itself is not consulted.

The Freedom House indices are re-scaled to range from 0 to 10 , with 0 indicating the worst ("least free") and 10 the best ("most free") possible score.

Following the suggestion of Brown (2000), we also employ "residual" versions of these two indicators to address the endogeneity of FACB rights with respect to the extent of a country's trade openness as well as for the four following indicators, as explained in section 5.2 .

FACB index unweighted and FACB index weighted. These indicators of freedom of association and collective bargaining are based on thirty-seven evaluation criteria that address de jure as well as de facto problems, leaning in emphasis toward the latter. The thirty-seven evaluation criteria are based on ILO Conventions 87 ("Freedom of Association and Protection of the Right to Organise") and 98 ("Right to Organise and Collective Bargaining") and related ILO jurisprudence, as well as problems noted in textual sources. The indicators are constructed in unweighted (that is, equally weighted) and weighted form.

The method of construction consists of the following steps. First, three textual sources are examined, the International Confederation of Free Trade Unions' (ICFTU) Annual Survey of Violations of Trade Union Rights, the United States State Department's Country Reports on Human Rights Practices, and the ILO's Reports of the Committee on Freedom of Association. Problems found regarding the 37 evaluation criteria are then coded with letters "a," "b," or "c," indicating each of the different information sources, respectively. Next, a dummy variable is constructed for each country in which an observation of a problem in any of the three information sources is given a value of 1 and no observations in any of the three sources is given a value of 0 , for each of the thirty-seven evaluation criteria. For the weighted indicators, each of the evaluation criteria is assigned a weight of $1,1.25,1.5,1.75$ or 2 , with greater weights indicating more severe problems (based in part on the qualitative language used in the Reports of the Committee on Freedom of Association). Dummy variables for each country are then multiplied by the weights, and then this product is summed across the evaluation criteria to yield, for each country, a nonscaled raw score.

A hypothetical example of this method is illustrated in Table 3.A. Column A shows the thirty-seven evaluation criteria grouped by six categories: freedom of association and collective bargaining-related civil liberties; right to establish and join union and worker organizations; other union activities; right to collectively bargain; right to strike; and export processing zones. It should be emphasized that the descriptions of the thirty-seven evaluation criteria listed in column A are labels, not definitions. Each of the evaluation criteria are based on a detailed set of definitions and decision rules, indicating relevant ILO Convention articles and jurisprudence passages; how to classify the diverse range of problems noted in the information sources; and how the various evaluation criteria relate to each other (in terms of mutual exclusivity, how a single problem might imply more than one evaluation criteria, and so on). The aim is to have a sufficiently detailed set of 
definitions and decision rules that different evaluators would arrive at the same results. That is, the aim is reproducibility.

Column B shows the coding of problems according to the information source and column $\mathrm{C}$ the dummy variables derived from column $\mathrm{B}$. Within column $\mathrm{C}$, a look at the two shaded rows indicates a value in the dummy variable of 1 for both rows, even though problems were found in all three information sources for the upper row and only one source for the lower row. The rationale for treating both rows the same (rather than giving more weight to the upper) is to avoid double counting, for the different sources are often describing the same problem in a country. Indeed, the U.S. State Dept. reports are based in part on the ICFTU reports and information from the ILO, and the ICFTU reports are in turn based in part on information from the ILO.

Weights are shown in column D. Column E shows the product of the dummy and the weights, the sum of which yields the non-scaled weighted score for a given country. The non-scaled unweighted score is simply the sum of column C. ${ }^{12}$ (In spite of the differences in construction, the correlation coefficient between the unweighted and weighted indicators is 0.99 .) The non-scaled indicators are then rescaled to range from 0 to 10 , with 0 indicating the worst possible score (most violations observed) and 10 indicating the best (least violations observed) possible score. In addition, any country for which there are general prohibitions of the right to establish and join union and worker organizations (row 6), general absence of the above resulting from socio-economic breakdown (row 7), or general prohibitions of the right to collectively bargain (row 24) receive a default score of 0 .

OECD FACB index 1996 and OECD FACB index 2000. Based on ILO Conventions 87 and 98 and related ILO jurisprudence, the OECD indices are created from three tables with up to one paragraph of text on three aspects of FACB rights: "Restrictions on the right to establish free unions," "Restrictions on the right to strike" and "Protection of union members and collective bargaining rights." The main sources consulted are various ILO sources, the ICFTU Annual Survey of Violations of Trade Union Rights, and the United States State Department's Country Reports on Human Rights Practices. The OECD writes that "based on [OECD] Secretariat judgment," an overall score of 1, 2, 3 or 4 is given for each country based on text in the tables, with 1 indicating strongest rights and 4 indicating weakest rights (OECD 1996: 43). ${ }^{13}$ These indicators are constructed for the mid-1990s (OECD 1996) and the late-1990s (OECD 2000), and both are used in the

${ }^{12}$ There is also a difference in construction between weighted and unweighted indicators as regards the treatment of excluded sectors. It is assumed that there is a hierarchy of violations, such that the exclusion of a sector from union membership (rows 15 and 16) presupposes exclusion from collective bargaining (rows 29 and 30) which itself presupposes exclusion from the right to strike (rows 34 and 35). For the weighted indicators, weights are therefore greater for lower-numbered rows and, for example, if problems are found in rows 29 and 34, only row 29 was coded, since the higher weights of lower-number rows addresses the assumed hierarchy of violations. (This holds even if the violations noted in rows 29 and 34 are for different tradeable sectors.) The unweighted indicator also assumes this hierarchy of violations but in a different manner. Here, for instance, if a violation is only observed in row 29, both rows 29 and 34 are coded. In practical terms, these differences between weighted and unweighted indicators come to little, given that the correlation coefficient between the two indicators of 0.99 .

13 The ordering is reversed in OECD 2000. The OECD writes that "The rankings from the 1996 study were generally maintained, except that [South] Korea, Turkey and Indonesia were each advanced one group...", indicating that FACB rights improved for these three countries from the mid- to late-1990s (OECD 2000: 27). 
present study. The OECD indices are rescaled to range from 0 to 10 , with 0 indicating weakest rights and 10 indicating strongest rights. The OECD indices are constructed for both OECD and non-OECD countries but are nonetheless available for only about half as many countries as the Freedom House and our own indices, so it is worth bearing in mind that regression results using the OECD indices pertain to a substantially different sample of countries.

FACB in EPZs. This is a dummy variable for observations of FACB violations in export-processing zones (EPZs), with 1 indicating violations found and 0 indicating otherwise, and is based on the thirty-seventh row of Table 3.A, taken by itself.

For all the above indicators except FACB in EPZs, higher values are associated with stronger FACB rights, with the Freedom House, FACB and OECD indices normalized to range from 0 to 10 , weakest to strongest rights, to enable direct comparison of coefficient estimates on these variables.

Indicators of FACB rights are for the mid-1990s and are employed in cross-sectional trade models with countries as units of observation. More precisely, unionization rate data are for 1995 or the nearest available year. Freedom House indices are constructed as fiveyear averages for the 1993 to 1997 period. For the FACB indices constructed from coding textual information, events that occurred between 1993 and 1997 inclusive are coded. As noted, the OECD index is for the mid-1990s (OECD 1996) and the late-1990s (OECD 2000). In part, this cross-country approach results from information constraints for years prior to the mid-1990s for the indicators of worker rights newly constructed from coding textual sources. In short, much of the textual information used to construct these indicators is considerably sketchier for earlier years, when existent at all. The unionization rate and the OECD indices are also not available as time series. However, cross-country models may also be preferable to, for instance, fixed-effects models, given the ineluctable measurement error associated with such qualitative indicators and the particular sensitivity of fixed-effects models to measurement error.

Correlation coefficients (Pearson) among the above indicators, along with annual average GDP per capita from 1993 to 1997 in current US dollars and in current PPP international dollars, are shown in table 3.B. ${ }^{14}$ Note the positive correlations among the six main qualitative indicators of FACB rights and democracy in rows 4 to 9 (with the correlations particularly strong between the Freedom House and OECD indices) and also that these indicators are similarly positively correlated with the unionization rate. Note also that for all of the indicators relating to FACB rights and democracy, stronger rights are associated with higher GDP per capita. Such a pattern is to be expected regarding labour standards for which there are clear income-related determinants, such as for child labour, but it is noteworthy that it also appears for FACB rights and democracy, which define a process that one might not necessarily expect to be related to per capita income.

Shown in table 3.C are various descriptive statistics for these same variables, including means, standard deviations, the number of observations per variable and the

\footnotetext{
${ }^{14}$ For the sake of assessing the statistical significance of these correlation coefficients, note that the critical two-tailed values for 100 degrees of freedom (98 observations) are $0.164,0.195$ and 0.254 at the 10,5 and 1 percent levels, respectively.
} 
number of countries per region. The regional breakdowns for mean values are useful in evaluating the impact of particular regions on overall results.

\section{The trade model and industry classifications by labour intensity}

\subsection{The bilateral gravity model of international trade}

We employ a bilateral gravity model to evaluate the relationship between FACB rights and international trade. It is referred to as a gravity model in analogy with the determinants of the strength of gravitational pull, in that the volume of trade between countries is hypothesized to be positively determined by a country's "mass" and negatively determined by the distance between countries. Rose describes the empirical success as well as multiple theoretical foundations of the gravity trade model as follows:

"The gravity model of international trade has a remarkably consistent (and thus, for economics, unusual) history of success as an empirical tool.... Indeed in their recent survey on the empirics of international trade, Leamer and Levinsohn (1995, p. 1384) describe the gravity model as having provided '...some of the clearest and most robust empirical findings in economics.'... While originally an entirely empirical model, the gravity model can now claim theoretical foundations. In fact, numerous theoretical aspirants have claimed the singular empirical success of the gravity model. These include: the 'Armington' model of nationally differentiated goods; models with increasing returns and monopolistic competition; models with national technological differences; 'reciprocal dumping' models of homogenous goods; and models with internationally varying factor endowments" (Rose 1999, p. 8).

The consistency of the gravity model with trade theory based on relative factor endowments and the Heckscher-Ohlin principle (and also other trade theories) is shown by Bergstrand (1989), Deardorff (1995) and Evenett and Keller (1998). This theoretical consistency is relevant for our study in that we evaluate not just total trade but manufacturing industry trade with breakdowns by the labour intensity of production. The suitability of the gravity model for our purposes is suggested, for instance, by our inclusion of independent variables for population and land area, which in the context of our specification provide identical controls for relative endowments of labour and land as Rodrik (1996) and Flanagan (2003).

Our study relies on Rose (1998) and Van Beers (1997) regarding model specification - for both core gravity and supplemental independent variables - as well as sensitivity analysis. We follow Van Beers (and differ from Rose) in taking as the dependent variable exports from one country to another (rather than total trade between pairs of countries as in Rose), and consequently independent variables are constructed, whenever it is meaningful to do so, in pairs for exporting and importing countries, including for indicators of FACB rights. We take this approach because, as with Van Beers, this better enables us to evaluate the relationship between labour standards in a country and that country's exports.

Our model basically refers to the 1993 to 1997 period. Exports are for the 1993 to 1999 period, providing a somewhat lagged response to independent variables and yielding 
a slightly better modelling fit. For bilateral trade data, we rely on the World Trade Analyzer database. ${ }^{15}$ Following the conventions of this database, we evaluate samples of up to 135 "countries," eight of which are in fact comprised of groups of countries or regions. Thus the full sample is actually made up of 162 countries or regions, for which there are discrete data for 135 (see Appendix: Data Notes). For the sake of expediency, we refer to these simply as "countries" or each as a "country" hereafter.

The equation for the benchmark trade model is:

$$
\log \left(\text { exports }_{x m}\right)=
$$

$$
\begin{aligned}
& c+\log \left(\text { distance }_{x m}\right)+\log (\text { GDP/cap } x)+\log \left(\text { GDP }_{\text {cap }}\right)+\log \left(\text { pop }_{x}\right)+\log \\
& \left(\text { pop }_{m}\right)+\log \left(\text { area }_{x}\right)+\log \left(\text { area }_{m}\right)+\text { common border }_{x m}+1 \text { landlocked }_{x m}+2 \\
& \text { landlocked }_{x m}+1 \text { island }_{x m}+2 \text { island }_{x m}+R T A_{x m}+{\text { exchange rate }(88-92)_{x m}+\varepsilon,}
\end{aligned}
$$

where $\log$ refers to the natural logarithm, c is a constant, $\varepsilon$ is an error term, $\mathrm{x}$ refers to the exporting country, $m$ refers to the importing country, and the definitions of the remaining variables are as follows, with the conventional expected signs of coefficient estimates on independent variables in parentheses.

exports $_{\boldsymbol{x} \boldsymbol{m}}=$ exports from country $\boldsymbol{x}$ to country $\boldsymbol{m}$, annual average for the 1993 to 1999 period in thousands of current US dollars.

distance $_{x m}=$ surface (great circle) distance between the geographic centers of countries $\boldsymbol{x}$ and $\boldsymbol{m}$ in miles (negative).

$\boldsymbol{G D P} /$ cap $_{\boldsymbol{x}}$ and $\boldsymbol{G D P} /$ cap $_{\boldsymbol{m}}=$ national income per person in country $\boldsymbol{x}$ and $\boldsymbol{m}$, annual average for 1993 to 1997 in current US dollars (positive for both).

$\boldsymbol{p o p}_{\boldsymbol{x}}$ and $\boldsymbol{p o p}_{\boldsymbol{m}}=$ population in country $\boldsymbol{x}$ and $\boldsymbol{m}$, annual average for the 1993 to 1997 period (positive for both).

Taken together with $\boldsymbol{G D P} / \boldsymbol{c a p}_{\boldsymbol{x}}$ and $\boldsymbol{G D P} / \boldsymbol{c a p}_{\boldsymbol{m}}, \boldsymbol{p o p}_{\boldsymbol{x}}$ and $\boldsymbol{p o p}_{\boldsymbol{m}}$ make up the measures of country "mass" and the four together with distance $_{x m}$ make up the core gravity model, with the remaining independent variables of a supplemental nature as regards the extent of work done in accounting for cross-country variation in trade.

$\boldsymbol{a r e a}_{x}$ and $\boldsymbol{a r e a}_{\boldsymbol{m}}=$ land area in square kilometers (negative for both).

common border $_{x m}=0$ if countries do not share a common border and 1 if they do (positive).

${ }^{15}$ The World Trade Analyzer database provides data only on gross exports, a potential limitation of which is pointed out by Jörg Mayer, who writes that "taking gross exports could be a problem because the data may be inflated by exports within international production networks that have a high import content and that may be produced in export processing zones with potentially different labour standard legislation than the rest of the economy" (personal correspondence). 
1 landlocked $_{x m}=1$ if one of the two countries is landlocked and 0 otherwise (negative).

2 landlocked $_{x m}=1$ if both of the countries are landlocked and 0 otherwise (negative).

1 island $_{x m}=1$ if one of the two countries is an island and 0 otherwise (positive).

2 island $_{x m}=1$ if both of the countries are islands and 0 otherwise (positive).

$\boldsymbol{R} \boldsymbol{T} \boldsymbol{A}_{x m}=0$ if countries are not in a regional trade agreement and 1 if they are (positive). ${ }^{16}$

exchange rate $(\mathbf{8 8 - 9 2})_{x m}=$ exchange rate volatility between country $\boldsymbol{x}$ and $\boldsymbol{m}$, constructed as the standard deviation of the monthly log growth rate of the bilateral exchange rate for the 1988 to 1992 period (negative). ${ }^{17}$

Main regressions are done with and without conventional regional dummy variables (in pairs with countries as both exporters and importers), for the sake of testing the robustness of results and facilitating comparison with previous studies. These regional dummy variables are for Latin America-Caribbean, non-OECD East Asia-Pacific (referred to as East Asia hereafter), South Asia, the transition countries, Sub-Saharan Africa, and Middle East-North Africa. The excluded region is for countries that were OECD members prior to 1990 (also applicable for the non-OECD East Asia-Pacific regional dummy variable). Coefficient estimates on the included regional dummy variables should be interpreted relative to this excluded region. Into these benchmark models are then introduced, one at time, the eight different indicators of FACB rights, in pairs for exporting and importing countries, with a particular interest in testing the hypothesis that stronger FACB rights in a country are associated with lower exports from that country. ${ }^{18}$

${ }^{16}$ This includes all types of regional trade agreements as of March 2001except those for services. In addition to this variable was tested a variable for tariffs for exporting and importing countries, defined as import duties as a percentage of imports. However this variable was missing for many countries in our sample and so reduced the number of observations by roughly half. For total trade and total manufacturing trade, moreover, the coefficient estimate on tariffs for importing countries was not statistically significant, and it is these tariffs that are expected to have the most direct impact on exporting countries.

${ }^{17}$ Exchange rates are given against the US dollar in the IMF International Financial Statistics, which we convert to bilateral form. In addition to the 1988 to 1992 period, we also tested this same variable constructed for the 1993 to 1997 period and found that its coefficient estimate was not statistically significant.

${ }^{18}$ In addition to the conventional hypothesis that stronger FACB rights in a country hinder its exports, Van Beers hypothesizes that stronger worker rights in an importing country would lead to higher imports into that country on the grounds that this will lead to higher wages and thus greater consumer demand for imports (1998). In this sense, Van Beers hypothesizes opposite signs on coefficient estimates on indicators of worker rights for the exporting and importing country. From the viewpoint of an importing country, however, such an effect might be offset by the higher marginal propensity to import from profits and other non-wage earnings. 
Rather than using GDP per capita and population as paired measures of country "mass," one could also use GDP per capita and GDP, as in Rose (1999), or GDP and population, as in Van Beers (1998). ${ }^{19}$ We prefer our specification on the grounds that GDP per capita and population are the least correlated of the three possible pairs and provide intuitively additive elasticities with respect to trade flows. That is, export and import potential are positively determined by the number of persons in a country plus the average domestic product (regarding exports) or income (regarding imports) per person in a country (though coefficient estimates on these variables lend themselves to different theoretical interpretations (Bergstrand 1989; Deardorff 1995; and Evenett and Keller 1998)). Practically speaking, however, it makes no difference in this particular context which pair one chooses, as any pair yields very near identical coefficient estimates and standard errors on all other independent variables in the model.

One could also substitute for the natural logarithm of land area the natural logarithm of the ratio of population to land area, as per Rodrik (1996) and Flanagan (2003) (and similar to Belser (2001) and Busse (2001)). Doing so yields coefficient estimates of identical magnitude but opposite sign between these variables, slightly smaller coefficient estimates on $\log \left(\boldsymbol{p o p}_{x}\right)$ and $\log \left(\boldsymbol{p o p}_{m}\right)$, and identical coefficient estimates on all other variables. As such, reversing the sign on $\log \left(\boldsymbol{a r e a}_{x}\right)$ in our specification provides an estimate of the effect of relative endowments of labour to land on exports. For manufacturing trade with breakdowns by labour intensity, these coefficient estimates turn out to be consistent with the Heckscher-Ohlin principle, as will be noted.

Econometric results are based on ordinary least squares, Tobit and weighted least squares estimation, with standard errors derived using White corrections except for Tobit estimation for which we use Huber/White corrections. Problematic collinearity was tested by the construction of variance inflation factors (VIF) and model specifications were tested with the Ramsey RESET specification error test. The benchmark model passes the VIF test at conventional thresholds, but results are mixed regarding the Ramsey RESET test. ${ }^{20}$ Results reported are coefficient estimates and significance symbols (two-tailed, with *, **, and $* * *$ indicating significance at 10,5 , and 1 percent levels, respectively), and - for benchmark regressions only - t-statistics on coefficient estimates, the number of observations ("N" in tables), adjusted $R^{2}$ s, and $F$-statistics.

\subsection{Industry classifications by labour intensity and benchmark model results}

We evaluate trade with breakdowns for total trade, total manufacturing trade, and, within manufacturing, for labour-intensive, capital-intensive and in-between industries. In the World Trade Analyzer database, total trade differs from manufacturing trade mainly in that it includes primary goods - that is, agricultural goods and non-agricultural raw materials.

\footnotetext{
${ }^{19}$ In which case the expected signs of coefficient estimates on population are argued by Van Beers to be negative, on the grounds that "a country with a large population can much easier specialize in a wide range of commodities and, consequently, will be less dependent on foreign trade" (Van Beers 1997, p. 64).

${ }^{20}$ Evaluating total trade with just the core variables of $\log \left(\right.$ distance $\left._{x m}\right), \log \left(G D P / c a p_{x}\right), \log$ $\left(G D P /\right.$ cap $\left._{m}\right), \log \left(\boldsymbol{p o p}_{x}\right), \log \left(\boldsymbol{p o p}_{m}\right)$ and with one fitted term for the RESET test yields an $F$-statistic of 2.240 with a probability of 0.134 . However, evaluating total manufacturing trade in the same manner yields an $F$-statistic of 15.939 with a probability of 0.000 . More fully specified models of total trade and total manufacturing trade yield similarly high $F$-statistics.
} 
Within manufacturing, regressions rely largely on industry classifications by labour intensity of our own construction. We classify manufacturing industries into labourintensive, capital-intensive and in-between industries, which sum to the manufacturing total. This was done as follows. Labour coefficients were created as five-year annual averages for the 1993 to 1997 period for those countries or regions that were the largest merchandise exporters and importers as of 1995 and for which there were no problems with the availability of data. We focus on these countries as it is their experience that provides the clearest sense of what it takes to be successful in international goods markets. This yielded a group of twenty-nine countries or regions. The labour coefficients were constructed largely at the three-digit ISIC (International Standard Industrial Classification) Rev. 2 level using the UNIDO Industrial Statistics Database. The exception is that we created a separate industry that combines office, computing and accounting machinery (ISIC 3825) and radio, television and communication equipment (ISIC 3832), as these goods figure importantly in exports from developing to developed countries. We rank these twenty-nine industries by taking the average ordinal ranking of labour coefficients across countries. For the main regressions, we classify the top nine industries as labour-intensive, the middle eleven as in-between, and the bottom nine as capital-intensive. ${ }^{21}$

This method yields what seem to be reasonable industry classifications, shown in table 4.A. Labour-intensive industries are similar to those characterized as such by other studies and include the needle trades and other light manufacturing for which the product can generally be readily conveyed by hand (cf. Cutler, Berri and Ozawa (2003) for an overview of previously-used classifications of labour-intensive manufacturing industries). Most fundamentally regarding the debates on trade and labour standards, all industries classified as labour-intensive are those for which there do not appear to be prohibitive technological barriers preventing poorer developing countries from competing in international goods markets, at least for many types of products within each of these industries. This is in general contrast with industries we have classified as capital-intensive or in-between. All industries categorized as capital-intensive are those for which the product lends itself to production by highly automated "continuous-process" technologies

${ }^{21}$ The list of largest merchandise exporters and importers is from The Economist Intelligence Unit's World Trade Report (EIU, 1996), which treats the EU 15 as a single unit. The countries or regions used to construct industry rankings are Australia, Brazil, Austria, Canada, China, Denmark, Finland, France, Greece, Hong Kong (China), Indonesia, Ireland, Italy, Japan, Malaysia, Mexico, Netherlands, Norway, Portugal, Russia, Singapore, South Korea, Spain, Sweden, Taiwan (China), Thailand, Turkey, the United Kingdom and the United States Data are also available for Germany, India and Saudi Arabia, but the first two were excluded because their labour coefficients tended to be weakly correlated with those of other countries or regions and Saudi Arabia was excluded because of its high share of oil exports. Data for Australia are from 1992, as these data were not available for the 1993 to 1997 period. Turkey is the only country of the twenty-nine that is on the importer list but not the exporter list.

We constructed industry classifications both by employment to value added ratios and employment to output ratios. In practice, the difference between the two classifications comes to little. Most importantly, the labour-intensive industry group remains identical. The only difference in the other industry groups is that food products and paper and paper products move in opposite directions from capital-intensive to in-between industries depending on which ratio is used. However, we have a slight preference for the use of employment to output ratios and so use these as the basis of industry classifications. This better groups like industries alike (food products with beverages and tobacco products in capital-intensive industries; paper and paper products with printing and publishing in in-between industries) and to some extent addresses comparative advantage based not only on relative factor endowments, as per the Heckscher-Ohlin principle, but also in terms of technological capacity. Employment to output ratios combine the more-purely labour cost (and thus Heckscher-Ohlin) considerations of employment to value added ratios with Chandlerian technological considerations regarding the throughput rate of intermediate goods as suggestive of the prevailing technology in an industry (Chandler 1977). 
(Chandler 1977). In between are all machinery-producing industries, a set of closely-allied industries making products of rubber and plastic, glass and glass products, and other nonmetallic mineral products, as well as printing and publishing and paper and paper products. ${ }^{22}$ The correspondence between the labour-intensity data categorized by ISIC Rev. 2 and trade data from the World Trade Analyzer categorized by SITC (Standard International Trade Classification) Rev. 2 is shown in appendix table 1, and is based on a correspondence table produced by the United Nations (UN 2003).

In addition to our own classification scheme, we use a categorization of labourintensive and capital-intensive manufacturing industries constructed by UNIDO (1981) and employed by Van Beers (1998). We put manufacturing industries that are classified as neither labour-intensive nor capital-intensive by UNIDO into an in-between category such that three categories sum to the manufacturing total. The two most important data sources used to construct this classification scheme are for India (based on capital per employee) and the US (based on value added per employee) using data for the year 1965.

We use two additional classifications of less skilled labour-intensive manufacturing that are narrower than the labour-intensive manufacturing industry group we have constructed. First is that employed by Busse (2000), which is comprised of textile yarn and fabrics (SITC 65), glass, glassware and pottery (664-666), furniture and bedding (82), travel goods and handbags (83), apparel (84), footwear (85) and baby carriages, games, toys and sporting goods (894). All the component industries of this group are contained within our labour-intensive industry group with the exception of glass and glass products (ISIC 362 or SITC 664, 665), which we include in the in-between industry group.

Second is that constructed by Krause (1987) at the two-digit SITC level. Krause's classification is comprised of textile yarn and fabrics (SITC 65), non-metallic mineral manufactures (66), furniture and bedding (82), travel goods and handbags (83), apparel (84) and footwear (85). Similarly, all its component industries are contained within our labour-intensive industry group except for non-metallic mineral manufactures (SITC 66), which in our classification is split between labour-intensive and in-between industries. Krause also differs from our labour-intensive industry group and that employed by Busse in that it does not include baby carriages, games, toys and sporting goods (SITC 894). ${ }^{23}$ (The correspondence between our industry classification and those by Krause and Busse is illustrated in appendix table 1.)

Results of benchmark models for total trade, total manufacturing trade, and our three industry groups by labour intensity are shown in tables 4.B and 4.C, respectively without and with regional dummy variables. Focusing in table 4.B on total trade and total manufacturing trade, we see that all but one of the coefficient estimates are of the expected sign and are statistically significant for at least one of the two trade categories (the

\footnotetext{
${ }^{22}$ Note that some of the industries we have classified as in-between might also be classified as "continuous process," such as paper - combined with paper products in ISIC 341 - and glass combined with glass products in ISIC 362 (Chandler 1977, p. 353). However regression results are broadly similar between our in-between and capital-intensive industries, and thus reclassification between these industry groups should not have a substantive effect on results.

${ }^{23}$ The only exception to this regarding our classification and Busse's is that we include SITC 8946 not under ISIC 390 but rather under ISIC 382 minus 3825, as per the UN (2003) correspondence table, and the latter industry we classify as in-between.
} 
exception is $\mathbf{1}$ island $_{\boldsymbol{x} m}$, for which the coefficient estimate is not significantly different from zero, a result also found in Rose (1999)). After accounting for missing values (including when trade data is available but equal to zero), bilateral trade among the 135 countries yields well over 13,000 observations. Adjusted $R^{2}$ s are greater than 0.70 , similar to Rose's model evaluating 1990 data (1999). However, most of the variation in bilateral trade is captured by the model's core variables of $\log \left(\right.$ distance $\left._{x m}\right), \log \left(G D P /\right.$ cap $\left._{x}\right), \log$ $\left(G D P / c_{a p_{m}}\right), \log \left(\boldsymbol{p o p}_{x}\right)$ and $\log \left(\boldsymbol{p o p}_{m}\right)$. For total trade, for instance, these core variables by themselves account for 72.5 percent of the variation in bilateral trade, whereas all independent variables account for 73.6 percent of this variation (holding the sample constant to account for missing values of non-core independent variables). Coefficient estimates on these core variables provide elasticities that hover around unity, and $t$ statistics on all are greater than forty-five. Last, note that for manufacturing trade with breakdowns by labour intensity, reversing the sign on coefficient estimates on $\log \left(\boldsymbol{a r e a}_{x}\right)$ provides estimates of the effects of relative endowments of labour to land on exports. These are consistent with the Hecksher-Ohlin principle as regards these factors of production, being largest for labour-intensive manufacturing trade and smallest for capitalintensive manufacturing trade.

Looking at table 4.C for total trade and total manufacturing trade in the benchmark model including regional dummies, note that statistical significance is lost for the coefficient estimates on $\boldsymbol{R} \boldsymbol{T} \boldsymbol{A}_{x m}$ and exchange rate (88-92) $)_{x m}$, though it does hold for some industry groups within manufacturing trade.

For total trade and total manufacturing trade, there are statistically significant positive coefficient estimates on the regional dummy variables for East Asia and South Asia as exporters. (We also graphically show coefficient estimates for regional dummy variables for each of the six developing regions in figure 1.) For Sub-Saharan Africa as an exporter, there is also a statistically significant positive coefficient estimate for total trade but not total manufacturing trade, reflecting the region's reliance on exports of raw materials. Coefficient estimates are particularly large for East Asia, suggesting that the region exports nearly four times more total manufacturing trade than the OECD region, after accounting for determinants of trade as per the model. ${ }^{24}$ Moreover, East Asia is estimated to have high relative exports for all three manufacturing industry groups, ranking highest to lowest by labour-intensive, in-between, and capital-intensive manufacturing industries. This accords with the view that East Asian export success has come to be diversified across a wide range of manufacturing industries. Note too that these coefficient estimates are a good deal larger than those for the regional dummy variable for East Asia as an importer and indeed that the estimate for East Asia as an importer is negative for labour-intensive trade. This pattern of diversification for East Asia as an exporter contrasts with South Asia as an exporter, for which there are high relative exports only for labour-intensive manufactures.

For the Middle East-North Africa as an exporter, there are statistically significant negative coefficient estimates on the regional dummy variable for all five categories of trade. Coefficient estimates on for Middle East-North Africa as an importer are also significantly negative for total trade, total manufacturing trade, and labour-intensive trade, reflecting the region's generally weak integration into international goods markets. We also see negative coefficient estimates on the regional dummy variable for Latin AmericaCaribbean as an exporter for four of five categories of trade, which are statistically significant for total manufacturing trade and in-between manufacturing trade. (Though there is a significantly significant positive coefficient estimate for capital-intensive

$24 \mathrm{e}^{1.344}=3.83$, where 1.344 is the coefficient estimate on the dummy variable for total manufacturing trade for East Asia as an exporter. 
manufacturing trade for Latin America-Caribbean as an exporter, there is an even larger positive coefficient estimate on the import side). We will see below that it is the comparatively weak trade performance of the Middle East-North Africa and Latin America-Caribbean regions combined with their generally weaker than average FACB rights (and that countries in the region make up nearly one-third of the full sample of countries) that play an important role in accounting for the overall results of our analysis.

The strong positive coefficient estimate on the regional dummy variable for East Asia suggests a potential problem in the interpretation of the causal determinants of trade. For in the absence of regional dummy variables, coefficient estimates on any measure introduced into the trade model tending to have similar values for countries in the East Asia region might suggest that this measure is a causal determinant of export performance (depending on the extent to which variation in the measure is captured by other variables in the model and how the measure varies for other countries). A very similar question of interpretation occurred in the empirical literature on the effects of income inequality on long-run economic growth. While earlier studies found evidence that greater income inequality had a negative impact on long-run economic growth, this result was not found to be robust with respect to the inclusion of regional dummy variables (Deininger and Squire 1998). This was also a story of Asia, which has relatively low income inequality and relatively high growth rates. As with this literature, we regard results for models including regional dummy variables as more definitive in that they control for unspecified cross-regional variation and are driven by cross-country variation. However, we present main results with and without regional dummy variables, which facilitates comparison with prior studies surveyed above that did not include regional dummy variables.

\section{Empirical findings}

\subsection{Main results}

The FACB and democracy indicators are introduced one by one into the benchmark models. Each indicator is introduced pairwise for the exporting and importing country (as with $\log (G D P /$ cap $), \log ($ pop $)$ and $\log ($ area $)$ in the benchmark models). Shown in table 5.A are coefficient estimates on the FACB and democracy indicators for the exporting country in the context of the benchmark models, with and without regional dummy variables and using four industry group classifications. Given space constraints, our presentation focuses hereafter on these coefficient estimates, which provide estimates of the effects of FACB rights and democracy on exports while bilaterally controlling for the extent of FACB rights and democracy in the importing country. Light shading indicates that stronger FACB rights and democracy are associated with significantly higher exports (10 percent level or higher), and dark shading indicates that stronger FACB rights and democracy are associated with significantly lower exports.

Based on our own industry classification and including regional dummy variables, coefficient estimates of statistical significance generally suggest that stronger FACB rights and democracy are associated with higher exports, with the unionization rate for capitalintensive trade the exception. For total manufacturing trade, for instance, taking the coefficient estimate at face value suggests that a one-unit increase in the civil liberties index (on a scale of 0 to 10 ) would result in 9.0 percent higher exports. For the six main qualitative indicators (from Freedom House, the OECD and of our own construction), coefficient estimates are largest for in-between trade. With regional dummy variables, we see that stronger FACB rights and democracy are most often associated with higher labourintensive exports, with results strongly statistically significant for the two Freedom House 
indices and of borderline (10 percent) statistical significance for the weighted version of our FACB index and the OECD 2000 index. Without regional dummy variables, stronger rights are most often estimated to be associated with lower labour-intensive exports, though results are statistically significant only for the unionization rate and the dummy variable for violations of FACB rights in EPZs and of borderline significance for our unweighted FACB index. The exceptions are the Freedom House indices, which remain significantly positive. This one of the more robust findings of this study - that coefficient estimates on the Freedom House indices are generally positive and statistically significant, suggesting that countries with stronger civil liberties and political rights have higher exports, after controlling for other determinants of exports. Strikingly, this result for the Freedom House indices holds very strongly for labour-intensive manufacturing exports, regardless of the definition of labour-intensive manufacturing industries, with and without regional dummy variables, and throughout the sensitivity analysis.

Based on the UNIDO industry classification with regional dummy variables, for labour-intensive trade, we see that stronger FACB rights and democracy are estimated to be associated with higher exports, with or without regional dummy variables. Of the four classifications of labour-intensive manufactures, it is the UNIDO classification that provides the strongest association between stronger FACB rights and higher labourintensive manufacturing exports.

For Krause's classification of labour-intensive goods with regional dummy variables, we find statistically significant coefficient estimates suggesting that stronger civil liberties and political rights are associated with higher exports, though we find the opposite result for the unionization rate and the dummy variable for FACB violations in EPZs. For our two FACB indices and the two OECD indices, we find coefficient estimates not significantly different from zero, consistent with the view that changes in FACB rights have no effect on labour-intensive exports one way or another. Without regional dummy variables, we find statistically significant negative coefficient estimates on our two FACB indices and the OECD 1996 index. We see again that whether or not one includes regional dummy variables can have a substantive impact on estimates of the relationship between FACB rights and exports of labour-intensive manufactures.

It is with the classification used by Busse that we find the strongest negative relationship between FACB rights and exports of labour-intensive manufactures, and here too results vary considerably with and without the inclusion of regional dummy variables. Without regional dummy variables, we find statistically significant coefficient estimates suggesting that stronger FACB rights are associated with lower labour-intensive exports for all measures, except for the Freedom House indices, for which the opposite holds. Including regional dummy variables in the model, coefficient estimates on our weighted FACB index and the OECD 2000 index are no longer significantly different from zero.

We find then that depending on the classification of labour-intensive industries and the inclusion of regional dummy variables, it is possible to get statistically significant results of opposite sign on the unionization rate, our two FACB indices and the two OECD indices - that is, for five of the eight indicators we evaluate (five of the six specifically addressing FACB rights). There is a sense then in which none of the coefficient estimates on these five indicators are robust, at least with respect to labour-intensive trade. This seems a useful result in itself, and provides insight into why different studies on these issues might come to different findings using the same indicators of FACB rights and democracy. 
That said, we argue that we have reasonable grounds for taking as most definitive those results based on our own classification of industries by labour intensity and with the inclusion of regional dummy variables in the trade model. Similarly with the income inequality-growth literature, we argue that regional dummy variables belong in the trade model so that key results are driven by cross-country variation rather than unspecified cross-regional variation that may be proxied by any measure a region tends to have in common, such as indicators of FACB rights. The inclusion of regional dummy variables (as well as other variables in the model) also addresses to some extent evaluator bias in the construction of the Freedom House indices, for which a study has shown that evaluators tend to give more favorable scores to countries that are more like their own (Bollen and Paxton 2000).

Regarding industry classifications, we prefer our classification to that by UNIDO in that it is based on more countries and more up to date data. Regarding Krause's and Busse's industry classifications, one concern is that both classify the glass and glass products industry as labour-intensive, which we argue is not generally correct for the products from these industries that figure most importantly in international trade. ${ }^{25}$

More generally, it is important that any ranking of industries by labour or skill intensity use qualitative criteria to determine appropriate thresholds and thus industry groups. This is particularly so from the viewpoint of poorer developing countries, for which it seems preferable to include a as wide a range of labour-intensive industries as possible, providing the industries do not impose prohibitive technical barriers to production for international markets. This criterion holds true for each of the industries we have classified as labour-intensive, or at least for a great many of the goods produced within them. The groups we classify as capital-intensive and in-between also have a qualitative coherence as regards the type of process technology, with all capital-intensive industries characterized by "continuous process" technologies and in-between industries largely made up of the production of machines and non-metallic mineral products. It also seems generally preferable to include more rather than fewer industries within any given industry group so that results are less driven by the peculiarities of trade for a particular industry, such as resulting from tariffs, quotas or other industry-specific considerations. We see, for instance, that there are important differences between results based on Krause's and Busse's classifications, in spite of quite minor differences in industry classification. The issue is not just that we classify more industries as labour-intensive at the three-digit ISIC level, but that within several of these ISIC industries we include a wider range of SITC industries than are included in Krause's and Busse's classifications (appendix table 1). It is on these grounds that we prefer modelling results based on our own industry classification and including regional dummy variables, and we proceed with sensitivity analysis accordingly. As regards differences in industry classification, this of course does not affect results for total trade or total manufacturing trade.

\subsection{Sensitivity analysis}

The eight panels in table 5.B present findings from different tests of the sensitivity of results, for comparison with the upper left panel of table 5.A. We first drop the measure of exchange rate volatility from the model, as this variable is missing for several countries.

${ }^{25}$ In our twenty-nine industry ISIC classification, for instance, glass and glass products ranked twelfth by employment to output ratios and seventeenth by employment to value-added ratios. 
For total trade and total manufacturing trade, for instance, this yields over 500 additional observations. For labour-intensive trade, this leads to a significant positive coefficient estimate for our unweighted FACB index, and for capital-intensive trade to a loss of statistical significance for the unionization rate.

In addition to missing values in the raw trade data, there are a number of values that are zero and that thus drop out of the sample when we convert to natural logarithms, thus left-censoring the sample. We first address this with Tobit estimation, for which the main changes are for a loss of statistical significance (10 percent) for our weighted FACB index and the OECD 2000 index for labour-intensive goods. ${ }^{26}$ Following Rose (1999), we next address the issue of zero values by setting the log of small trade values (less than 50,000 US\$) to zero. For total trade and total manufacturing trade, this yields over 800 additional observations. Again we see the loss of statistical significance (10 percent) for the OECD 2000 index for labour-intensive goods and in addition the loss of statistical significance for the unionization rate for capital-intensive exports. ${ }^{27}$

Weighted least squares estimation is generally used as a correction for heteroskedasticity, which we address with White corrections. Following Rose, we use weighted least squares to give greater weight to the observations of larger countries, using both the natural logarithm of $\left(\boldsymbol{G D P} \boldsymbol{P}_{x} \boldsymbol{G D P} \boldsymbol{P}_{\boldsymbol{m}}\right)$ and $\left(\boldsymbol{p o p}_{\boldsymbol{x}} \boldsymbol{p o p}_{\boldsymbol{m}}\right)$ as weights. Using the former, the only substantive differences are the loss of borderline statistical significance (10 percent) for our weighted FACB index for labour-intensive manufactures and the loss of statistical significance on the unionization rate for capital-intensive manufactures. For the latter weight, we see in addition the loss of borderline statistical significance for our weighted FACB index and for the OECD 2000 index for labour-intensive manufactures.

Following Wood and Mayer (1998), for manufacturing trade categories we add to the trade model the natural logarithm of the average years of education attainment per adult (those aged fifteen or older) divided by land (in square kilometers) per adult, providing a measure of a country's skills-to-land ratio. ${ }^{28}$ This ratio addresses the hypothesis that the production of manufactured goods is skills-intensive compared to the production of primary goods and thus that a country's comparative advantage in manufactured goods is determined by its relative endowment of skills. Introducing the skills-to-land ratio into the model, for total manufacturing trade there is a loss of statistical significance for the coefficient estimates on the unionization rate and the OECD indices. For labour-intensive manufactures, the coefficient estimate on the unionization rate is now significantly negative, the coefficient estimates on the Freedom House indices are considerably smaller,

${ }^{26}$ We use as a left censoring value $\log (1 / 7)$, as we are taking averages over a seven-year period and as the trade data are in thousands.

${ }^{27}$ We also set to zero the log of small trade values less than 25,000 US\$, 5,000 US\$ and 1,000 US\$, for which the only substantive difference is results is the attainment of statistical significance, for all three of these lower thresholds, for the positive coefficient estimate on the dummy variable for FACB violations in EPZs for labour-intensive trade.

${ }^{28}$ The skills-to-land ratio is added for both the exporting and importing country. In the benchmark model for the exporting country, the coefficient estimate on the skills-to-land ratio is positive and statistically significant for total manufacturing trade and labour-intensive and capital-intensive manufacturing trade and positive but statistically insignificant for in-between manufacturing trade. Coefficient estimates on the FACB and democracy indicators are similar if we also include into the model, in addition to the skills-to-land ratio, the average years of education attainment per adult. The main difference is for labour-intensive manufacturing trade, specifically that the coefficient estimate on the unionization rate is no longer statistically significant. 
and there are negative but not statistically significant coefficient estimates on our two FACB indices and the two OECD FACB indices. For capital-intensive manufactures, there is a loss of statistical significance for the coefficient estimates on the Freedom House indices. For total manufacturing and labour-intensive trade, however, these differences do not result by and large from controlling for the skills-to-land ratio as such but from the fact that the education attainment data, and thus the skills-to-land ratio, are only available for a not altogether representative sample of 116 of our 135 countries. This is revealed by the generally similar results for total manufacturing and labour-intensive trade shown in the following panel, which does not introduce the skills-to-land ratio into the model but restricts the sample to countries for which the ratio is available. That is, the difference in results for total manufacturing and labour-intensive trade upon introducing the skills-toland ratio into the model is due in large measure to the truncated sample.

FACB rights and democracy may be themselves determined by a range of economic and social factors, and here we are particularly concerned with the endogeneity of FACB rights and democracy with respect to de facto trade openness. For instance, Maskus describes a scenario in which greater trade openness is associated with economic development that gives rise to demands for stronger protection of workers, citing as examples the cases of Japan, South Korea, Taiwan (China) and Singapore (Maskus 2003). Following Brown's (2000) suggestion (but focusing more narrowly on endogeneity with respect to trade openness), we regress the six main qualitative indicators of FACB rights and democracy on a constant, the ratio of total trade (exports plus imports) to GDP and this ratio squared and use the residuals from these regressions in the trade model. This then provides estimates of the effects of increases in FACB rights and democracy that are exogenous with respect to trade openness, shown in the lower right panel of table 5.B. Compared with our main results, coefficient estimates are in every instance less strongly positive and, for total trade and labour-intensive trade, sometimes negative, though never significantly so. Our weighted and unweighted FACB indices are no longer statistically significant for total trade and capital-intensive trade and indeed there is a general weakening of statistical significance for capital-intensive trade. For total manufacturing trade and in-between manufacturing trade, coefficient estimates all remain positive and statistically significant. For total manufacturing trade, for instance, coefficient estimates suggest that a one-unit strengthening of rights (on a scale of 0 to 10) would be associated with between a 1.7 percent (for our unweighted FACB index) to 7.8 percent (for the civil liberties index) increase in exports.

We take the coefficient estimates on these "residual" versions of indicators as the most definitive of our results and use them to derive estimates of changes in total manufacturing exports associated with changes in FACB rights and democracy using example pairs of countries within regions as reference points. More specifically, we estimate what would be the percent change and absolute change in total manufacturing exports if an example country within a region strengthened its current level of FACB rights and democracy to the level of another example country in a region, shown in table 5.C. Within Latin America-Caribbean, we take as examples Guatemala and Uruguay; within non-OECD East Asia, Indonesia and Thailand; within South Asia, Pakistan and India; within Sub-Saharan Africa, Zimbabwe and South Africa; and within Middle East-North Africa, Syria and Jordan. For these pairs, the country listed first generally has lower FACB rights and democracy scores. The two exceptions are that Indonesia and Thailand have the same score for the OECD 2000 index and that Pakistan has a slightly higher score than India for the Freedom House political rights index (based on the years 1993 to 1997).

For Guatemala and Uruguay, for example, if civil liberties in the former as measured by the Freedom House index were to strengthen to the level of the latter, our results 
suggest that this would result in an estimated 35.6 percent increase in total manufacturing exports, equivalent to 494 million (current) US dollars for Guatemala, relative to actual 1999 exports. The OECD indices provides estimates somewhat smaller in magnitude and our FACB indices estimates that are smaller yet but still equivalent to 133 and 192 million US dollars for the unweighted and weighted indices, respectively. Taking Syria and Jordan as examples, if democracy and FACB rights in the former were to strengthen to the level of the latter, the estimated percent increases in total manufacturing exports are of similar orders of magnitude as for the cases of Guatemala and Uruguay. This translates to between a 44 to 180 million US dollar increase in total manufacturing exports for Syria, based on the OECD 1996 index and the Freedom House civil liberties index, respectively, relative to actual 1999 exports. These lower US dollar amounts for Syria than Guatemala reflect of course that Syria's total manufacturing exports were a good deal lower than Guatemala's. These estimates are meant to be suggestive and one should not take them too literally. The regression coefficient estimates, for instance, apply to the average country, and there is no such thing as an average country. Nonetheless, they provide a sense that there may be nonnegligible economic benefits associated with the strengthening of democracy and FACB rights.

Taking the results of tables 5.A and 5.B together, a summary of our main robust results is represented in table 5.D, with breakdowns for total trade, total manufacturing trade and labour-intensive manufacturing trade and for democracy and FACB rights. In sum, we find robust relationships between stronger democracy and higher total exports, total manufacturing exports and labour-intensive manufacturing exports as well as between stronger FACB rights and higher total manufacturing exports and no robust relationships, positive or negative, between $\mathrm{FACB}$ rights and total exports and labour-intensive manufacturing exports. ${ }^{29}$

\subsection{Regional variation}

We next evaluate results with respect to regional variation. Shown in table 5.E are regional breakdowns for total manufacturing exports and labour-intensive manufacturing exports (based on the authors' industry classification) by percentage shares for the 1980 to 1999 period, with China broken out from other non-OECD East Asian countries, as well as change over the period by average annual growth rates and differences based on three-year endpoint averages. Starting with total manufacturing exports, for the OECD countries, the measure held fairly steady at around 80 percent until 1991, after which it declined to 72 percent in 1999. The three developing regions experiencing overall declines over the two decades were the transition countries, Sub-Saharan Africa and the Middle East-North Africa. For the transition countries though the measure increased steadily after bottoming out in 1991. Sub-Saharan Africa and the Middle East-North Africa also had, along with South Asia, the lowest shares of manufacturing exports in recent years. In South Asia, the measure did increase somewhat overall these years, though it remained below 1 percent. Note though that South Asia and Sub-Saharan Africa are not estimated to be underperformers in terms of exports once one accounts for determinants of trade as per the model, as suggested by the coefficient estimates on regional dummy variables. Their low shares of total manufacturing exports result rather from their weak potential to export. In particular, these two regions have very low levels of GDP per capita, far lower than any other region (table 3.C). In the Latin America-Caribbean region, the share of total manufacturing exports increased overall to a high of 4.8 percent in 1999 , but similar to the

${ }^{29}$ We leave aside mixed FACB results for total manufacturing trade upon introducing into the model the skills-to-land ratio, for reasons of sample bias noted above. 
transition countries, there was an overall decline until 1991, after which the measure steadily increased.

The clear winner in terms of shifting manufacturing export shares was the East Asia region. Average annual growth rates increased most rapidly for China, by 9.2 percent, but in terms of differences based on three-year endpoint averages, the largest increase was for the other non-OECD East Asian countries, with a 7.0 percentage point increase compared to a 2.9 percentage point increase for China. By 1999, China and other non-OECD East Asia accounted for 4.0 and 12.7 percent, respectively, of world manufacturing exports and 14.5 and 45.1 percent, respectively, of non-OECD manufacturing exports. Looking at labour-intensive manufacturing exports, the OECD countries still had 54.8 percent of the world's share of such exports as of 1999, though considerably down from 72.4 percent in 1980. The three regions have substantively higher shares of labour-intensive than total manufacturing exports are non-OECD East Asia, China and, to a lesser extent, South Asia. (See appendix table 2 for in-between and capital-intensive manufacturing exports, which show for the OECD countries sizeable share declines for in-between manufacturing exports from 89.8 to 76.5 percent but for capital-intensive manufacturing exports only from 74.4 to 72.9 percent.)

Even after accounting for determinants of trade as per the model, we find that East Asia and China have exceptional export performance, as indicated by coefficient estimates on regional dummy variables. This is confirmed when we create separate dummy variables for China (as an exporter and importer) and compare coefficient estimates on these with those for other non-OECD East Asian countries, shown in table 5.F for the benchmark model. We see that China's export performance was exceptional even compared to other East Asian countries. Coefficient estimates on the dummy variable for China as an exporter are strongly positive and higher than for the rest of East Asia for all five categories of trade, indicating that China's export success is diversified across the full range of manufacturing industries (though highest for labour-intensive manufactures and lowest for capital-intensive manufactures). In addition, coefficient estimates on China as an importer are negative for all five categories of trade, but only for labour-intensive trade for the rest of non-OECD East Asia. The coefficient estimate on China as an exporter suggests that China exports about seven times more total manufacturing trade than the OECD region, after accounting for determinants of trade as per the model. ${ }^{30}$ Coefficient estimates on regional dummy variables for East Asia and China become larger yet upon inclusion of the indicators of FACB rights and democracy, consistent with the FACB rights-exports relationship for East Asia and China being exceptional compared to the global sample. Thus the trade model, with or without FACB and democracy indicators, leaves much to be explained with regard to East Asia's and particularly China's export success. ${ }^{31}$

It is the exceptional export performance of East Asia combined with its weaker than average $\mathrm{FACB}$ rights that give rise to concerns that the former may result from the latter.

${ }^{30} \mathrm{e}^{1.963}=7.12$, where 1.963 is the coefficient estimate on the dummy variable for total manufacturing trade for China as an exporter.

${ }^{31}$ One interesting thing to note about China is that a sizeable share of its exports went to Hong Kong (China), which is one of the 135 countries or regions in our model, consistent with the structure of the World Trade Analyzer database. An average of 24.4 percent of China's total exports and 25.1 percent of its manufacturing exports went to Hong Kong (China) during the 1993 to 1999 period. 
We explore this and other aspects of regional variation by seeing how coefficient estimates on FACB and democracy indicators vary when we drop a region at a time from the sample, with results shown in table 5.G.

Excluding OECD countries from the sample, and thus focusing on developing countries, we find a similar overall pattern as for the full sample, showing that stronger FACB rights and democracy are associated with higher exports. The main differences are that the coefficient estimate on the unionization rate for labour-intensive exports is now significantly positive, that the coefficient estimate for the weighted FACB index for labour-intensive exports is more significantly positive, and that coefficient estimates on the unionization rate and the Freedom House indices for capital-intensive exports are no longer statistically significant. (We describe main rather than all differences upon dropping regions from the sample). Results do not vary greatly from the full sample upon the exclusion of South Asia, the transition countries or Sub-Saharan Africa. Dropping South Asia from the sample, we see a gain of statistical significance for the OECD indices for total trade and labour-intensive trade but a loss of statistical significance for capitalintensive trade. Dropping the transition countries from the sample, we see a loss of statistical significance for the Freedom House civil liberties index for capital-intensive trade as well as a loss of borderline (10 percent) statistical significance for the OECD 2000 index for labour-intensive trade. Dropping Sub-Saharan Africa from the sample, we see a loss of statistical significance for the Freedom House political rights index for capitalintensive trade and a gain of borderline statistical significance for the OECD 2000 index for total trade.

Upon dropping either the Latin America-Caribbean or the Middle East-North Africa region from the sample, we see more substantive differences from results for the full sample of countries, particularly for the OECD indices. For total trade and labour-intensive trade, we find statistically significant negative coefficient estimates on the OECD indices. For total manufacturing trade and capital-intensive trade, significantly positive coefficient estimates on the OECD indices for the full sample of countries are no longer significantly different from zero. A similar change on the OECD indices holds for in-between industries upon dropping the Middle East-North Africa region from the sample. We also see that the coefficient estimates on the indicator for FACB violations in EPZs becomes significantly positive upon exclusion of either the Latin America-Caribbean or the Middle East-North Africa regions from the sample. Last, we see that coefficient estimates on the Freedom House indices and our two FACB indices are no longer statistically significant at the 5 percent level or higher for capital-intensive exports. In general, then, we see a less clear picture of stronger FACB rights and democracy being associated with higher exports upon dropping either of these two regions from the sample.

We have seen that both the Latin America-Caribbean and Middle East-North Africa regions are under-performers in terms of international trade, as indicated by coefficient estimates on dummy variables for these regions (table 4.C, figure 1). We also see that the Latin America-Caribbean region has, on average, somewhat weaker rights by our two FACB indices and by the OECD indices than for the full sample of countries, though stronger than average by the Freedom House indices (table 3.C). And the Middle EastNorth Africa region has considerably weaker rights by all six of these indicators, with the gap particularly wide for the OECD indices. In our sample, there are twenty-six countries in the Latin America-Caribbean region and eighteen in the Middle East-North Africa region, or 32.6 percent of our total sample of 135 countries. This compares with sixteen countries in the East Asia-Pacific region, making up 11.9 percent of countries in the sample, and seven countries in South Asia (which performs well in labour-intensive exports), making up 5.2 percent of our sample. For a large share of our sample, then, we see that poor trade performance is associated with weaker than average FACB rights and democracy, a pattern that is particularly strong for the Middle East-North Africa. It is clear 
then that there is no necessary or general relationship between strong trade performance and weak FACB rights and democracy, as we see for the East Asia-Pacific region. Indeed in the context of the full sample of countries, the East Asia-Pacific region is more the exception than the rule in this regard.

We next drop the East Asia region (including China) from the sample. All coefficient estimates on the six main qualitative indicators of FACB rights and democracy are now more strongly positive. We see now, for instance, that coefficient estimates on the OECD indices for total trade are significantly positive. (In contrast, however, we also see for labour-intensive trade a statistically significant positive coefficient estimate on the dummy variable for violations of FACB rights in EPZs.) Dropping just China from the sample, we similarly see that coefficient estimates on the six main qualitative indicators of FACB rights and democracy are most often somewhat more strongly positive, consistent with China's exceptionally strong export performance and weak FACB rights and democracy. ${ }^{32}$

\section{Conclusions}

This study builds on prior cross-country econometric studies of the effects of FACB rights and democracy on international trade and is characterized by having roughly twice as many countries in the sample, using four definitions of labour-intensive manufacturing industries, evaluating results with and without regional dummy variables, using a wide range of indicators of FACB rights and democracy, addressing the endogeneity of FACB rights and democracy with respect to trade openness, and deriving results from a bilateral trade gravity model. Starting with aggregate trade flows, we find a robust result that stronger FACB rights are associated with higher total manufacturing exports and that stronger democracy is associated with higher total exports and total manufacturing exports. These results are consistent with the view that stronger FACB rights and democracy enhance export competitiveness, not hinder it. These results might seem surprising in light of the highly visible export successes of a number of countries having comparatively weak FACB rights and democracies, with certain East Asian countries springing to mind. The value of cross-country analysis, though, is that it tells us whether the experience of these countries is representative in this regard (after accounting for the determinants of exports as per the trade model). Our results on total trade and total manufacturing trade suggest, rather, that the East Asian experience is anomalous in the broader global context. For one must also be mindful of the less visible export failures of a great many countries having weak FACB rights and democracies and indeed that such countries are among the most weakly integrated into global markets. ${ }^{33}$ This suggests too the importance of evaluating as representative a sample of countries as possible.

${ }^{32}$ For the period in question, for instance, China gets scores of 0 for the two Freedom House indices, our own weighted and unweighted indices, and the two OECD indices.

${ }^{33}$ It is worth noting in this regard that eight countries are not included in our sample because GDP data are not available for them (though trade data are available for them in the World Trade Analyzer database). These are Afghanistan, Cuba, Iraq, Liberia, Libya, Myanmar, North Korea and Somalia. For the 1993 to 1997 period, all eight countries receive the lowest possible score by our FACB indices and the only country that does not receive the lowest possible score by the Freedom House indices is Liberia, which has very low scores of 1.67 for civil liberties and 0.42 for political rights. Given that all these countries are weakly integrated into the world economy, it is possible 
While such cross-country analysis is useful in determining representative patterns, it is of less help in understanding causal determinants of these patterns, and the result of a positive correlation between stronger FACB rights and democracy and stronger export performance begs for explanation. This is particularly so in light of the findings of prior studies that stronger FACB rights and democracy, using the same measures as the present study, are associated with higher labour costs even after accounting for labour productivity and other wage determinants (Rodrik 1999; Belser 2001; Kucera 2001). For surely one ought to expect that higher labour costs would have a negative impact on exports, all else being equal, particularly for exports of labour-intensive goods. Consistent with this expectation, we do not find such a consistent positive correlation for labour-intensive goods with respect to FACB rights, though we do with respect to democracy. We find in fact a very robust relationship between stronger democracy (measured by the Freedom House civil liberties and political rights indices) and higher labour-intensive exports. This relationship holds for all four definitions of labour-intensive manufacturing industries, with and without regional dummy variables, and throughout the sensitivity analysis. This is consistent with the view that democracy is beneficial for the export performance of labourintensive manufactures.

We find, however, statistically significant results of opposite sign for five of our six indicators specifically addressing FACB rights depending solely on which of the four definitions of labour-intensive manufacturing industries is used and whether we include regional dummy variables in the model. Using our preferred definition of labour-intensive manufacturing industries and including regional dummy variables, we find that there is essentially no relationship between FACB rights and labour-intensive exports. The less positive relationship for labour-intensive manufacturing exports than total manufacturing exports is consistent with the theoretical expectation that labour-intensive industries are particularly sensitive to higher labour costs resulting from stronger FACB rights. In light of the Heckscher-Ohlin principle, this suggests that stronger FACB rights are of particular concern for developing countries'export competitiveness. However, this concern holds only in a relative sense - relative to total manufacturing exports - since we do not find solid evidence that stronger FACB rights have an adverse impact on the exports of labourintensive manufactures but rather that there is essentially no relationship. It is worth recalling too that the exceptional export performance of the non-OECD East-Asian countries holds across the range of manufacturing industries, for labour-intensive and capital-intensive industries and those in-between. Insofar then as other developing countries seek to emulate this pattern of diversified success, what matters then is the relationship between total manufacturing exports and FACB rights.

Taking the results for total manufacturing trade and labour-intensive manufacturing trade together suggests that possible negative effects through labour costs of stronger FACB rights and democracy are offset by other positive effects of stronger FACB rights and democracy. Based on the work of Rodrik (1997) and others, we have suggested in the introduction to this paper that these positive effects may be related to the greater economic and social stability enjoyed by countries with stronger FACB rights and democracy, with such stability in turn facilitating export competitiveness. But clearly this is only a tentative hypothesis requiring further investigation. 


\section{References}

Belser, Patrick. 2001. Four Essays on Trade and Labour Standards, unpublished Ph.D. dissertation, University of Sussex.

Bergstrand, Jeffrey. 1989. "The Generalized Gravity Equation, Monopolistic Competition, and the Factor-Proportions Theory in International Trade," in The Review of Economics and Statistics 71(1): 143-153.

Bollen, Kenneth and Pamela Paxton. 2000. "Subjective Measures of Liberal Democracy," in Comparative Political Studies 33(1): 58-86.

Brown, Drusilla. 2000. "International Trade and Core Labour Standards: A Survey of the Recent Literature," OECD Labour Market and Social Policy - Occasional Papers No. 43.

Brown, Drusilla, Alan Deardorff and Robert Stern. 1996. "International Labor Standards and Trade: A Theoretical Analysis," in Jagdish Bhagwati and Robert Hudec (eds.) Fair Trade and Harmonization: Prerequisites for Free Trade? Cambridge, Massachusetts: MIT Press.

Busse, Matthias. 2001. "Do Labour Standards Affect Comparative Advantage? Evidence for Labour-intensive Goods," Centre for International Economic Studies Discussion Paper No. 0142 .

Chandler, Alfred. 1977. The Visible Hand: The Managerial Revolution in American Business. Cambridge, Massachusetts: Harvard University Press.

Cutler, Harvey, David Berri and Terutomo Ozawa. 2003. "Market Recycling in LaborIntensive Goods, Flying-geese Style: An Empirical Analysis of East Asian Exports to the U.S.," in Journal of Asian Economics 14(1): 35-50.

Deardorff, Alan. 1995. "Determinants of Bilateral Trade: Does Gravity Work in a Neoclassical World?,” NBER Working Paper No. 5377.

Deininger, Klaus and Lyn Squire. 1998. "New Ways of Looking at Old Issues: Inequality and Growth," in Journal of Development Economics 57(2): 259-287.

EIU. 1996. World Trade Report (fourth quarter). London: The Economist Intelligence Unit.

Evenett, Simon and Wolfgang Keller. 1998. "On Theories Explaining the Success of the Gravity Equation,” NBER Working Paper No. 6529.

Flanagan, Robert. 2003. "Labor Standards and International Competitive Advantage," in Robert Flanagan (ed.) International Labor Standards: Globalization, Trade and Public Policy. Stanford, California: Stanford University Press.

Freedom House. 1999. Freedom in the World: The Annual Survey of Political Rights and Civil Liberties 1998-1999. New York: Freedom House. 
Freeman, Richard. 1994. "American Exceptionalism in the Labor Market: Union-Nonunion Differentials in the United States and Other Countries," in Clark Kerr and Paul Staudohar (eds.) Labor Economics and Industrial Relations: Markets and Institutions. Cambridge, Massachusetts: Harvard University Press.

Ghose, Ajit. 2003. Jobs and Incomes in a Globalizing World. Geneva: International Labour Office.

Hanson, Gordon. 2001. "Should Countries Promote Foreign Direct Investment?," G-24 Discussion Paper Series, No. 9 (UNCTAD and Center for International Development).

Hatem, Fabrice. 1997. International Investment: Towards the Year 2001. New York: United Nations.

Kucera, David. 2001. "The Effects of Core Worker Rights on Labour Costs and Foreign Direct Investment: Evaluating the "Conventional Wisdom," 'International Institute for Labour Studies Working Paper No. 130.

Krause, Lawrence. 1987. "The Structure of Trade in Manufactured Goods in the East and Southeast Asian Region," in Colin Bradford Jr. and William Branson (eds.) Trade and Structural Change in Pacific Asia. Chicago: University of Chicago Press.

Leamer, Edward E. and James Levinsohn. 1995. "International Trade Theory: The Evidence," in Gene M. Grossman and Kenneth Rogoff (eds.) The Handbook of International Economics, vol. III. Amsterdam, Elsevier Science.

Mah, Jai S. 1997. "Core Labour Standards and Export Performance in Developing Countries," in The World Economy 20(6): 773-785.

Maskus, Keith. 2003. "Trade and Competiveness Aspects of Environmental and Labor Standards in East Asia," in Kathie Krumm and Homi Kharas (eds.) East Asia Integrates: A Trade Policy Agenda for Shared Growth. Washington, DC: The World Bank.

OECD. 1996. Trade, Employment and Labour Standards: A Study of Core Workers' Rights and International Trade. Paris: OECD. OECD. 2000. International Trade and Core Labour Standards. Paris: OECD.

OECD. 2001. OECD Science, Technology and Industry Scoreboard: Towards a Knowledgebased economy. Paris: OECD.

Portes, Alejandro. 1994. "By-passing the Rules: The Dialectics of Labour Standards and Informalization in Less Developed Countries", in Werner Sengenberger and Duncan Campbell (eds.) International Labour Standards and Economic Interdependence. Geneva, International Institute for Labour Studies.

Rodrik, Dani. 1996. "Labor Standards in International Trade: Do They Matter and What Do We Do About Them?," in Robert Lawrence, Dani Rodrik, and John Whalley (eds.) Emerging Agenda for Global Trade: High Stakes for Developing Countries. Washington, D.C.: Overseas Development Council.

Rodrik, Dani. 1997. “Democracy and Economic Performance,” Harvard University. 
Rodrik, Dani. 1999. “Democracies Pay Higher Wages," in The Quarterly Journal of Economics 114(3): 707-738.

Rose, Andrew. 1999. "One Money, One Market: Estimating the Effects of Common Currencies on Trade," National Bureau of Economic Research Working Paper No. 7432.

Sengenberger, Werner. 2002. Globalization and Social Progress: The Role and Impact of International Labour Standards. Bonn: Friedrich-Ebert-Stiftung.

Tyres, Rodney, Prue Phillips and Christopher Findlay. 1987. "ASEAN and China Exports of Labor-intensive Manufactures: Performance and Prospects," in ASEAN Economic Bulletin 3(3): 339-367.

UN. 2003. 2000 Industrial Commodity Statistics Yearbook: Production Statistics (1991-2000). New York: United Nations.

UNIDO. 1981. World Industry in 1980. New York: United Nations.

Van Beers, Cees. 1998. "Labour Standards and Trade Flows of OECD Countries," in The World Economy 21(1): 57-73.

Wood, Adrian and Jörg Mayer. 1998. “Africa's Export Structure in Comparative Perspective," in UNCTAD Economic Development and Regional Dynamics in Africa: Lessons from the East Asian Experience. Geneva: United Nations Conference on Trade and Development. 


\section{Table 3.A: Indicator of freedom of association and collective bargaining rights (hypothetical example for a single country)}

Thirty-seven evaluation criteria

Freedom of association/collective bargaining-related civil liberties

1 Murder or disappearance of union members or organizers

2 Other violence against union members or organizers

3 Arrest, detention, imprisonment, or forced exile for union membership or activities

4 Interference with union rights of assembly, demonstration, free opinion, free expression

5 Seizure or destruction of union premises or property

Right to establish and join union and worker organizations

6 General prohibitions

7 General absence resulting from socio-economic breakdown

8 Previous authorization requirements

9 Employment conditional on non-membership in union

10 Dismissal or suspension for union membership or activities

11 Interference of employers (attempts to dominate unions)

12 Dissolution or suspension of union by administrative authority

13 Only workers' committees \& labour councils permitted

14 Only state-sponsored or other single unions permitted

15 Exclusion of tradeable/industrial sectors from union membership

16 Exclusion of other sectors or workers from union membership

17 Other specific de facto problems or acts of prohibition

18 Right to establish and join federations or confederations of unions

19 Previous authorization requirements regarding above row

Other union activities

20 Right to elect representatives in full freedom

21 Right to establish constitutions and rules

22 General prohibition of union/federation participation in political activities

23 Union control of finances

Right to collectively bargain

24 General prohibitions

25 Prior approval by authorities of collective agreements

26 Compulsory binding arbitration

27 Intervention of authorities

28 Scope of collective bargaining restricted by non-state employers

29 Exclusion of tradeable/industrial sectors from right to collectively bargain

30 Exclusion of other sectors or workers from right to collectively bargain

31 Other specific de facto problems or acts of prohibition

Right to strike

32 General prohibitions

33 Previous authorization required by authorities

34 Exclusion of tradeable/industrial sectors from right to strike

35 Exclusion of other sectors or workers from right to strike

36 Other specific de facto problems or acts of prohibition

Export processing zones

37 Restricted rights in EPZs
Sources

D

Dummy eights Dummy*Weights $(0=$ no evidence, $(1,1.25,1.5$,

\begin{tabular}{|c|c|c|c|}
\hline & $1=$ evidence) & 1.75 or 2$)$ & \\
\hline & 0 & 2 & 0 \\
\hline$a b$ & 1 & 2 & 2 \\
\hline $\mathrm{a}$ & 1 & 2 & 2 \\
\hline $\mathrm{ab}$ & 1 & 2 & 2 \\
\hline & 0 & 2 & 0 \\
\hline
\end{tabular}

\begin{tabular}{|c|c|c|c|}
\hline & 0 & default & $n a$ \\
\hline & 0 & default & $n a$ \\
\hline & 0 & 1.5 & 0 \\
\hline & 0 & 1.5 & 0 \\
\hline $\mathrm{abc}$ & 1 & 1.5 & 1.5 \\
\hline $\mathrm{a}$ & 1 & 1.5 & 1.5 \\
\hline & 0 & 2 & 0 \\
\hline & 0 & 2 & 0 \\
\hline & 0 & 1.5 & 0 \\
\hline & 0 & 2 & 0 \\
\hline $\mathrm{ab}$ & 1 & 2 & 2 \\
\hline $\mathrm{a}$ & 1 & 1.5 & 1.5 \\
\hline & 0 & 1.5 & 0 \\
\hline & 0 & 1 & 0 \\
\hline & & &
\end{tabular}

\begin{tabular}{|c|c|c|c|}
\hline $\mathrm{ab}$ & 1 & 1.5 & 1.5 \\
\hline & 0 & 1.5 & 0 \\
\hline $\mathrm{b}$ & 1 & 1.5 & 1.5 \\
\hline $\mathrm{c}$ & 1 & 1.5 & 1.5 \\
\hline
\end{tabular}

\begin{tabular}{|c|c|c|c|}
\hline & 0 & default & $n a$ \\
\hline & 0 & 1.5 & 0 \\
\hline & 0 & 1.5 & 0 \\
\hline & 0 & 1.5 & 0 \\
\hline & 0 & 1.5 & 0 \\
\hline & 0 & 1.75 & 0 \\
\hline & 0 & 1.75 & 0 \\
\hline $\mathrm{ab}$ & 1 & 1.5 & 1.5 \\
\hline
\end{tabular}

\begin{tabular}{|c|c|c|c|}
\hline & 0 & 2 & 0 \\
\hline & 0 & 1.5 & 0 \\
\hline & 0 & 1.5 & 0 \\
\hline & 0 & 1.5 & 0 \\
\hline $\mathrm{ac}$ & 1 & 1.5 & 1.5 \\
\hline
\end{tabular}

\begin{tabular}{|l|l|l|l|}
\hline $\mathrm{a}$ & 1 & 2 & 2 \\
\hline \multicolumn{3}{c|}{ Non-scaled (raw) weighted score: } & $\mathbf{2 2}$ \\
\hline
\end{tabular}

Sources:

a: International Confederation of Free Trade Unions (ICFTU), Annual Survey of Violations of Trade Union Rights .

b: U.S. State Department, Country Reports on Human Rights Practices.

c: ILO, Report of the Committee on Freedom of Association.

Note: $n a$ indicates not applicable; default indicates a maximum scaled country score of 10 (or 0 in the rescaled version used in the trade model). 
Table 3.B: Correlation coefficients (Pearson) between GDP per capita and indicators of democracy and FACB rights: mid-1990s

$1 \mathrm{GDP} / \mathrm{cap}(\mathrm{USS})$

2 GDP/cap (PPP)

3 Unionization rate

4 FH civil liberties index

5 FH political rights index

6 FACB index unweighted

7 FACB index weighted

8 OECD FACB index 1996

9 OECD FACB index 2000

$10 F A C B$ in $E P Z s$

\begin{tabular}{|c|c|c|c|c|c|c|c|c|c|}
\hline & & & & $F H$ & & & & OECD & \\
\hline $\begin{array}{c}\text { GDP/cap } \\
\text { (US\$) }\end{array}$ & $\begin{array}{c}G D P / c a p \\
(P P P)\end{array}$ & $\begin{array}{c}\text { Unionization } \\
\text { rate }\end{array}$ & $\begin{array}{c}\text { FH civil } \\
\text { liberties } \\
\text { index }\end{array}$ & $\begin{array}{c}\text { political } \\
\text { rights } \\
\text { index }\end{array}$ & $\begin{array}{c}\text { FACB index } \\
\text { unweighted }\end{array}$ & $\begin{array}{c}\text { FACB } \\
\text { index } \\
\text { weighted }\end{array}$ & $\begin{array}{c}O E C D \\
F A C B \\
\text { index } 1996\end{array}$ & $\begin{array}{c}F A C B \\
\text { index } \\
2000\end{array}$ & $\begin{array}{c}F A C B \text { in } \\
\text { EPZS }\end{array}$ \\
\hline
\end{tabular}

$0.960 \quad 1.000$

$0.367 \quad 0.413$

$0.564 \quad 0.644$

$0.481 \quad 0.576$

$0.371 \quad 0.367$

$0.392 \quad 0.394$

$0.612 \quad 0.660$

$0.612 \quad 0.666$

0.666

$$
\begin{array}{r}
1.000 \\
0.398 \\
0.360 \\
0.374 \\
0.375 \\
0.387 \\
0.367 \\
-0.191
\end{array}
$$

1.000

0.934

0.583

0.616

0.858

0.862

$-0.127$

1.000

0.551

0.585

0.836

0.822

$-0.074$

1.000

0.989

0.733

1.000

$\begin{array}{lll}-0.263 & -0.255 & -0.191\end{array}$

0.696

0.749

0.715

1.000

$-0.336$

$-0.340$

$-0.404$

1.000

$-0.409$

1.000

Sources: See Appendix: Data Sources.

Note: The critical two-tailed values for 98 degrees of freedom (100 observations) are $0.164,0.195$ and 0.254 at the 10,5 and 1 percent levels, respectively. 
Table 3.C: Descriptive statistics for GDP per capita and indicators of democracy and FACB rights: mid-1990s

\begin{tabular}{|c|c|c|c|c|c|c|c|c|c|c|c|c|c|}
\hline \multirow{3}{*}{ Number of countries } & $\begin{array}{c}\text { Number of } \\
\text { observations }\end{array}$ & OECD & $\begin{array}{c}\text { Latin } \\
\text { America- } \\
\text { Caribbean }\end{array}$ & $\begin{array}{c}\text { Non-OECD } \\
\text { East Asia- } \\
\text { Pacific }\end{array}$ & $\begin{array}{c}\text { South } \\
\text { Asia }\end{array}$ & $\begin{array}{l}\text { Transition } \\
\text { countries }\end{array}$ & $\begin{array}{c}\text { Sub- } \\
\text { Saharan } \\
\text { Africa }\end{array}$ & $\begin{array}{l}\text { Middle } \\
\text { East- } \\
\text { North } \\
\text { Africa }\end{array}$ & & & All regions & & \\
\hline & & 23 & 26 & 16 & 7 & 8 & 37 & 18 & & & 135 & & \\
\hline & & Mean & Mean & Mean & Mean & Mean & Mean & Mean & Mean & Std. dev. & Coeff. of var. & Maximum & Minimum \\
\hline 1 GDP/cap (US\$) & 135 & 22,502 & 3,073 & 5,457 & 521 & 2,443 & 637 & 6,745 & 6,318 & 9,191 & 1.45 & 38,633 & 107 \\
\hline 2 GDP/cap (PPP) & 131 & 20,267 & 5,584 & 6,144 & 1,988 & 6,772 & 1,635 & 8,916 & 7,428 & 7,636 & 1.03 & 28,116 & 473 \\
\hline 3 Unionization rate & 86 & 32.79 & 15.27 & 16.99 & 14.63 & 48.16 & 13.71 & 28.69 & 23.30 & 17.95 & 0.77 & 77.20 & 2.00 \\
\hline 4 FH civil liberties index & 134 & 9.08 & 6.70 & 4.03 & 3.33 & 6.41 & 3.70 & 3.24 & 5.32 & 3.00 & 0.56 & 10.00 & 0.00 \\
\hline 5 FH political rights index & 134 & 9.71 & 7.37 & 4.42 & 4.82 & 7.28 & 3.58 & 3.17 & 5.69 & 3.55 & 0.62 & 10.00 & 0.00 \\
\hline $6 F A C B$ index unweighted & 133 & 7.99 & 4.73 & 3.68 & 3.06 & 5.48 & 5.39 & 4.26 & 5.25 & 3.12 & 0.59 & 10.00 & 0.00 \\
\hline $7 F A C B$ index weighted & 133 & 8.24 & 5.01 & 4.05 & 3.19 & 5.81 & 5.52 & 4.51 & 5.48 & 3.01 & 0.55 & 10.00 & 0.00 \\
\hline 8 OECD FACB index 1996 & 74 & 9.71 & 6.30 & 3.67 & 4.17 & 10.00 & 4.56 & 3.33 & 6.53 & 3.47 & 0.53 & 10.00 & 0.00 \\
\hline 9 OECD FACB index 2000 & 74 & 9.86 & 6.30 & 4.33 & 4.17 & 10.00 & 4.56 & 3.33 & 6.66 & 3.36 & 0.50 & 10.00 & 0.00 \\
\hline $10 F A C B$ in $E P Z s$ & 133 & 0.04 & 0.42 & 0.20 & 0.57 & 0.00 & 0.17 & 0.06 & 0.20 & 0.40 & 2.04 & 1.00 & 0.00 \\
\hline
\end{tabular}

Sources: See Appendix: Data Sources. 


\section{Table 4.A: Manufacturing industry classification by labour intensity}

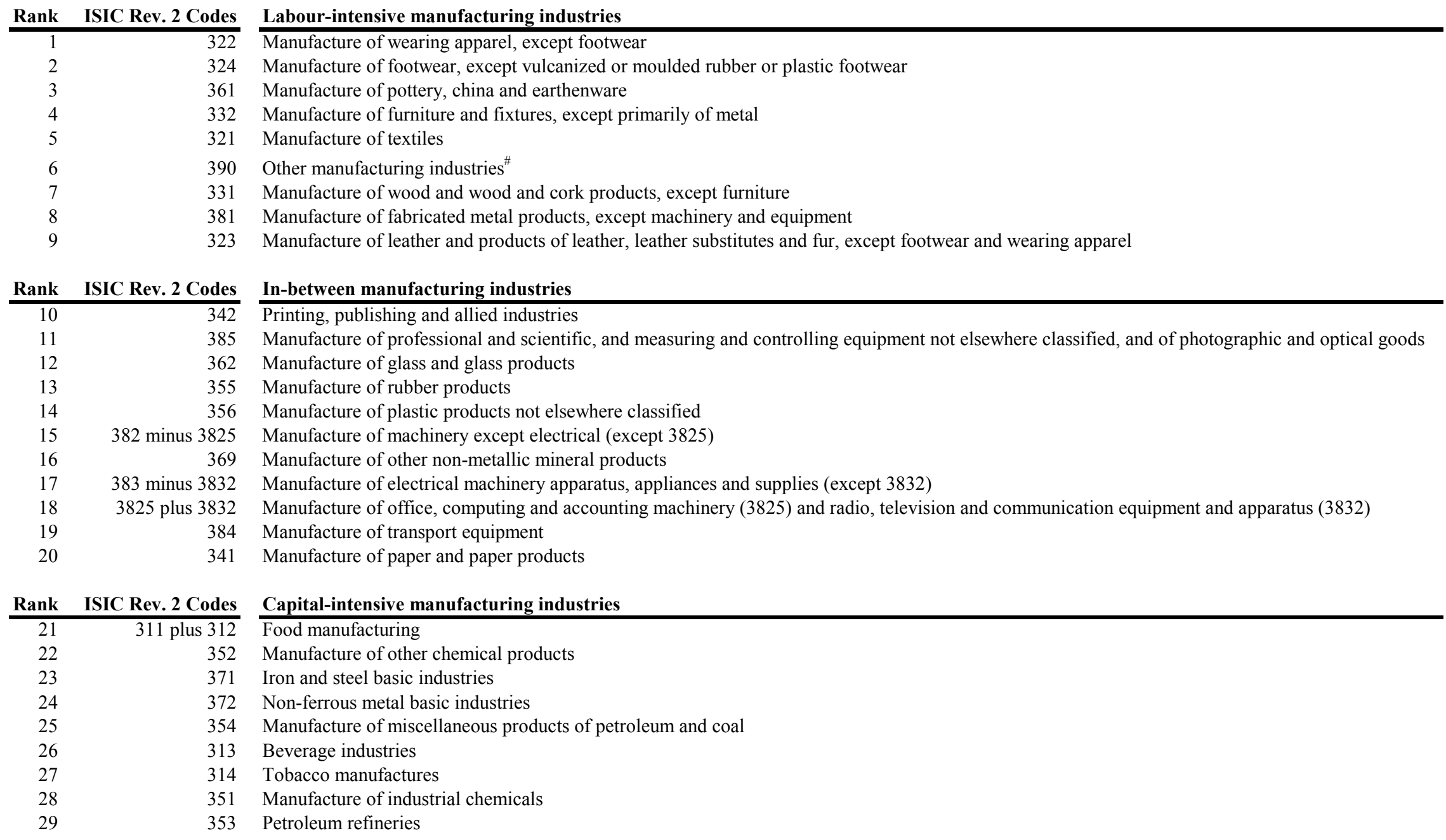

Source: Full industry names are from the United Nations Statistics Division, at: http://unstats.un.org/unsd/cr/registry/

Note: ${ }^{\#}$ Comprised of manufacture of jewellery and related articles, musical instruments, sporting and athletic goods, and manufacturing industries not elsewhere classified. 
Table 4.B: Benchmark trade model results without regional dummy variables

\begin{tabular}{|c|c|c|c|c|c|}
\hline & Total trade & $\begin{array}{c}\text { Total mfg. } \\
\text { trade }\end{array}$ & $\begin{array}{c}\text { Labour- } \\
\text { intensive mfg. } \\
\text { trade }\end{array}$ & $\begin{array}{l}\text { In-between } \\
\text { mfg. trade }\end{array}$ & $\begin{array}{c}\text { Capital- } \\
\text { intensive mfg. } \\
\text { trade }\end{array}$ \\
\hline$c$ & $-34.153 * * *$ & $-33.463 * * *$ & $-31.727 * * *$ & $-33.192 * * *$ & $-28.255 * * *$ \\
\hline & -96.487 & -92.334 & -78.142 & -83.070 & -70.214 \\
\hline \multirow{2}{*}{$\log \left(\right.$ distance $\left._{x m}\right)$} & $-1.275 * * *$ & $-1.319 * * *$ & $-1.219 * * *$ & $-1.285 * * *$ & $-1.363 * * *$ \\
\hline & -47.510 & -48.353 & -41.590 & -43.400 & -46.362 \\
\hline \multirow[t]{2}{*}{$\log \left(G D P /\right.$ cap $\left._{x}\right)$} & $1.264 * * *$ & $1.428 * * *$ & $1.089 * * *$ & $1.593 * * *$ & $1.278 * * *$ \\
\hline & 126.648 & 141.924 & 95.050 & 141.570 & 106.590 \\
\hline \multirow[t]{2}{*}{$\log \left(G D P / c a p_{m}\right)$} & $1.015 * * *$ & $0.903 * * *$ & $0.961 * * *$ & $0.760 * * *$ & $0.773 * * *$ \\
\hline & 97.186 & 84.084 & 79.243 & 64.122 & 63.261 \\
\hline \multirow{2}{*}{$\log \left(\operatorname{pop}_{x}\right)$} & $1.257 * * *$ & $1.349 * * *$ & $1.485 * * *$ & $1.408 * * *$ & $1.027 * * *$ \\
\hline & 83.714 & 89.715 & 85.655 & 84.311 & 58.981 \\
\hline \multirow{2}{*}{$\log \left(p o p_{m}\right)$} & $1.068 * * *$ & $0.935 * * *$ & $0.767 * * *$ & $0.735 * * *$ & $0.921 * * *$ \\
\hline & 71.437 & 62.156 & 45.957 & 43.708 & 53.526 \\
\hline \multirow[t]{2}{*}{$\log \left(\operatorname{area}_{x}\right)$} & $-0.122 * * *$ & $-0.197 * * *$ & $-0.366 * * *$ & $-0.250 * * *$ & $-\mathbf{0 . 0 2 7} * *$ \\
\hline & -10.121 & -16.644 & -26.308 & -19.385 & -2.027 \\
\hline \multirow[t]{2}{*}{$\log \left(\operatorname{area}_{m}\right)$} & $-0.137 * * *$ & $-0.111 * * *$ & $-0.073 * * *$ & $-0.045 * * *$ & $-0.124 * * *$ \\
\hline & -11.627 & -9.178 & -5.559 & -3.374 & -8.890 \\
\hline \multirow[t]{2}{*}{ common border $_{x m}$} & $1.230 * * *$ & $1.285 * * *$ & $1.291 * * *$ & $1.471 * * *$ & $1.131 * * *$ \\
\hline & 9.988 & 10.170 & 9.966 & 11.508 & 8.731 \\
\hline \multirow[t]{2}{*}{1 landlocked $_{x m}$} & $-0.431 * * *$ & $-0.521 * * *$ & $-0.317 * * *$ & $-0.253 * * *$ & $-0.796 * * *$ \\
\hline & -10.144 & -12.124 & -6.532 & -5.380 & -15.739 \\
\hline \multirow[t]{2}{*}{2 landlocked $_{x m}$} & -0.208 & $-0.457 * * *$ & $-0.441 * * *$ & -0.117 & $-0.989 * * *$ \\
\hline & -1.550 & -3.349 & -2.776 & -0.768 & -5.771 \\
\hline \multirow[t]{2}{*}{1 island $_{x m}$} & -0.012 & 0.001 & $-0.208 * * *$ & 0.038 & 0.075 \\
\hline & -0.275 & 0.020 & -4.080 & 0.757 & 1.446 \\
\hline \multirow[t]{2}{*}{2 island $_{x m}$} & $0.639 * * *$ & $0.768 * * *$ & $0.474 * * *$ & $0.545 * * *$ & $0.835 * * *$ \\
\hline & 4.739 & 5.868 & 3.068 & 3.722 & 5.257 \\
\hline \multirow[t]{2}{*}{$R T A_{x m}$} & $0.086 *$ & $0.128 * * *$ & $0.296 * * *$ & 0.054 & $0.244 * * *$ \\
\hline & 1.873 & 2.766 & 5.735 & 1.029 & 4.689 \\
\hline \multirow[t]{2}{*}{ hange rate $(88-92)_{x m}$} & $-0.462 * * *$ & $-0.263 *$ & $-1.098 * * *$ & $-0.654 * * *$ & 0.249 \\
\hline & -3.061 & -1.687 & -5.989 & -3.623 & 1.397 \\
\hline $\mathbf{N}$ & 13,743 & 13,199 & 10,995 & 11,269 & 11,400 \\
\hline $\operatorname{Adj} . R^{2}$ & 0.735 & 0.743 & 0.683 & 0.729 & 0.661 \\
\hline$F$-Stat. & 2729.581 & 2729.265 & 1696.200 & 2168.358 & 1587.745 \\
\hline
\end{tabular}

Notes: Bolded numbers indicate regression coefficient estimates, below which are associated $t$-statistics.

$*, * *$ and $* * *$ indicate two-tailed significance at 10, 5 and 1 percent levels, respectively. 
Table 4.C: Benchmark trade model results with regional dummy variables

\begin{tabular}{|c|c|c|c|c|c|}
\hline & Total trade & $\begin{array}{c}\text { Total mfg. } \\
\text { trade }\end{array}$ & $\begin{array}{c}\text { Labour- } \\
\text { intensive mfg. } \\
\text { trade }\end{array}$ & $\begin{array}{c}\text { In-between } \\
\text { mfg. trade }\end{array}$ & $\begin{array}{c}\text { Capital- } \\
\text { intensive mfg. } \\
\text { trade }\end{array}$ \\
\hline$c$ & $-32.096 * * *$ & $-31.125 * * *$ & $-29.128 * * *$ & $-32.150 * * *$ & $-28.076 * * *$ \\
\hline & -66.313 & -63.931 & -54.620 & -60.203 & -49.435 \\
\hline \multirow[t]{2}{*}{$\log \left(\right.$ distance $\left._{x m}\right)$} & $-1.458 * * *$ & $-1.552 * * *$ & $-1.516 * * *$ & $-1.549 * * *$ & $-1.560 * * *$ \\
\hline & -50.246 & -53.061 & -48.310 & -50.186 & -47.986 \\
\hline \multirow[t]{2}{*}{$\log \left(G D P /\right.$ cap $\left._{x}\right)$} & $1.377 * * *$ & $1.497 * * *$ & $1.237 * * *$ & $1.630 * * *$ & $1.340 * * *$ \\
\hline & 66.887 & 72.817 & 55.781 & 73.260 & 54.981 \\
\hline \multirow[t]{2}{*}{$\log \left(G D P /\right.$ cap $\left._{m}\right)$} & $0.982 * * *$ & $0.928 * * *$ & $0.977 * * *$ & $0.912 * * *$ & $0.820 * * *$ \\
\hline & 48.809 & 46.544 & 45.439 & 41.762 & 35.199 \\
\hline \multirow[t]{2}{*}{$\log \left(\operatorname{pop}_{x}\right)$} & $1.157 * * *$ & $1.178 * * *$ & $1.221 * * *$ & $1.238 * * *$ & $0.973 * * *$ \\
\hline & 66.912 & 69.072 & 65.345 & 66.196 & 46.373 \\
\hline \multirow[t]{2}{*}{$\log \left(\operatorname{pop}_{m}\right)$} & $1.059 * * *$ & $0.969 * * *$ & $0.817 * * *$ & $0.793 * * *$ & $0.967 * * *$ \\
\hline & 65.577 & 60.473 & 46.563 & 43.783 & 51.050 \\
\hline \multirow[t]{2}{*}{$\log \left(\operatorname{area}_{x}\right)$} & $\mathbf{- 0 . 0 5 9} * * *$ & $-0.094 * * *$ & $-0.182 * * *$ & $-0.162 * * *$ & 0.010 \\
\hline & -4.615 & -7.416 & -13.047 & -11.811 & 0.649 \\
\hline \multirow[t]{2}{*}{$\log \left(\right.$ area $\left._{m}\right)$} & $-0.146 * * *$ & $-0.128 * * *$ & $-0.103 * * *$ & $-0.040 * * *$ & $-0.126 * * *$ \\
\hline & -11.844 & -10.378 & -7.744 & -2.916 & -8.554 \\
\hline \multirow[t]{2}{*}{ common border $_{x m}$} & $0.913 * * *$ & $0.908 * * *$ & $0.857 * * *$ & $1.041 * * *$ & $0.781 * * *$ \\
\hline & 7.140 & 6.953 & 6.347 & 8.049 & 5.862 \\
\hline \multirow[t]{2}{*}{1 landlocked $_{x m}$} & $\mathbf{- 0 . 5 5 5 * * *}$ & $-0.641 * * *$ & $-0.441 * * *$ & $-0.385 * * *$ & $-0.831 * * *$ \\
\hline & -13.132 & -15.147 & -9.440 & -8.371 & -16.169 \\
\hline \multirow[t]{2}{*}{2 landlocked $_{x m}$} & $\mathbf{- 0 . 4 3 6} * * *$ & $-0.647 * * *$ & $-0.579 * * *$ & $-0.334 * *$ & $-1.040 * * *$ \\
\hline & -3.198 & -4.905 & -3.973 & -2.287 & -6.072 \\
\hline \multirow[t]{2}{*}{1 island $_{x m}$} & $-0.084 *$ & $-0.076 *$ & $-0.327 * * *$ & -0.008 & 0.084 \\
\hline & -1.904 & -1.706 & -6.721 & -0.163 & 1.612 \\
\hline \multirow[t]{2}{*}{2 island $_{x m}$} & $0.458 * * *$ & $0.585 * * *$ & 0.199 & $0.366 * * *$ & $0.817 * * *$ \\
\hline & 3.534 & 4.679 & 1.394 & 2.669 & 5.203 \\
\hline \multirow[t]{2}{*}{$\boldsymbol{R T} \boldsymbol{A}_{x m}$} & 0.022 & 0.025 & $0.133 * * *$ & -0.051 & $0.142 * * *$ \\
\hline & 0.504 & 0.568 & 2.773 & -1.050 & 2.800 \\
\hline \multirow[t]{2}{*}{ exchange rate $(88-92)_{x m}$} & -0.062 & $-\mathbf{0 . 0 5 3}$ & $-0.355 *$ & $-0.474 * *$ & 0.110 \\
\hline & -0.383 & -0.319 & -1.867 & -2.454 & 0.562 \\
\hline \multirow[t]{2}{*}{ Latin America-Caribbean $_{x}$} & $-\mathbf{0 . 0 5 4}$ & $-0.155 * *$ & $\mathbf{- 0 . 0 0 7}$ & $-0.747 * * *$ & $0.317 * * *$ \\
\hline & -0.841 & -2.359 & -0.102 & -10.050 & 4.160 \\
\hline \multirow[t]{2}{*}{ Latin America-Caribbean $_{m}$} & $-0.168 * *$ & $0.184 * * *$ & -0.081 & $0.893 * * *$ & $0.395 * * *$ \\
\hline & -2.374 & 2.643 & -1.118 & 11.538 & 4.857 \\
\hline \multirow[t]{2}{*}{ non-OECD East Asia-Pacific ${ }_{x}$} & $1.135 * * *$ & $1.344 * * *$ & $2.023 * * *$ & $1.172 * * *$ & $0.786 * * *$ \\
\hline & 15.174 & 17.937 & 24.819 & 14.655 & 9.156 \\
\hline non-OECD East Asia-Pacific ${ }_{m}$ & 0.102 & $0.182 * *$ & $-0.158 *$ & $0.731 * * *$ & $0.385 * * *$ \\
\hline & 1.298 & 2.302 & -1.908 & 8.193 & 4.147 \\
\hline South Asia $_{x}$ & $0.678 * * *$ & $0.952 * * *$ & $1.832 * * *$ & -0.012 & 0.114 \\
\hline & 6.140 & 8.558 & 15.284 & -0.098 & 0.804 \\
\hline South Asia $_{m}$ & $-0.468 * * *$ & $-\mathbf{0 . 3 8 7} * * *$ & $-0.542 * * *$ & $0.324 * *$ & -0.127 \\
\hline & -3.953 & -3.281 & -4.339 & 2.570 & -0.920 \\
\hline Transition countries $_{x}$ & $-\mathbf{0 . 0 1 0}$ & $0.232 * * *$ & $-0.392 * * *$ & $0.192 * *$ & $0.435 * * *$ \\
\hline & -0.129 & 2.831 & -4.121 & 2.135 & 4.520 \\
\hline Transition countries $_{m}$ & $-0.674 * * *$ & $-0.704 * * *$ & $-0.481 * * *$ & $-0.192 *$ & $-0.564 * * *$ \\
\hline & -7.199 & -7.487 & -4.859 & -1.833 & -5.014 \\
\hline Sub-Saharan Africa $x$ & $0.437 * * *$ & 0.003 & 0.133 & 0.009 & $0.235 * *$ \\
\hline & 4.765 & 0.035 & 1.360 & 0.093 & 2.105 \\
\hline Sub-Saharan Africa ${ }_{m}$ & $-0.177 *$ & $0.212 * *$ & 0.151 & $0.834 * * *$ & $0.344 * * *$ \\
\hline & -1.944 & 2.363 & 1.544 & 8.379 & 3.256 \\
\hline Middle East-North Africa ${ }_{x}$ & $\mathbf{- 0 . 6 5 8} * * *$ & $-0.781 * * *$ & $-0.763 * * *$ & $-1.257 * * *$ & $-0.573 * * *$ \\
\hline & -9.556 & -11.582 & -10.478 & -17.211 & -7.341 \\
\hline Middle East-North Africa ${ }_{m}$ & $-0.556 * * *$ & $-0.345 * * *$ & $-0.291 * * *$ & $0.319 * * *$ & 0.085 \\
\hline & -7.995 & -5.015 & -4.005 & 4.313 & 1.086 \\
\hline $\mathbf{N}$ & 13,743 & 13,199 & 10,995 & 11,269 & 11,400 \\
\hline Adj. $R^{2}$ & 0.751 & 0.765 & 0.728 & 0.761 & 0.673 \\
\hline$F$-Stat. & 1597.181 & 1655.468 & 1134.780 & 1380.811 & 905.337 \\
\hline
\end{tabular}

Notes: Bolded numbers indicate regression coefficient estimates, below which are associated $t$-statistics.

$*, * *$ and $* * *$ indicate two-tailed significance at 10,5 and 1 percent levels, respectively. 


\section{Table 5.A: Trade model results by industry classification and with and without regional dummy variables}

\begin{tabular}{|c|c|c|c|c|c|c|c|c|c|c|c|c|c|c|c|c|c|}
\hline \multirow{3}{*}{$\begin{array}{l}\text { Authors' industry } \\
\text { classification } \\
\text { Unionization rate }\end{array}$} & \multicolumn{8}{|c|}{ With regional dummy variables } & \multicolumn{9}{|c|}{ Without regional dummy variables } \\
\hline & \multicolumn{2}{|c|}{ Total trade } & $\begin{array}{l}\text { Total mfg. } \\
\text { trade }\end{array}$ & \multicolumn{2}{|c|}{$\begin{array}{l}\text { Labour- } \\
\text { intensive } \\
\text { mfg. trade }\end{array}$} & $\begin{array}{c}\text { In-between } \\
\text { mfg. trade }\end{array}$ & \multicolumn{2}{|c|}{$\begin{array}{l}\text { Capital- } \\
\text { intensive } \\
\text { mfg. trade }\end{array}$} & \multicolumn{2}{|c|}{ Total trade } & $\begin{array}{l}\text { Total mfg. } \\
\text { trade }\end{array}$ & \multicolumn{2}{|c|}{$\begin{array}{l}\text { Labour- } \\
\text { intensive } \\
\text { mfg. trade }\end{array}$} & \multicolumn{2}{|c|}{$\begin{array}{c}\text { In-between } \\
\text { mfg. trade }\end{array}$} & \multicolumn{2}{|c|}{$\begin{array}{l}\text { Capital- } \\
\text { intensive } \\
\text { mfg. trade }\end{array}$} \\
\hline & \begin{tabular}{|l|l|}
0.000 \\
\end{tabular} & & \begin{tabular}{|l|l|}
0.003 & $* * *$ \\
\end{tabular} & 0.000 & & \begin{tabular}{|l|l|}
0.010 & $* * *$ \\
\end{tabular} & $-0.003 *$ & $*$ & \begin{tabular}{l|l|}
-0.001 \\
\end{tabular} & & \begin{tabular}{|l|l|}
0.005 & $* * *$ \\
\end{tabular} & -0.005 & $* * *$ & 0.012 & $* * *$ & -0.001 & \\
\hline FH civil liberties index $x_{x}$ & 0.059 & $* * *$ & \begin{tabular}{|l|l|}
0.090 & $* * *$ \\
\end{tabular} & 0.115 & $* * *$ & \begin{tabular}{|l|l|l|}
0.128 & $* * *$ \\
\end{tabular} & $0.028 *$ & $* *$ & $0.061 *$ & $* * *$ & \begin{tabular}{l|l|}
0.082 & $* * * *$ \\
\end{tabular} & $\mathbf{0 . 0 7 7}$ & $* * *$ & 0.127 & $* * *$ & 0.059 & $* * *$ \\
\hline FH political rights index $x_{x}$ & $0.045 *$ & $* * *$ & \begin{tabular}{l|l|l|}
0.064 & $* * *$ \\
\end{tabular} & 0.069 & $* * *$ & \begin{tabular}{|l|l|l}
0.095 & $* * *$ \\
\end{tabular} & 0.023 ; & $* *$ & 0.046 * & $* * *$ & \begin{tabular}{l|l|}
0.066 & $* * * *$ \\
\end{tabular} & 0.059 & $* * *$ & 0.092 & $* * *$ & 0.046 & $* * *$ \\
\hline$F A C B$ index unweighted $x_{x}$ & 0.026 & $* * *$ & \begin{tabular}{l|l|l|}
0.041 & $* * *$ \\
\end{tabular} & \begin{tabular}{c|c|}
0.008 \\
\end{tabular} & & \begin{tabular}{|l|l|}
0.064 & $* * *$ \\
\end{tabular} & $0.030:-$ & $* * *$ & 0.029 * & $* * *$ & \begin{tabular}{|l|l|}
0.029 & $* * *$ \\
\end{tabular} & -0.013 & $\%$ & 0.077 & $* * *$ & 0.024 & $* * *$ \\
\hline$F_{A C B}$ index weighted $_{x}$ & 0.031 & $\% * *$ & \begin{tabular}{|l|l|}
0.047 & $* * *$ \\
\end{tabular} & 0.016 & $*$ & \begin{tabular}{l|l|l|}
0.081 & $* * *$ \\
\end{tabular} & 0.030 * & $* * *$ & 0.034 * & $* * *$ & \begin{tabular}{l|l|l|}
0.035 & $* * *$ \\
\end{tabular} & -0.007 & & 0.093 & $* * *$ & 0.027 & $* * *$ \\
\hline OECD FACB index $1996_{x}$ & 0.013 & & \begin{tabular}{|l|l|}
0.060 & $* * *$ \\
\end{tabular} & 0.009 & & \begin{tabular}{l|l|l|}
0.125 & $* * *$ \\
\end{tabular} & 0.049 * & $* * *$ & -0.008 & & \begin{tabular}{l|l|l|}
0.027 & $* *$ \\
\end{tabular} & -0.019 & & 0.044 & $* * *$ & 0.008 & \\
\hline OECD FACB index $2000_{x}$ & 0.017 & & \begin{tabular}{|l|l|}
0.072 & $* * *$ \\
\end{tabular} & 0.027 & $\%$ & \begin{tabular}{|l|l|}
0.139 & $* * *$ \\
\end{tabular} & 0.048 * & $* * *$ & \begin{tabular}{l|l|}
0.001 \\
\end{tabular} & & \begin{tabular}{l|l|}
0.044 & $* * *$ \\
\end{tabular} & 0.002 & & 0.072 & $* * *$ & 0.016 & \\
\hline$F A C B$ in $E P Z s_{x}$ & -0.211 & $* * *$ & \begin{tabular}{ll|l|}
-0.364 & $* * * *$ \\
\end{tabular} & 0.072 & & \begin{tabular}{|l|l|}
-0.312 & $* * *$ \\
\end{tabular} & -0.426 & $* * *$ & $-0.227 \mid *$ & $* * *$ & 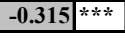 & 0.145 & $\% *$ & -0.496 & $* * *$ & -0.305 & $* * *$ \\
\hline $\begin{array}{l}\text { UNIDO industry } \\
\text { classification }\end{array}$ & & & & $\begin{array}{l}\text { Labou } \\
\text { intensi } \\
\text { mfg. tra }\end{array}$ & & $\begin{array}{l}\text { In-between } \\
\text { mfg. trade }\end{array}$ & $\begin{array}{r}\text { Capita } \\
\text { intensi } \\
\text { mfg. tra }\end{array}$ & $\begin{array}{l}\text { al- } \\
\text { ive } \\
\text { ade } \\
\end{array}$ & & & & $\begin{array}{l}\text { Labou } \\
\text { intensi } \\
\text { mfg. tr }\end{array}$ & $\begin{array}{l}\text { ur- } \\
\text { ive } \\
\text { cade } \\
\end{array}$ & $\begin{array}{l}\text { In-betw } \\
\text { mfg. tr: }\end{array}$ & $\begin{array}{l}\text { ween } \\
\text { rade }\end{array}$ & $\begin{array}{r}\text { Capit } \\
\text { intens } \\
\text { mfg. tr }\end{array}$ & $\begin{array}{l}\text { tal- } \\
\text { sive } \\
\text { rade }\end{array}$ \\
\hline Unionization rate $_{x}$ & & & & 0.006 & $* * *$ & \begin{tabular}{|l|l|}
0.001 & \\
\end{tabular} & 0.005 & $* * *$ & & & & 0.008 & $* * *$ & \begin{tabular}{|l|l|}
-0.001 \\
\end{tabular} & & 0.009 & $* * *$ \\
\hline FH civil liberties index $x_{x}$ & & & & 0.134 & $* * *$ & \begin{tabular}{l|l|l|}
0.091 & $* * *$ \\
\end{tabular} & 0.056 : & $* * *$ & & & & 0.111 & $* * *$ & 0.122 & $* * *$ & 0.087 & $* * *$ \\
\hline FH political rights index ${ }_{x}$ & & & & 0.106 & $* * *$ & \begin{tabular}{l|l|l|}
0.056 & $* * *$ \\
\end{tabular} & 0.039 : & $* * *$ & & & & 0.094 & $* * *$ & 0.087 & $* * *$ & 0.062 & $* * *$ \\
\hline$F A C B$ index unweighted $x_{x}$ & & & & 0.034 & $\div * *$ & \begin{tabular}{l|l|l|}
0.053 & $* * *$ \\
\end{tabular} & $0.020 *$ & $* *$ & & & & 0.035 & $* * *$ & 0.041 & $* * *$ & 0.037 & $* * *$ \\
\hline FACB index weighted $_{x}$ & & & & 0.047 & 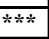 & \begin{tabular}{|l|l|}
0.054 & $* * *$ \\
\end{tabular} & 0.028 : & $* * *$ & & & & 0.046 & $* * *$ & 0.044 & $* * *$ & 0.046 & $* * *$ \\
\hline OECD FACB index $1996_{x}$ & & & & 0.051 & $* * *$ & 0.039 & 0.063 : & $\div * *$ & & & & 0.020 & & 0.011 & & 0.037 & $* * *$ \\
\hline OECD FACB index $2000_{x}$ & & & & 0.065 & $* * *$ & 0.020 & 0.089 * & $* * *$ & & & & 0.042 & $* * *$ & 0.011 & & 0.064 & $* * *$ \\
\hline$F A C B$ in $E P Z s_{x}$ & & & & 0.042 & & \begin{tabular}{|l|l|l|}
-0.519 & $* * *$ \\
\end{tabular} & $-0.300=$ & $* * *$ & & & & \begin{tabular}{|c|c|}
-0.028 \\
\end{tabular} & & -0.223 & $* *$ & -0.406 & $* * *$ \\
\hline $\begin{array}{l}\text { Krause's industry } \\
\text { classification }\end{array}$ & & & & $\begin{array}{l}\text { Labou } \\
\text { intensi } \\
\text { mfg. tra }\end{array}$ & $\begin{array}{l}\text { ur- } \\
\text { ive } \\
\text { ade } \\
\end{array}$ & & & & & & & $\begin{array}{l}\text { Labou } \\
\text { intens } \\
\text { mfg. tr }\end{array}$ & $\begin{array}{l}\text { ur- } \\
\text { sive } \\
\text { rade } \\
\end{array}$ & & & & \\
\hline Unionization rate $_{x}$ & & & & -0.005 & $* * *$ & & & & & & & -0.005 & $* * *$ & & & & \\
\hline FH civil liberties index $x$ & & & & 0.101 & $* * *$ & & & & & & & 0.048 & $* * *$ & & & & \\
\hline FH political rights index $x_{x}$ & & & & 0.079 & $* * *$ & & & & & & & 0.050 & $* * *$ & & & & \\
\hline$F A C B$ index unweighted $x$ & & & & -0.004 & & & & & & & & -0.032 & $* * *$ & & & & \\
\hline FACB index weighted $x_{x}$ & & & & 0.002 & & & & & & & & -0.028 & $* * *$ & & & & \\
\hline OECD FACB index $1996_{x}$ & & & & \begin{tabular}{l|l}
-0.007 \\
\end{tabular} & & & & & & & & -0.039 & $* * *$ & & & & \\
\hline OECD FACB index $2000_{x}$ & & & & \begin{tabular}{l|l}
0.023 \\
\end{tabular} & & & & & & & & -0.013 & & & & & \\
\hline$F A C B$ in $E P Z s_{x}$ & & & & 0.214 & $* * *$ & & & & & & & 0.197 & $* * *$ & & & & \\
\hline $\begin{array}{l}\text { Busse's industry } \\
\text { classification }\end{array}$ & & & & $\begin{array}{l}\text { Labou } \\
\text { intensi } \\
\text { mfg. tra }\end{array}$ & $\begin{array}{l}\text { ur- } \\
\text { ive } \\
\text { ade }\end{array}$ & & & & & & & $\begin{array}{l}\text { Labou } \\
\text { intens } \\
\text { mfg. tr }\end{array}$ & $\begin{array}{l}\text { ur- } \\
\text { sive } \\
\text { rade }\end{array}$ & & & & \\
\hline Unionization rate $_{x}$ & & & & -0.005 & $* * *$ & & & & & & & -0.005 & $* * *$ & & & & \\
\hline FH civil liberties index $x_{x}$ & & & & 0.102 & $* * *$ & & & & & & & 0.046 & $* * *$ & & & & \\
\hline FH political rights index $x_{x}$ & & & & 0.072 & $\div * *$ & & & & & & & 0.046 & $* * *$ & & & & \\
\hline FACB index unweighted $x_{x}$ & & & & -0.020 & $* *$ & & & & & & & -0.049 & $* * *$ & & & & \\
\hline FACB index weighted ${ }_{x}$ & & & & \begin{tabular}{l|l|}
-0.013 \\
\end{tabular} & & & & & & & & -0.045 & $* * *$ & & & & \\
\hline OECD FACB index $1996_{x}$ & & & & -0.043 & $* *$ & & & & & & & -0.057 & $* * *$ & & & & \\
\hline$O E C D F A C B$ index $2000_{x}$ & & & & -0.016 & & & & & & & & -0.030 & $* *$ & & & & \\
\hline$F A C B$ in $E P Z s_{x}$ & & & & 0.324 & $* * *$ & & & & & & & 0.295 & $* * *$ & & & & \\
\hline
\end{tabular}

Note: $*, * *$ and $* * *$ indicate two-tailed significance at 10,5 and 1 percent levels, respectively.

Light shading indicates that stronger FACB rights are associated with significantly higher exports (10 percent level or higher), while dark shading indicates that stronger FACB rights are associated with significantly lower exports. 


\section{Table 5.B: Trade model sensitivity analysis results}

\begin{tabular}{|c|c|c|c|c|c|c|c|c|c|c|}
\hline \multirow{2}{*}{$\begin{array}{l}\text { Authors' industry } \\
\text { classification, w/ regional } \\
\text { dummy variables }\end{array}$} & \multicolumn{2}{|c|}{ Total trade } & \multicolumn{2}{|c|}{$\begin{array}{c}\text { Total mfg. } \\
\text { trade }\end{array}$} & \multicolumn{2}{|c|}{$\begin{array}{l}\text { Labour- } \\
\text { intensive } \\
\text { mfg. trade }\end{array}$} & \multicolumn{2}{|c|}{$\begin{array}{l}\text { In-between } \\
\text { mfg. trade }\end{array}$} & \multicolumn{2}{|c|}{$\begin{array}{l}\text { Capital- } \\
\text { intensive } \\
\text { mfg. trade }\end{array}$} \\
\hline & \multicolumn{10}{|c|}{ Dropping exchange rate $(88-92)_{x m}$ from the model } \\
\hline$\overline{\text { Unionization rate }_{x}}$ & 0.001 & & 0.004 & $* * *$ & 0.000 & & 0.009 & $* * *$ & -0.002 & \\
\hline FH civil liberties index $x_{x}$ & 0.068 & $* * *$ & 0.097 & $* * *$ & 0.117 & $\% * *$ & 0.130 & $* * *$ & 0.046 & $\div * *$ \\
\hline FH political rights index $x_{x}$ & 0.053 & $* * *$ & 0.071 & $* * *$ & 0.075 & $* * *$ & 0.100 & $* * *$ & 0.036 & $* * *$ \\
\hline FACB index unweighted ${ }_{x}$ & 0.033 & $* * *$ & 0.048 & $* * *$ & 0.015 & * & 0.070 & $* * *$ & 0.040 & $\div * *$ \\
\hline FACB index weighted $x$ & 0.038 & $* * *$ & 0.054 & $* * *$ & 0.023 & $* * *$ & 0.086 & $* * *$ & 0.042 & $* * *$ \\
\hline OECD FACB index $1996_{x}$ & 0.013 & & 0.061 & $* * *$ & 0.008 & & 0.124 & $* * *$ & 0.054 & $* * *$ \\
\hline$O E C D$ FACB index $2000_{x}$ & 0.018 & & 0.074 & $* * *$ & 0.027 & $\%$ & 0.139 & $* * *$ & 0.053 & $\div * *$ \\
\hline$F A C B$ in $E P Z s_{x}$ & -0.201 & $* * *$ & -0.361 & $* * *$ & 0.085 & & $\mid-0.302$ & $* * *$ & -0.441 & $\div * *$ \\
\hline
\end{tabular}

Labour-

Capital-

Total mfg. intensive In-between intensive Total trade trade mfg.trade mfg. trade mfg.trade

Weighted least squares using $\log \left(P O P_{x} * P O P_{m}\right)$ as weight

\begin{tabular}{|c|c|c|c|c|c|c|c|c|c|}
\hline 0.001 & & 0.004 & $\div \div$ & 0.000 & & 0.010 & $* * *$ & \begin{tabular}{|c|}
-0.002 \\
\end{tabular} & \\
\hline 0.054 & & & $\%$ & & & 128 & $* * *$ & & \\
\hline \begin{tabular}{|c|}
0.040 \\
\end{tabular} & $\% * *$ & & $\div \div$ & 4 & $\% * *$ & 093 & $* * *$ & & $\approx *$ \\
\hline 0.022 & * & & $\div * *$ & 0. & & 65 & $* * *$ & & $\div *$ \\
\hline 0.026 & & & $\% * \%$ & & & 082 & **** & & $* * *$ \\
\hline 0.002 & & 0 & $\div * *$ & -0.004 & & 19 & $* * *$ & & $* * *$ \\
\hline 0.006 & & & $\div * *$ & & & 133 & $* * *$ & 0.052 & 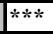 \\
\hline 0.199 & 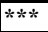 & 353 & * & 087 & & .293 & $* * *$ & 0.414 & (1) \\
\hline
\end{tabular}

Authors' industry

classification, $w /$ regional

dummy variables

Unionization rate $_{x}$

FH civil liberties index

FH political rights index $x_{x}$

$F A C B$ index unweighted $x_{x}$

$F A C B$ index weighted

OECD FACB index $1996_{x}$

OECD FACB index 2000

$F A C B$ in $E P Z s_{x}$

Tobit estimation

\begin{tabular}{|r|c|c|c|c|c|c|c|c|c|}
\hline $\mathbf{0 . 0 0 0}$ & & $\mathbf{0 . 0 0 3}$ & $* * *$ & $\mathbf{0 . 0 0 0}$ & & $\mathbf{0 . 0 1 0}$ & $* * *$ & $-\mathbf{0 . 0 0 3}$ & $* *$ \\
\hline $\mathbf{0 . 0 5 9}$ & $* * *$ & $\mathbf{0 . 0 9 0}$ & $* * *$ & $\mathbf{0 . 1 1 5}$ & $* * *$ & $\mathbf{0 . 1 2 8}$ & $* * *$ & $\mathbf{0 . 0 2 8}$ & $* *$ \\
\hline $\mathbf{0 . 0 4 6}$ & $* * *$ & $\mathbf{0 . 0 6 6}$ & $* * *$ & $\mathbf{0 . 0 7 1}$ & $* * *$ & $\mathbf{0 . 1 0 1}$ & $* * *$ & $\mathbf{0 . 0 2 5}$ & $* *$ \\
\hline $\mathbf{0 . 0 2 7}$ & $* * *$ & $\mathbf{0 . 0 4 1}$ & $* * *$ & $\mathbf{0 . 0 0 7}$ & & $\mathbf{0 . 0 6 6}$ & $* * *$ & $\mathbf{0 . 0 3 2}$ & $* * *$ \\
\hline $\mathbf{0 . 0 3 1}$ & $* * *$ & $\mathbf{0 . 0 4 8}$ & $* * *$ & $\mathbf{0 . 0 1 4}$ & & $\mathbf{0 . 0 8 3}$ & $* * *$ & $\mathbf{0 . 0 3 2}$ & $* * *$ \\
\hline $\mathbf{0 . 0 1 3}$ & & $\mathbf{0 . 0 5 9}$ & $* * *$ & $\mathbf{0 . 0 0 6}$ & & $\mathbf{0 . 1 2 1}$ & $* * *$ & $\mathbf{0 . 0 4 8}$ & $* * *$ \\
\hline $\mathbf{0 . 0 1 7}$ & & $\mathbf{0 . 0 7 1}$ & $* * *$ & $\mathbf{0 . 0 2 4}$ & & $\mathbf{0 . 1 3 5}$ & $* * *$ & $\mathbf{0 . 0 4 7}$ & $* * *$ \\
\hline $\mathbf{- 0 . 2 0 7}$ & $* * *$ & $\mathbf{- 0 . 3 5 6}$ & $* * *$ & $\mathbf{0 . 0 9 3}$ & & $\mathbf{- 0 . 2 8 1}$ & $* * *$ & $\mathbf{- 0 . 4 1 6}$ & $* * *$ \\
\hline
\end{tabular}

Authors' industry

classification, $w /$ regional

dummy variables

Unionization rate ${ }_{x}$

FH civil liberties index

FH political rights index $x_{x}$

FACB index unweighted ${ }_{x}$

FACB index weighted

OECD FACB index 1996,

$O E C D$ FACB index 2000

$F A C B$ in $E P Z s_{x}$

Setting log of small trade values (less than 50k US\$) to zero

\begin{tabular}{|r|r|r|r|r|r|r|r|r|r|}
\hline 0.000 & & 0.004 & $* *$ & 0.001 & & 0.011 & $* * *$ & -0.003 & \\
\hline 0.088 & $* * *$ & 0.120 & $* * *$ & 0.135 & $* * *$ & 0.148 & $* * *$ & 0.053 & $* * *$ \\
\hline 0.065 & $* * *$ & 0.087 & $* * *$ & 0.082 & $* * *$ & 0.115 & $* * *$ & 0.043 & $* * *$ \\
\hline 0.034 & $* * *$ & 0.049 & $* * *$ & 0.013 & & 0.069 & $* * *$ & 0.045 & $* * *$ \\
\hline 0.039 & $* * *$ & 0.056 & $* * *$ & 0.023 & $* *$ & 0.085 & $* * *$ & 0.045 & $* * *$ \\
\hline 0.003 & & 0.057 & $* * *$ & $-\mathbf{0 . 0 0 6}$ & & 0.136 & $* * *$ & 0.044 & $* *$ \\
\hline 0.010 & & 0.074 & $* * *$ & 0.016 & & 0.156 & $* * *$ & 0.049 & $* *$ \\
\hline-0.145 & $* *$ & $-\mathbf{0 . 3 7 2}$ & $* * *$ & $\mathbf{0 . 0 8 5}$ & & $-\mathbf{0 . 3 2 4}$ & $* * *$ & $-\mathbf{0 . 4 5 1}$ & $* * *$ \\
\hline
\end{tabular}

Authors' industry

classification, $\mathbf{w} /$ regional

dummy variables

Unionization rate ${ }_{x}$

FH civil liberties index

FH political rights index $x_{x}$

FACB index unweighted

FACB index weighted

OECD FACB index 1996

$O E C D$ FACB index 2000

$F A C B$ in $E P Z s_{x}$
Weighted least squares using $\log \left(G D P_{x} * G D P_{m}\right)$ as weight

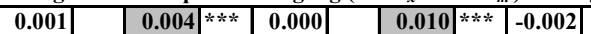

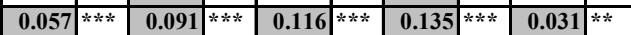

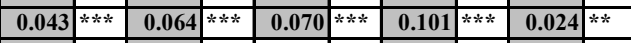

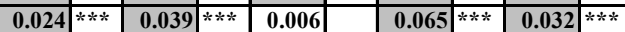

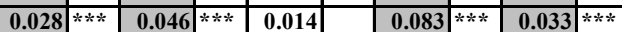

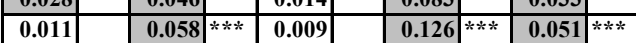

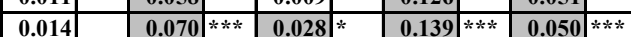

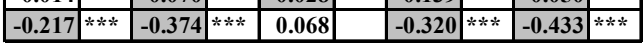

Introducing skills to land ratio into model

\begin{tabular}{|c|c|c|c|c|c|c|c|}
\hline \multicolumn{8}{|c|}{ o m } \\
\hline 0.000 & & \begin{tabular}{|l|}
-0.004 \\
\end{tabular} & $\% *$ & 0.010 & $* * *$ & \begin{tabular}{|c|}
-0.007 \\
\end{tabular} & $\% * *$ \\
\hline 0.052 & $\div \div$ & 0.052 & $\% * *$ & 0.119 & $* * *$ & 0.008 & \\
\hline 0.042 & $* * *$ & 0.023 & $\% *$ & 0.091 & $* * *$ & 0.012 & \\
\hline 0.041 & $\div * *$ & -0.015 & & 0.069 & $* * *$ & 0.056 & $* * *$ \\
\hline 0.050 & $\div * *$ & \begin{tabular}{|c|}
-0.009 \\
\end{tabular} & & 0.085 & $* * *$ & 0.061 & $* * *$ \\
\hline 0.015 & & \begin{tabular}{|c|}
-0.027 \\
\end{tabular} & & 0.058 & $* * *$ & 0.038 & $\approx *$ \\
\hline \begin{tabular}{|c|}
0.023 \\
\end{tabular} & & \begin{tabular}{|c|}
-0.007 \\
\end{tabular} & & 0.064 & $* * *$ & 0.039 & $* *$ \\
\hline \begin{tabular}{|c|}
-0.382 \\
\end{tabular} & $\approx * *$ & 0.024 & & -0.315 & $* * *$ & \begin{tabular}{|c|}
-0.458 \\
\end{tabular} & $\% * *$ \\
\hline
\end{tabular}

Restricting sample to countries for which skills to land ratio data is available but not introducing this ratio into model

\begin{tabular}{|c|c|c|c|c|c|c|c|}
\hline 0.003 & $\div \div$ & 0.001 & & 0.010 & $* * *$ & -0.003 & * \\
\hline 0.069 & $* * *$ & 0.087 & $* * *$ & 0.113 & $* * *$ & 0.031 & $* *$ \\
\hline 0.051 & $* * *$ & 0.043 & $* * *$ & 0.089 & $* * *$ & 0.024 & $* *$ \\
\hline 0.039 & $* * *$ & -0.015 & & 0.068 & $* * *$ & 0.055 & $* * *$ \\
\hline 0.048 & $* * *$ & \begin{tabular}{|c|c|}
-0.008 \\
\end{tabular} & & 0.084 & $* * *$ & 0.061 & $* * * *$ \\
\hline 0.020 & & -0.018 & & 0.066 & $* * *$ & 0.043 & ** \\
\hline 0.029 & “ & 0.004 & & 0.073 & $* * *$ & 0.045 & $\% *$ \\
\hline 0.333 & $\% *$ & 0.112 & & -0.304 & $* * *$ & -0.413 & $*$ \\
\hline
\end{tabular}

Using "residual" versions of indicators ${ }^{\#}$

\begin{tabular}{|r|c|c|c|r|l|l|l|l|l|}
\hline 0.049 & $* * *$ & 0.078 & $* * *$ & 0.101 & $* * *$ & 0.119 & $* * *$ & 0.014 & \\
\hline 0.042 & $* * *$ & 0.060 & $* * *$ & 0.065 & $* * *$ & 0.093 & $* * *$ & 0.018 & $*$ \\
\hline 0.000 & & 0.017 & $* *$ & -0.012 & & 0.041 & $* * *$ & 0.008 & \\
\hline 0.004 & & 0.022 & $* * *$ & -0.006 & & 0.057 & $* * *$ & 0.008 & \\
\hline-0.014 & & 0.031 & $* *$ & -0.025 & & 0.081 & $* * *$ & 0.031 & $*$ \\
\hline-0.010 & & 0.045 & $* * *$ & -0.007 & & 0.097 & $* * *$ & 0.032 & $*$ \\
\hline
\end{tabular}

Note: *** and $* * *$ indicate two-tailed significance at 10,5 and 1 percent levels, respectively.

Light shading indicates that stronger FACB rights are associated with significantly higher exports (10 percent level or higher),

while dark shading indicates that stronger FACB rights are associated with significantly lower exports.

\# "residual" versions of these indicators are the residuals from regressing these indicators on a constant, the ratio of total trade to GDP and this ratio squared. 
Table 5.C: Changes in total manufacturing exports associated with changes in democracy and FACB rights between example pairs of countries within regions

\begin{tabular}{|c|c|c|c|c|c|c|}
\hline Example countries from Latin America-Caribbean & $\begin{array}{l}\text { FH civil } \\
\text { liberties index }\end{array}$ & $\begin{array}{l}\text { FH political } \\
\text { rights index }\end{array}$ & $\begin{array}{l}\text { FACB index } \\
\text { unweighted }\end{array}$ & $\begin{array}{l}\text { FACB index } \\
\text { weighted }\end{array}$ & $\begin{array}{l}\text { OECD FACB } \\
\text { index } 1996\end{array}$ & $\begin{array}{l}\text { OECD FACB } \\
\text { index } 2000\end{array}$ \\
\hline A. Guatemala & 3.75 & 5.42 & 2.86 & 2.48 & 3.33 & 3.33 \\
\hline B. Uruguay & 8.33 & 8.75 & 8.57 & 8.65 & 10.00 & 10.00 \\
\hline$\%$ change in total mfg. exports associated with change in democracy and & & & & & & \\
\hline FACB rights from $\mathrm{A}$ to $\mathrm{B}$ & 35.56 & 20.00 & 9.59 & 13.79 & 20.75 & 30.17 \\
\hline $\begin{array}{l}\text { Change in } 1999 \text { total mfg. exports for country A associated with change in } \\
\text { democracy and FACB rights from A to B in millions of current US\$ }\end{array}$ & 494 & 278 & 133 & 192 & 288 & 419 \\
\hline \multicolumn{7}{|l|}{ Example countries from non-OECD East Asia-Pacific } \\
\hline A. Indonesia & 2.08 & 0.00 & 0.48 & 0.98 & 0.00 & 3.33 \\
\hline B. Thailand & 4.58 & 6.67 & 4.29 & 5.04 & 3.33 & 3.33 \\
\hline $\begin{array}{l}\% \text { change in total } \mathrm{mfg} \text {. exports associated with change in democracy and } \\
\text { FACB rights from A to B }\end{array}$ & 19.39 & 39.99 & 6.39 & 9.08 & 10.37 & 0.00 \\
\hline $\begin{array}{l}\text { Change in } 1999 \text { total mfg. exports for country A associated with change in } \\
\text { democracy and FACB rights from A to B in millions of current US\$ }\end{array}$ & 6,770 & 13,960 & 2,232 & 3,170 & 3,621 & $\underline{0}$ \\
\hline
\end{tabular}

\section{Example countries from South Asia}

\begin{tabular}{|c|c|c|c|c|c|c|}
\hline $\begin{array}{l}\text { A. Pakistan } \\
\text { B. India }\end{array}$ & 3.33 & $\begin{array}{l}6.25 \\
5.83\end{array}$ & $\begin{array}{l}1.43 \\
5.71\end{array}$ & $\begin{array}{l}2.78 \\
5.34\end{array}$ & $\begin{array}{l}3.33 \\
667\end{array}$ & $\begin{array}{l}3.33 \\
6.67\end{array}$ \\
\hline $\begin{array}{l}\text { B. India } \\
\% \text { change in total mfg. exports associated with change in democracy and }\end{array}$ & & & & & & \\
\hline FACB rights from $\mathrm{A}$ to $\mathrm{B}$ & 12.93 & -2.50 & 7.19 & 5.72 & 10.37 & 15.09 \\
\hline $\begin{array}{l}\text { Change in } 1999 \text { total mfg. exports for country A associated with change in } \\
\text { democracy and FACB rights from A to B in millions of current US\$ }\end{array}$ & 1,049 & -203 & 584 & 464 & 842 & 1,224 \\
\hline \multicolumn{7}{|l|}{ Example countries from Sub-Saharan Africa } \\
\hline $\begin{array}{l}\text { A. Zimbabwe } \\
\text { B. South Africa }\end{array}$ & $\begin{array}{ll}3.33 \\
7.08\end{array}$ & $\begin{array}{l}3.33 \\
7.92\end{array}$ & $\begin{array}{l}3.81 \\
5.71\end{array}$ & $\begin{array}{l}4.44 \\
5.49\end{array}$ & $\begin{array}{l}3.33 \\
6.67\end{array}$ & $\begin{array}{l}3.33 \\
6.67\end{array}$ \\
\hline $\begin{array}{l}\text { \% change in total mfg. exports associated with change in democracy and } \\
\text { FACB rights from A to B }\end{array}$ & 200 & & & & & 15.09 \\
\hline $\begin{array}{l}\text { Change in } 1999 \text { total mfg. exports for country A associated with change in } \\
\text { democracy and FACB rights from A to B in millions of current US\$ }\end{array}$ & 247 & 234 & 27 & 20 & 88 & 128 \\
\hline \multicolumn{7}{|l|}{ Example countries from Middle East-North Africa } \\
\hline $\begin{array}{l}\text { A. Syria } \\
\text { B. Jordan }\end{array}$ & $\begin{array}{l}0.00 \\
5.00\end{array}$ & $\begin{array}{l}0.00 \\
5.00\end{array}$ & $\begin{array}{l}0.00 \\
5.71\end{array}$ & $\begin{array}{l}0.00 \\
6.69\end{array}$ & $\begin{array}{l}0.00 \\
3.33\end{array}$ & 0.00 \\
\hline \% change in total mfg. exports associated with change in democracy and & & & & & & \\
\hline FACB rights from $A$ to $B$ & 38.79 & 30.00 & 9.59 & 14.97 & 10.37 & $15.0 \mathrm{~s}$ \\
\hline $\begin{array}{l}\text { Change in } 1999 \text { total mfg. exports for country A associated with change in } \\
\text { democracy and FACB rights from A to B in millions of current US\$ }\end{array}$ & 180 & 139 & 44 & 69 & 48 & \\
\hline
\end{tabular}

Note: Based on coefficient estimates for total mfg. trade from the lower right panel of table 5.B using "residual" versions of indicators and thus accounting for endogeneity with respect to de facto trade openness. Index values for Indonesia and South Africa are for these countries alone and not for the country groups defined in the data notes appendix. 
Table 5.D: Summary of main robust results for full sample of countries

\begin{tabular}{l|c|c|c|}
\multicolumn{1}{c}{} & \multicolumn{2}{c}{ Total mfg. } & \multicolumn{1}{c}{$\begin{array}{c}\text { Labour- } \\
\text { intensive } \\
\text { Total trade } \\
\text { trade }\end{array}$} \\
\cline { 2 - 4 } mfg. trade
\end{tabular}


Table 5.E: Regional breakdowns of total and labour-intensive manufacturing exports by percent shares: 1980-1999

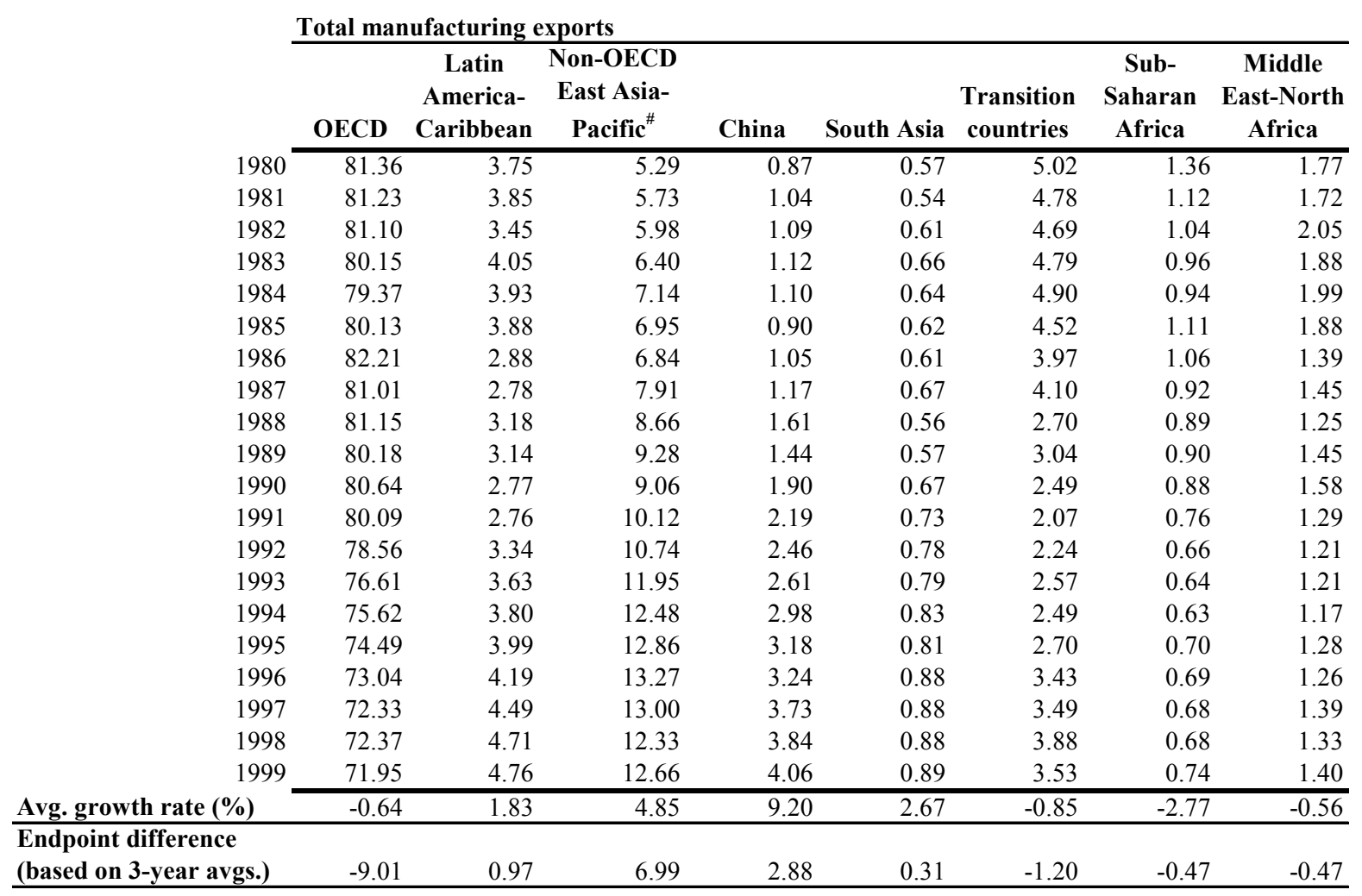

\begin{tabular}{|c|c|c|c|c|c|c|c|c|}
\hline & OECD & $\begin{array}{c}\text { Latin } \\
\text { America- } \\
\text { Caribbean }\end{array}$ & $\begin{array}{c}\text { Non-OECD } \\
\text { East Asia- } \\
\text { Pacific }^{\#}\end{array}$ & China & South Asia & $\begin{array}{l}\text { Transition } \\
\text { countries }\end{array}$ & $\begin{array}{c}\text { Sub- } \\
\text { Saharan } \\
\text { Africa }\end{array}$ & $\begin{array}{c}\text { Middle } \\
\text { East-North } \\
\text { Africa }\end{array}$ \\
\hline $1980^{\circ}$ & 72.41 & 2.78 & 12.36 & 2.84 & 2.30 & 5.08 & 0.46 & 1.77 \\
\hline 1981 & 70.24 & 2.77 & 13.77 & 3.50 & 2.26 & 5.20 & 0.38 & 1.88 \\
\hline 1982 & 69.92 & 2.54 & 14.35 & 3.66 & 2.34 & 5.03 & 0.40 & 1.75 \\
\hline 1983 & 69.15 & 2.88 & 14.67 & 3.96 & 2.67 & 4.72 & 0.38 & 1.58 \\
\hline 1984 & 67.27 & 3.20 & 16.34 & 3.91 & 2.71 & 4.66 & 0.30 & 1.61 \\
\hline 1985 & 68.32 & 3.05 & 16.31 & 3.09 & 2.60 & 4.59 & 0.56 & 1.49 \\
\hline 1986 & 68.27 & 2.49 & 16.91 & 3.73 & 2.51 & 4.19 & 0.51 & 1.38 \\
\hline 1987 & 66.01 & 2.55 & 19.00 & 3.93 & 2.74 & 3.97 & 0.42 & 1.38 \\
\hline 1988 & 65.64 & 2.64 & 19.66 & 5.07 & 2.30 & 2.92 & 0.48 & 1.30 \\
\hline 1989 & 63.93 & 2.64 & 20.96 & 4.80 & 2.42 & 2.97 & 0.65 & 1.65 \\
\hline 1990 & 64.96 & 2.38 & 19.62 & 5.54 & 2.71 & 2.47 & 0.64 & 1.69 \\
\hline 1991 & 62.78 & 2.35 & 21.40 & 6.41 & 2.91 & 2.18 & 0.49 & 1.48 \\
\hline 1992 & 59.94 & 3.08 & 21.47 & 7.76 & 3.00 & 2.75 & 0.58 & 1.43 \\
\hline 1993 & 57.70 & 3.29 & 22.50 & 8.23 & 3.00 & 3.18 & 0.59 & 1.52 \\
\hline 1994 & 56.70 & 3.30 & 21.47 & 9.33 & 3.22 & 3.84 & 0.55 & 1.60 \\
\hline 1995 & 56.88 & 3.53 & 20.95 & 9.20 & 3.03 & 4.14 & 0.64 & 1.62 \\
\hline 1996 & 56.53 & 3.52 & 20.96 & 9.18 & 3.37 & 4.21 & 0.71 & 1.51 \\
\hline 1997 & 55.70 & 3.94 & 19.79 & 10.59 & 3.32 & 4.29 & 0.81 & 1.55 \\
\hline 1998 & 55.65 & 4.43 & 18.26 & 10.60 & 3.51 & 4.91 & 0.83 & 1.82 \\
\hline 1999 & 54.76 & 4.54 & 18.78 & 10.99 & 3.63 & 4.70 & 0.85 & 1.74 \\
\hline Avg. growth rate (\%) & -1.44 & 3.12 & 2.40 & 8.04 & 2.69 & 0.37 & 5.53 & 0.34 \\
\hline $\begin{array}{l}\text { Endpoint difference } \\
\text { (based on 3-year avgs.) }\end{array}$ & -15.49 & 1.61 & 5.45 & 7.39 & 1.19 & -0.47 & 0.42 & -0.10 \\
\hline
\end{tabular}

Source: World Trade Analyzer, 1980-1999.

Note: " Excludes China.

*Using authors' industry classification, shown in table 4.A. 
Table 5.F: Trade model results on separate regional dummy variables for China and other non-OECD East Asia-Pacific

Labour-

Capital-

\begin{tabular}{|c|c|c|c|c|c|}
\hline & Total trade & Total mfg. trade & $\begin{array}{l}\text { Labour- } \\
\text { intensive mfg. } \\
\text { trade }\end{array}$ & $\begin{array}{c}\text { In-between mfg. } \\
\text { trade }\end{array}$ & $\begin{array}{c}\text { Capital- } \\
\text { intensive mfg. } \\
\text { trade }\end{array}$ \\
\hline Authors' industry classification, w/ regional dummy variables & \multicolumn{5}{|c|}{ From benchmark model } \\
\hline Coefficient estimates on China export dummy & \begin{tabular}{|l|l|l|}
1.391 & $* * *$ \\
\end{tabular} & \begin{tabular}{l|l|l|}
1.963 & $* * *$ \\
\end{tabular} & \begin{tabular}{l|l|l|}
2.865 & $* * *$ \\
\end{tabular} & \begin{tabular}{|l|l|}
2.152 & $* * *$ \\
\end{tabular} & \begin{tabular}{|l|l|l|l}
1.340 & $* * *$ \\
\end{tabular} \\
\hline Coefficient estimates on China import dummy & -0.157 & \begin{tabular}{l|l|l}
-0.448 & $* *$ \\
\end{tabular} & $-0.442 \mid * *$ & -0.102 & -0.443 * \\
\hline Authors' industry classification, w/ regional dummy variables & \multicolumn{5}{|c|}{ From benchmark model } \\
\hline Coefficient estimates on other non-OECD East Asia-Pacific export dummy & \begin{tabular}{|l|l|l|}
1.118 & $* * *$ \\
\end{tabular} & \begin{tabular}{l|l|l|}
1.303 & $* * *$ \\
\end{tabular} & \begin{tabular}{|l|l|}
1.962 & $* * *$ \\
\end{tabular} & \begin{tabular}{l|l|l|}
1.105 & $* * *$ \\
\end{tabular} & \begin{tabular}{l|l|l|l}
0.747 & $* * *$ \\
\end{tabular} \\
\hline Coefficient estimates on other non-OECD East Asia-Paci & $\mathbf{0 . 1 2 0}$ & \begin{tabular}{c|c|c|}
0.226 & $* * *$ \\
\end{tabular} & \begin{tabular}{l|l|l|l}
-0.139 & $*$ \\
\end{tabular} & \begin{tabular}{l|l|l|}
$\mathbf{0 . 7 8 7}$ & $* * *$ \\
\end{tabular} & \begin{tabular}{l|l|l}
0.443 & $* * *$ \\
\end{tabular} \\
\hline
\end{tabular}

Note: $* * *$ and $* * *$ indicate two-tailed significance at 10,5 and 1 percent levels, respectively. 


\section{Table 5.G: Trade model results with respect to dropping one region at a time from the sample}

\begin{tabular}{|c|c|c|c|c|c|c|c|c|c|c|c|c|c|c|c|c|c|c|}
\hline \multirow{2}{*}{$\begin{array}{l}\text { Authors' industry } \\
\text { classification, w/ regional } \\
\text { dummy variables }\end{array}$} & otal trade & \multicolumn{2}{|c|}{$\begin{array}{c}\text { Total mfg. } \\
\text { trade }\end{array}$} & \multicolumn{2}{|c|}{$\begin{array}{l}\text { Labour- } \\
\text { intensive } \\
\text { mfg. trade }\end{array}$} & $\begin{array}{l}\text { In-between } \\
\text { mfg. trade }\end{array}$ & \multicolumn{2}{|c|}{$\begin{array}{c}\text { Capital- } \\
\text { intensive } \\
\text { mfg. trade } \\
\end{array}$} & \multicolumn{2}{|c|}{ Total trade } & \multicolumn{2}{|c|}{$\begin{array}{l}\text { Total mfg. } \\
\text { trade }\end{array}$} & \multicolumn{2}{|c|}{$\begin{array}{c}\text { Labour- } \\
\text { intensive } \\
\text { mfg. trade }\end{array}$} & \multicolumn{2}{|c|}{$\begin{array}{l}\text { In-between } \\
\text { mfg. trade }\end{array}$} & \multicolumn{2}{|c|}{$\begin{array}{c}\text { Capital- } \\
\text { intensive } \\
\text { mfg. trade }\end{array}$} \\
\hline & \multicolumn{8}{|c|}{$\begin{array}{l}\text { Dropping OECD from the sample (and dropping dummy } \\
\text { variables for Latin America-Caribbean from model) }\end{array}$} & \multicolumn{10}{|c|}{ Dropping Latin America-Caribbean from the sample } \\
\hline Unionization rate $_{x}$ & \begin{tabular}{|l|l|}
0.008 & $* * *$ \\
\end{tabular} & 0.010 & $\% * *$ & 0.009 & $\% * *$ & \begin{tabular}{|l|l|}
0.015 & $* * *$ \\
\end{tabular} & 0.000 & & 0.001 & & 0.004 & $* *$ & 0.003 & & 0.008 & $* * *$ & -0.003 & * \\
\hline FH civil liberties index $x_{x}$ & \begin{tabular}{l|l|l|}
0.051 & $* * *$ \\
\end{tabular} & 0.080 & $* * *$ & 0.105 & $* * *$ & $\begin{array}{l}0.096 \\
\end{array}$ & 0.019 & & 0.033 & $* * *$ & 0.071 & $* * *$ & 0.093 & $* * *$ & 0.112 & $* * *$ & 0.010 & \\
\hline FH political rights index $_{x}$ & \begin{tabular}{|l|l|}
0.048 & $* * *$ \\
\end{tabular} & 0.065 & $\% * *$ & 0.063 & $* * *$ & $\begin{array}{l}0.078 \\
\end{array}$ & 0.017 & & 0.018 & * & 0.044 & $* * *$ & 0.052 & $* * *$ & 0.073 & $* * *$ & 0.004 & \\
\hline$F A C B$ index unweighted $d_{x}$ & \begin{tabular}{|l|l|}
0.031 & $* * *$ \\
\end{tabular} & 0.050 & $\% * *$ & 0.021 & 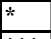 & \begin{tabular}{|l|l|}
$\mathbf{0 . 0 7 3}$ & $* * *$ \\
\end{tabular} & 0.050 - & & 0.019 & $* *$ & 0.033 & $* * *$ & 0.006 & & 0.068 & $* * *$ & 0.018 & * \\
\hline FACB index weighted $_{x}$ & \begin{tabular}{|l|l|}
0.038 & $* * *$ \\
\end{tabular} & 0.057 & $\% * *$ & 0.032 & $* * *$ & \begin{tabular}{|l|l|}
0.087 & $* * *$ \\
\end{tabular} & 0.050 * & $* * *$ & 0.017 " & & 0.032 & $* * *$ & 0.004 & & 0.079 & $* * *$ & 0.014 & \\
\hline OECD FACB index $1996_{x}$ & \begin{tabular}{l|l}
0.011 \\
\end{tabular} & 0.072 & $\div \div *$ & 0.011 & & \begin{tabular}{|l|l|}
0.121 & $* * *$ \\
\end{tabular} & 0.077 * & $* * *$ & -0.026 & & 0.000 & & -0.067 & $\div \div *$ & 0.108 & $* * *$ & 0.007 & \\
\hline$O E C D$ FACB index $2000_{x}$ & 0.012 & 0.072 & $\% * *$ & $\mathbf{0 . 0 2 0}$ & & \begin{tabular}{|l|l|}
0.126 & $* * *$ \\
\end{tabular} & 0.058 * & ** & -0.031 & * & 0.004 & & -0.053 & $\% * *$ & 0.122 & $* * *$ & 0.002 & \\
\hline$F A C B$ in $E P Z s_{x}$ & \begin{tabular}{|l|l|}
-0.183 & $* * * *$ \\
\end{tabular} & -0.310 & $\% * *$ & 0.106 & & \begin{tabular}{l|l|l|}
-0.180 & $* *$ \\
\end{tabular} & -0.413 & $* * *$ & -0.241 & $* * *$ & -0.323 & $* * *$ & 0.300 & $* * *$ & -0.343 & $* * *$ & -0.408 & $* * *$ \\
\hline
\end{tabular}

Authors' industry

classification, $w /$ regional dummy variables

Dropping South Asia from the sample

Unionization rate ${ }_{x}$

FH civil liberties inde $x_{x}$

FH political rights index $x_{x}$

FACB index unweighted

$F A C B$ index weighted $x$

OECD FACB index 1996 x

OECD FACB index $2000_{x}$

$F A C B$ in $E P Z s_{x}$

\begin{tabular}{|c|c|c|c|c|c|c|c|c|c|}
\hline \multicolumn{10}{|c|}{ Dropping South Asia from the sample } \\
\hline 0.000 & & 0.005 & $\div * *$ & 0.001 & & 0.009 & $* * *$ & \begin{tabular}{|c|}
-0.001 \\
\end{tabular} & \\
\hline 0.082 & $* * *$ & 0.112 & $\div * *$ & 0.138 & $\because \div$ & 0.162 & $* * *$ & 0.049 & $\% * *$ \\
\hline 0.058 & $\% * *$ & 0.077 & $* * *$ & 0.078 & $\% * *$ & 0.127 & $* * *$ & 0.045 & $\% * *$ \\
\hline 0.029 & $* * *$ & 0.047 & $\div * *$ & 0.010 & & 0.063 & $* * *$ & 0.037 & $\% * *$ \\
\hline 0.032 & $* * *$ & 0.051 & $\div * *$ & 0.014 & & 0.084 & $* * *$ & 0.038 & $\% * *$ \\
\hline 0.035 & $\% *$ & 0.076 & $\div * *$ & 0.030 & * & 0.132 & $\% * *$ & 0.030 & \\
\hline 0.038 & $* *$ & 0.088 & $\div * *$ & 0.047 & $\% * *$ & 0.144 & $* * *$ & 0.026 & \\
\hline-0.300 & $* * *$ & -0.425 & $\% \div *$ & -0.002 & & -0.315 & *** & -0.421 & $\% * *$ \\
\hline
\end{tabular}

Dropping Middle East-North Africa from the sample

\begin{tabular}{|c|c|c|c|c|c|c|c|c|}
\hline 0.002 & & 0.006 & $* * *$ & 0.000 & & 0.010 & $T * * *$ & \begin{tabular}{ll|}
0.000 \\
\end{tabular} \\
\hline 0.054 & $* * *$ & 0.069 & $* * *$ & 0.107 & $\div * *$ & 0.078 & $\div * *$ & 0.023 \\
\hline 0.040 & $\% * *$ & 0.053 & $\% * *$ & 0.068 & $\div * *$ & 0.060 & $\% * *$ & 0.025 \\
\hline 0.021 & ** & 0.020 & $* *$ & -0.008 & & 0.020 & $\div *$ & 0.016 \\
\hline 0.024 & *** & |0.021 & *** & \begin{tabular}{|c|c|}
-0.003 \\
\end{tabular} & & 0.028 & $* * *$ & \begin{tabular}{c|}
0.009 \\
\end{tabular} \\
\hline-0.049 & $\% * *$ & -0.018 & & -0.063 & $\div * *$ & 0.000 & & 0.005 \\
\hline-0.053 & $\% * \%$ & -0.011 & & -0.048 & ** & -0.006 & & -0.004 \\
\hline 0.129 & $\% *$ & -0.216 & $* * *$ & 0.145 & $\% *$ & \begin{tabular}{|l|}
-0.151 \\
\end{tabular} & $1 \% *$ & -0.245 \\
\hline
\end{tabular}

Authors' industry

classification, $w /$ regional

dummy variables

Dropping Transition countries from the sample

Unionization rate $x$

FH civil liberties index $x_{x}$

FH political rights index $x_{x}$

FACB index unweighted

$F A C B$ index weighted $x$

OECD FACB index 1996,

OECD FACB index $2000_{x}$

$F A C B$ in $E P Z s_{x}$

\begin{tabular}{|c|c|c|c|c|c|c|c|c|c|}
\hline \multicolumn{10}{|c|}{ Dropping Transition countries from the sample } \\
\hline-0.001 & & 0.003 & ** & $\mathbf{0 . 0 0 0}$ & & 0.011 & *** & -0.004 & *** \\
\hline 0.052 & $* * *$ & 0.082 & $* * *$ & 0.108 & $* * *$ & 0.124 & $* * *$ & 0.020 & \\
\hline 0.045 & $* * *$ & 0.064 & $\div * *$ & 0.067 & $\div \div \%$ & 0.096 & $\% * *$ & 0.022 & $\% *$ \\
\hline 0.027 & $* * *$ & 0.041 & **** & 0.012 & & 0.070 & $* * *$ & 0.029 & $* * *$ \\
\hline 0.032 & $* * *$ & 0.048 & $2 * * *$ & 0.019 & $* *$ & 0.086 & $* * *$ & $\mathbf{0 . 0 3 0}$ & $* * *$ \\
\hline 0.011 & & 0.056 & *** & 0.008 & & 0.122 & $* * *$ & 0.042 & ** \\
\hline 0.015 & & 0.068 & **** & 0.026 & & 0.135 & $* * *$ & 0.040 & ** \\
\hline-0.232 & $* * *$ & -0.374 & $\div * *$ & 0.076 & & -0.322 & $* * *$ & -0.446 & $* * *$ \\
\hline
\end{tabular}

Dropping non-OECD East Asia-Pacific (including China) from the sample

\begin{tabular}{|c|c|c|c|c|c|c|c|c|c|}
\hline 0.002 & & 0.003 & $* *$ & 33 & & 0.010 & 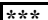 & -0.003 & \\
\hline 0.082 & $\pi * *$ & 0.110 & $* * *$ & 0.140 & $\% * * *$ & 0.146 & $* * *$ & \begin{tabular}{|c|}
0.048 \\
\end{tabular} & $\% * *$ \\
\hline 0.059 & $\% * *$ & 0.077 & $\% * *$ & $\overline{0.095}$ & $\% * *$ & 0.112 & $\% * *$ & 0 & $\% *$ \\
\hline 0.034 & $\% * *$ & 0.048 & $* * *$ & 0.012 & & \begin{tabular}{|c|}
0.073 \\
\end{tabular} & $\% * *$ & 0.033 & $\% * *$ \\
\hline $\begin{array}{l}0.037 \\
\end{array}$ & $\% * *$ & 0.054 & $* * *$ & 0.022 & $\% *$ & 0.085 & $\% * *$ & 0.031 & $\% * *$ \\
\hline 0.045 & $\% * *$ & 0.093 & $* * *$ & 0.027 & & 0.172 & $* * *$ & 0.074 & $\% * *$ \\
\hline 0.051 & $\% * *$ & 0.109 & $\% * *$ & 0.044 & $\% *$ & 0.192 & $* * *$ & \begin{tabular}{|c|}
0.087 \\
\end{tabular} & $\% * *$ \\
\hline-0.008 & & $\begin{array}{c}-194 \\
\end{array}$ & $\% * *$ & 0.284 & $\% * *$ & -0.265 & $\% * *$ & -0.365 & $\% * *$ \\
\hline
\end{tabular}

Authors' industry

classification, $w /$ regional

dummy variables

Dropping Sub-Saharan Africa from the sample

Unionization rate

FH civil liberties index $x_{x}$

FH political rights index

FACB index unweighted

$F A C B$ index weighted $x$

OECD FACB index 1996

OECD FACB index $2000_{x}$

$F A C B$ in $E P Z s_{x}$

\begin{tabular}{|c|c|c|c|c|c|c|c|c|c|}
\hline \multicolumn{10}{|c|}{ Dropping Sub-Saharan } \\
\hline-0.002 & & 0.000 & & -0.002 & & 0.010 & $\% * *$ & -0.004 & $\% * *$ \\
\hline 0.066 & $* * *$ & 0.098 & $\div * *$ & 0.101 & $\% *$ & 0.152 & $\% * *$ & 0.031 & $\% *$ \\
\hline 0.056 & $\% * *$ & 0.066 & $\% * *$ & 0.055 & $\% * *$ & 0.107 & $* * *$ & 0.020 & \\
\hline 0.023 & $* *$ & 0.040 & $\% * *$ & 0.004 & & 0.064 & $\% * *$ & 0.023 & ** \\
\hline 0.031 & $* * *$ & 0.054 & $\div * *$ & 0.015 & & 0.086 & $\% * *$ & 0.029 & *** \\
\hline $\mathbf{0 . 0 2 7}$ & & 0.080 & $\div * *$ & 0.062 & $* * *$ & 0.140 & $* * *$ & 0.075 & $* * *$ \\
\hline 0.033 & * & 0.095 & $\% \div *$ & 0.085 & $* \div *$ & 0.157 & $\% * *$ & 0.074 & $* * *$ \\
\hline-0.105 & & -0.392 & $\% \div *$ & -0.229 & $\% * *$ & -0.313 & $* * *$ & -0.378 & $\% * *$ \\
\hline
\end{tabular}

\begin{tabular}{|c|c|c|c|c|c|c|c|c|c|}
\hline \multicolumn{10}{|c|}{ Dropping China from the sample } \\
\hline 0.000 & & 0.002 & & -0.004 & $\div *$ & 0.009 & $\% * *$ & 0.005 & $* * *$ \\
\hline 0.061 & $* * *$ & 0.094 & $* * *$ & 0.120 & $\% * *$ & 0.135 & $\% * *$ & 0.031 & $\% *$ \\
\hline 0.047 & $* * *$ & 0.068 & *** & 0.075 & $\% * *$ & 0.103 & $\% * *$ & 0.026 & $\% *$ \\
\hline 0.026 & $\% * *$ & $\overline{0.041}$ & $* * *$ & 0.008 & & 0.065 & $\% * \%$ & 0.030 & $\% * \%$ \\
\hline 0.031 & $* * *$ & 0.048 & $* * *$ & 0.017 & $\%$ & 0.083 & $\div * *$ & 0.032 & $\% * *$ \\
\hline 0.012 & & 0.062 & $* * *$ & 0.009 & & 0.125 & $\div \div \%$ & 0.050 & $* * *$ \\
\hline $\begin{array}{l}0.017 \\
\end{array}$ & & 0.079 & $* * *$ & 0.034 & $\div *$ & 0.146 & $* \ldots *$ & 0.053 & $\% * *$ \\
\hline-0.230 & $* * *$ & -0.410 & $* * *$ & 0.019 & & -0.391 & $\% * *$ & -0.479 & $\% * *$ \\
\hline
\end{tabular}

Note: *,* and *** indicate two-tailed significance at 10,5 and 1 percent levels, respectively.

Light shading indicates that stronger FACB rights are associated with significantly higher exports (10 percent level or higher),

while dark shading indicates that stronger FACB rights are associated with significantly lower exports. 

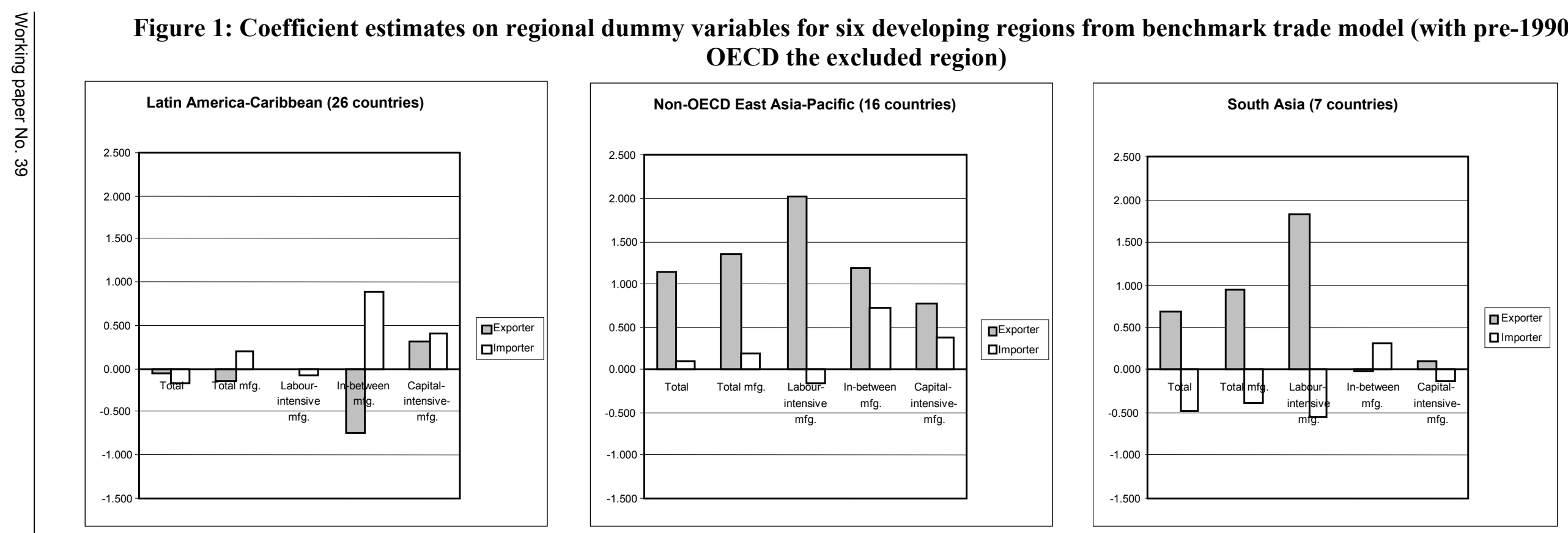

Transition countries (8 countries)
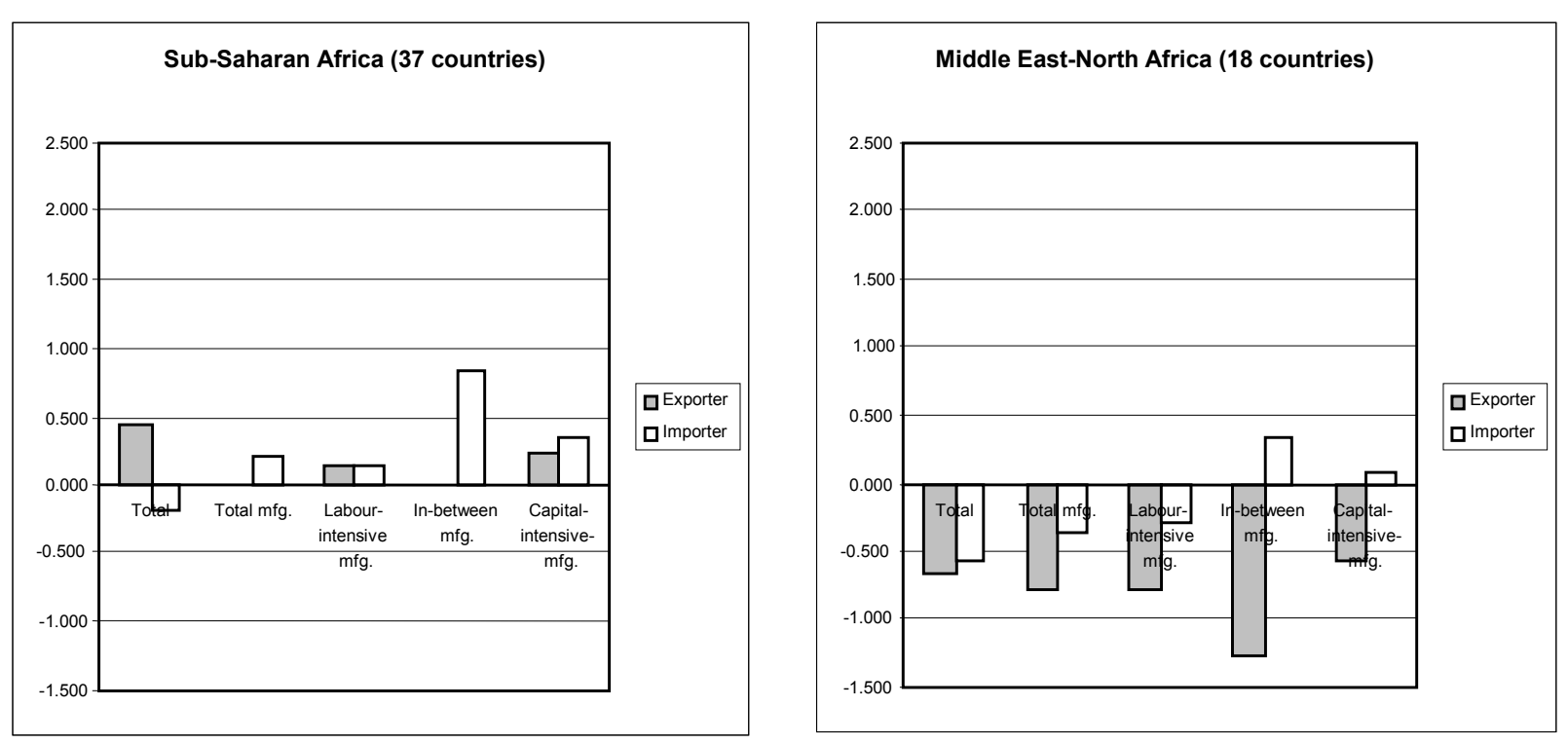
ISIC Rev. 2 by author's

industry classification SITC Rev. 2 (as per World Trade Analyzer database)

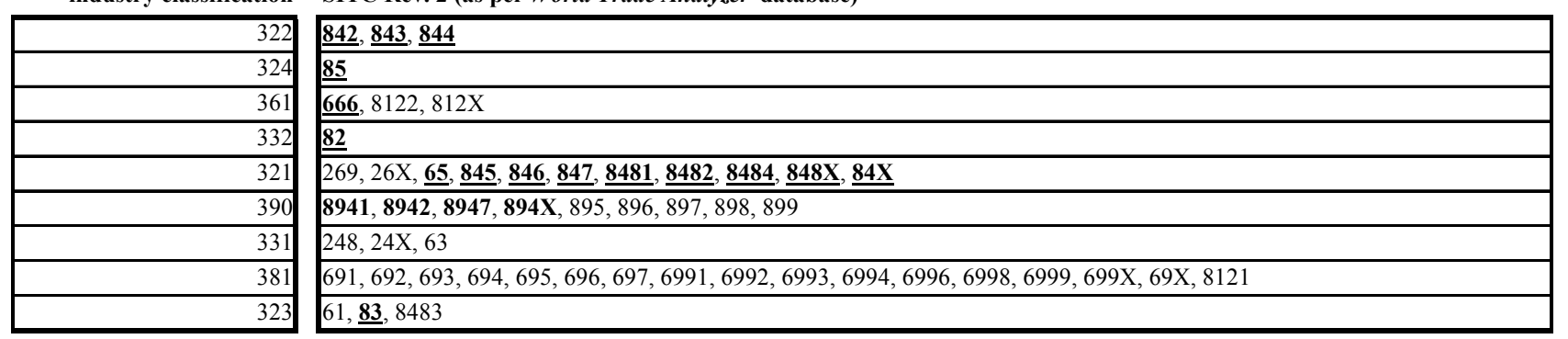

\begin{tabular}{|c|c|}
\hline 342 & 892 \\
\hline 385 & $87,881,884,885,88 \mathrm{X}$ \\
\hline 362 & $\underline{664}, \underline{65}$ \\
\hline 355 & 233,62 \\
\hline 356 & 893 \\
\hline 382 minus 3825 & $\begin{array}{l}711,712,7138,7139,713 \mathrm{X}, 714,718,71 \mathrm{X}, 72,736,7371,7372,737 \mathrm{X}, 73 \mathrm{X}, 7411,7412,7414,7415,7416,741 \mathrm{X}, 742,743, \\
744,745,749,74 \mathrm{X}, 7751,7752,7753,7758,775 \mathrm{X}, 7784, \mathbf{8 9 4 6}, 95\end{array}$ \\
\hline 369 & $661, \underline{662}, \underline{663}, \underline{66 \mathrm{X}}$ \\
\hline 383 minus 3832 & $716,7373,7413,771,772,773,774,7754,7757,776,7781,7782,7783,7788,778 X, 77 X, 8124$ \\
\hline 3825 plus 3832 & 75,76 \\
\hline 384 & $7131,7132,7133,78,79$ \\
\hline 341 & 25,64 \\
\hline
\end{tabular}

\begin{tabular}{|c|c|}
\hline 311 plus 312 & \begin{tabular}{|l|l}
$01,0224,023,024,0342,0344,035,037,03 X, 0422,046,047,048,04 X, 0546,056,0583,0585,0586,0589,058 X, 05 X$, \\
$0611,0612,0615,0619,062,0722,0723,073,091,098,09 X, 4$ (ISIC 311); 0712, 0812, 0813, 0814, 0819, 081X (ISIC 312)
\end{tabular} \\
\hline 352 & $5332,5334,5335,533 \mathrm{X}, 54,5513,551 \mathrm{X}, 553,554,55 \mathrm{X}, 57,882,883$ \\
\hline 371 & 67,6997 \\
\hline 372 & 68 \\
\hline 354 & $323,32 X, 3352,3353$ \\
\hline 313 & 11 \\
\hline 314 & 122 \\
\hline 351 & $266,267,274,51,52,531,532,5331,53 \mathrm{X}, 5514,56,58,59,5 \mathrm{X}$ \\
\hline 353 & $334,3351,3354,3359,335 \mathrm{X}$ \\
\hline
\end{tabular}

Note: "X" is used on the World Trade Analyzer database to indicate "not elsewhere classified."

When an SITC industry contains both manufactures and non-manufactures, we exclude it from manufacturing and the above table.

Regarding SITC, underlined and bolded figures represent, respectively, Krause's and Busse's less-skilled labour intensive industry groups,

with industries in both groups being both underlined and bolded. 


\section{Appendix Table 2: Regional breakdowns of in-between and capital-intensive manufacturing exports by percent shares: 1980-1999}

\begin{tabular}{|c|c|c|c|c|c|c|c|c|}
\hline & \multicolumn{8}{|c|}{ In-between manufacturing exports ${ }^{*}$} \\
\hline & OECD & $\begin{array}{c}\text { Latin } \\
\text { America- } \\
\text { Caribbean }\end{array}$ & $\begin{array}{c}\text { Non-OECD } \\
\text { East Asia- } \\
\text { Pacific }^{\#}\end{array}$ & China & South Asia & $\begin{array}{l}\text { Transition } \\
\text { countries }\end{array}$ & $\begin{array}{c}\text { Sub- } \\
\text { Saharan } \\
\text { Africa } \\
\end{array}$ & $\begin{array}{c}\text { Middle } \\
\text { East-North } \\
\text { Africa } \\
\end{array}$ \\
\hline $1980^{\circ}$ & 89.76 & 1.28 & 3.28 & 0.18 & 0.15 & 3.96 & 0.88 & 0.49 \\
\hline 1981 & 89.69 & 1.39 & 3.49 & 0.22 & 0.12 & 3.79 & 0.68 & 0.63 \\
\hline 1982 & 89.65 & 1.26 & 3.86 & 0.21 & 0.16 & 3.61 & 0.63 & 0.63 \\
\hline 1983 & 88.73 & 1.63 & 4.56 & 0.22 & 0.13 & 3.62 & 0.56 & 0.55 \\
\hline 1984 & 88.15 & 1.62 & 5.24 & 0.27 & 0.14 & 3.47 & 0.56 & 0.55 \\
\hline 1985 & 88.45 & 1.75 & 5.04 & 0.13 & 0.14 & 3.44 & 0.62 & 0.44 \\
\hline 1986 & 89.66 & 1.17 & 4.76 & 0.18 & 0.13 & 3.13 & 0.58 & 0.40 \\
\hline 1987 & 88.58 & 1.43 & 5.81 & 0.23 & 0.12 & 2.92 & 0.50 & 0.40 \\
\hline 1988 & 88.26 & 1.60 & 6.79 & 0.66 & 0.12 & 1.72 & 0.45 & 0.41 \\
\hline 1989 & 87.78 & 1.58 & 7.20 & 0.45 & 0.08 & 1.99 & 0.48 & 0.44 \\
\hline 1990 & 87.86 & 1.42 & 7.16 & 0.98 & 0.14 & 1.48 & 0.48 & 0.48 \\
\hline 1991 & 87.19 & 1.46 & 8.16 & 1.18 & 0.13 & 1.00 & 0.42 & 0.45 \\
\hline 1992 & 85.27 & 2.48 & 8.90 & 1.13 & 0.14 & 1.17 & 0.41 & 0.50 \\
\hline 1993 & 82.99 & 2.80 & 10.51 & 1.26 & 0.15 & 1.33 & 0.41 & 0.54 \\
\hline 1994 & 81.38 & 2.99 & 11.68 & 1.48 & 0.16 & 1.32 & 0.40 & 0.58 \\
\hline 1995 & 80.02 & 3.07 & 12.53 & 1.76 & 0.16 & 1.47 & 0.41 & 0.58 \\
\hline 1996 & 78.52 & 3.37 & 13.11 & 1.94 & 0.18 & 1.84 & 0.47 & 0.58 \\
\hline 1997 & 77.82 & 3.75 & 12.86 & 2.24 & 0.18 & 2.04 & 0.46 & 0.65 \\
\hline 1998 & 77.30 & 4.12 & 12.17 & 2.48 & 0.16 & 2.62 & 0.47 & 0.68 \\
\hline 1999 & 76.48 & 4.43 & 12.52 & 2.78 & 0.16 & 2.49 & 0.44 & 0.69 \\
\hline Avg. growth rate (\%) & -0.83 & 8.37 & 7.62 & 23.19 & 2.42 & -0.64 & -3.18 & 2.25 \\
\hline $\begin{array}{l}\text { Endpoint difference } \\
\text { (based on 3-year avgs.) }\end{array}$ & -12.50 & 2.79 & 8.97 & 2.30 & 0.03 & -1.40 & -0.27 & 0.09 \\
\hline
\end{tabular}

\begin{tabular}{|c|c|c|c|c|c|c|c|c|}
\hline & \multicolumn{8}{|c|}{ Capital-intensive manufacturing exports" } \\
\hline & OECD & $\begin{array}{c}\text { Latin } \\
\text { America- } \\
\text { Caribbean }\end{array}$ & $\begin{array}{c}\text { Non-OECD } \\
\text { East Asia- } \\
\text { Pacific }^{\#}\end{array}$ & China & South Asia & $\begin{array}{l}\text { Transition } \\
\text { countries }\end{array}$ & $\begin{array}{c}\text { Sub- } \\
\text { Saharan } \\
\text { Africa }\end{array}$ & $\begin{array}{c}\text { Middle } \\
\text { East-North } \\
\text { Africa }\end{array}$ \\
\hline 1980 & 74.37 & 7.39 & 4.81 & 0.89 & 0.36 & 6.37 & 2.38 & 3.43 \\
\hline 1981 & 74.40 & 7.73 & 5.24 & 1.07 & 0.37 & 5.98 & 2.06 & 3.16 \\
\hline 1982 & 74.09 & 6.94 & 5.20 & 1.17 & 0.46 & 6.05 & 1.90 & 4.18 \\
\hline 1983 & 72.83 & 8.06 & 5.25 & 1.12 & 0.52 & 6.49 & 1.81 & 3.92 \\
\hline 1984 & 71.90 & 7.67 & 5.75 & 1.05 & 0.44 & 7.12 & 1.79 & 4.28 \\
\hline 1985 & 72.69 & 7.59 & 5.55 & 1.09 & 0.44 & 6.18 & 2.14 & 4.32 \\
\hline 1986 & 76.55 & 6.15 & 5.02 & 1.12 & 0.41 & 5.37 & 2.21 & 3.16 \\
\hline 1987 & 76.02 & 5.34 & 5.25 & 1.25 & 0.44 & 6.32 & 1.98 & 3.39 \\
\hline 1988 & 76.97 & 6.39 & 5.80 & 1.39 & 0.39 & 4.38 & 1.92 & 2.76 \\
\hline 1989 & 75.61 & 6.32 & 6.33 & 1.31 & 0.40 & 5.03 & 1.81 & 3.19 \\
\hline 1990 & 76.50 & 5.59 & 6.18 & 1.43 & 0.44 & 4.42 & 1.80 & 3.64 \\
\hline 1991 & 77.13 & 5.56 & 6.81 & 1.49 & 0.50 & 4.10 & 1.60 & 2.79 \\
\hline 1992 & 77.55 & 5.31 & 7.18 & 1.54 & 0.55 & 4.11 & 1.23 & 2.52 \\
\hline 1993 & 76.44 & 5.56 & 7.66 & 1.54 & 0.58 & 4.70 & 1.14 & 2.38 \\
\hline 1994 & 76.40 & 5.87 & 7.97 & 1.80 & 0.60 & 4.05 & 1.19 & 2.12 \\
\hline 1995 & 74.26 & 6.22 & 8.30 & 2.25 & 0.74 & 4.36 & 1.32 & 2.56 \\
\hline 1996 & 72.06 & 6.38 & 8.61 & 2.15 & 0.76 & 6.34 & 1.16 & 2.54 \\
\hline 1997 & 71.47 & 6.49 & 8.76 & 2.38 & 0.77 & 6.13 & 1.08 & 2.91 \\
\hline 1998 & 72.42 & 6.25 & 8.66 & 2.35 & 0.73 & 6.05 & 1.06 & 2.48 \\
\hline 1999 & 72.93 & 5.70 & 8.75 & 2.34 & 0.76 & 5.24 & 1.39 & 2.88 \\
\hline Avg. growth rate (\%) & -0.09 & -0.92 & 3.34 & 5.55 & 4.58 & 0.21 & -2.08 & 0.34 \\
\hline $\begin{array}{l}\text { Endpoint difference } \\
\text { (based on 3-year avgs.) }\end{array}$ & -2.01 & -1.21 & 3.64 & 1.31 & 0.36 & -0.32 & -0.94 & -0.83 \\
\hline
\end{tabular}

Source: World Trade Analyzer, 1980-1999.

Note: ${ }^{\#}$ Excludes China.

"Using authors' industry classification, shown in table 4.A. 


\section{Appendix: Data Sources}

Trade data: Statistics Canada, World Trade Analyzer, 1980-1999.

Area and geographic center of countries and whether they share a common border, are landlocked or are an island: CIA, The World Factbook 2000, www.cia.gov/cia/publications/factbook

Unionization rate: ILO, ILO World Labour Report, 1997-98 (for Sri Lanka and Syrian Arab Republic, constructed from ILO Statistics of Trade Union Membership and ILO Yearbook of Labour Statistics, 1999).

Freedom House indices: Freedom House, www.freedomhouse.org

FACB indices: Constructed by authors.

OECD indices: OECD, Trade, Employment and Labour Standards: A Study of Core Workers' Rights and International Trade, Paris; OECD; 1996; International Trade and Core Labour Standards, Paris; OECD, 2000.

Manufacturing value-added, output and employment: UNIDO, UNIDO Industrial Statistics Database, 2001 (output and employment data for Denmark is from the 2000 edition, as they are not available in the 2001 edition).

Exchange rates: IMF, IMF International Financial Statistics, version 1.1.54, February 2002.

Regional trade agreements. World Trade Organization, www.wto.org

Average years of educational attainment for adults (aged fifteen or older): Barro and Lee data for 1995, human capital updated files, April 2000. Center for International Development, Harvard University. Additional country observations for 1990 were added to the Barro and Lee data and were generously provided by Jörg Mayer and Adrian Wood. These data are for Angola, Bangladesh, Burkina Faso, Canada, Chad, Comoros, Côte d'Ivoire, Equatorial Guinea, Ethiopia, Gabon, Guinea, Madagascar, Morocco, Nigeria, Oman, Saudi Arabia and the United Arab Emirates.

All other data: World Bank, World Development Indicators, 2001. 


\section{Appendix: Data Notes}

Eight "countries" in the Canadian World Trade Analyzer dataset are actually comprised of country or regional groups. These are as follows.

1. "Belgium" is comprised of Belgium and Luxembourg.

2. "Czech Republic" is comprised of the Czech Republic and Slovakia.

3. "Ethiopia" is comprised of Ethiopia and Eritrea.

4. "Guinea-Bissau" is comprised of Guinea-Bissau, Cape Verde and Sao Tome and Principe.

5. "Indonesia" is comprised of Indonesia, East Timor and Macau (China).

6. "Russian Federation" is comprised of the Russian Federation, Armenia, Azerbaijan, Belarus, Estonia, Georgia, Kazakhstan, Kyrgyzstan, Latvia, Lithuania, Moldova, Tajikistan, Turkmenistan, Ukraine and Uzbekistan.

7. "South Africa" is comprised of South Africa, Botswana, Lesotho, Namibia and Swaziland.

8. "Yugoslavia" is comprised of Yugoslavia, Bosnia and Herzegovina, Croatia, Macedonia and Slovenia.

Thus our full sample is actually made up of 162 countries or regions, for which there are discrete data for 135. (No independent variables were constructed for East Timor and Sao Tome and Principe, so data on these only figure into the left-hand side of the trade model equations and are not counted in the 162). Certain independent variables could not be constructed additively and so were constructed in the following manner. The common border dummy equals 1 if a country has a common border with any country or region in the eight groups and 0 otherwise. The regional trade agreement dummy equals 1 if a country is in a regional trade agreement with any country or region in the eight groups and 0 otherwise. The landlocked dummy equals 1 if the entire country or region group is landlocked and 0 otherwise. The island dummy equals 1 if the entire country or region group is an island and 0 otherwise.

All indicators of FACB rights and democracy are constructed as weighted averages, using a country or region's economically active population as of 1995 as the weight. The exception is the dummy variable for FACB rights in EPZs, for which the value for the largest country or region in its group is taken. Whether measured by GDP (in current US dollars), population or land area, the largest country or region in its group is in all eight cases the country is that in quotation marks above. The distance between a country and the above country or region groups is taken as the distance from the geographic center of the largest country in its group. The bilateral exchange rate between a country and the above country or regional groups is taken that with the largest country in its group.

In addition, GDP data were missing for some countries in the above groups for some years. Since these were constructed additively for period averages, missing values were estimated with a linear time trend for Bosnia, Macedonia and Turkmenistan for GDP in 1993 (in current US dollars) and for Georgia and Tajikistan for 1993 and 1994 (in current US dollars and PPP). Data for GDP in PPP for Tajikistan were taken from World Development Indicators for 2000, as they were not available in the 2001 edition.

Regional breakdowns of total manufacturing exports as percentage shares (table 5.E) are based on all countries in the full sample, plus eight for which there are trade data but which drop out of the sample because of missing GDP data. These are Afghanistan, Cuba, Iraq, Liberia, Libya, Myanmar, North Korea and Somalia. These eight countries are not included in tables 3.B and 3.C, nor in the construction of "residual" versions of FACB indicators. 